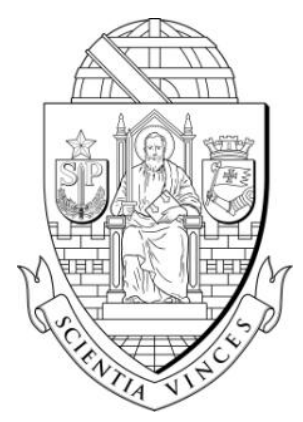

\author{
UNIVERSIDADE DE SÃO PAULO \\ ESCOLA DE COMUNICAÇÕES E ARTES \\ PROGRAMA DE PÓS-GRADUAÇÃO EM CIÊNCIA DA INFORMAÇÃO
}

\author{
LILIAN VIANA
}

\title{
BIBLIOTECAS ESCOLARES POLÍTICAS PÚBLICAS PARA A CRIAÇÃO DE POSSIBILIDADES
}




\section{LILIAN VIANA}

\section{BIBLIOTECAS ESCOLARES POLÍTICAS PÚBLICAS PARA A CRIAÇÃO DE POSSIBILIDADES}

Dissertação apresentada ao Programa de Pós-Graduação em Ciência da Informação da Escola de Comunicações e Artes da Universidade de São Paulo, como requisito para a obtenção do título de Mestre em Ciência da Informação.

Área de concentração: Cultura e informação

Orientadora: Profa. Dra. Ivete Pieruccini

\section{Versão corrigida}

(A versão original impressa encontra-se disponível na biblioteca da Escola de Comunicações e Artes da Universidade de São Paulo, assim como a versão original eletrônica pode ser acessada a partir da Biblioteca Digital de Teses e Dissertações da USP)

São Paulo 
Autorizo a reprodução e divulgação total ou parcial deste trabalho, por qualquer meio convencional ou eletrônico, para fins de estudo e pesquisa, desde que citada a fonte.

Catalogação na Publicação

Serviço de Biblioteca e Documentação

Escola de Comunicações e Artes da Universidade de São Paulo

Dados fornecidos pela autora

Viana, Lilian

Bibliotecas escolares: políticas públicas para a criação de possibilidades / Lilian Viana. - - São Paulo: L. Viana, 2014.

167 p.: il.

Dissertação (Mestrado) - Programa de Pós-Graduação em Ciência da Informação Escola de Comunicações e Artes/ Universidade de São Paulo.

Orientadora: Ivete Pieruccini

Bibliografia

1. Biblioteca escolar 2. Política pública 3. Lei federal n.12.244/10 4. Apropriação cultural 5. Informação e Educação I. Pieruccini, Ivete II. Título 
VIANA, Lilian

Bibliotecas escolares: políticas públicas para a criação de possibilidades

Dissertação apresentada à Escola de Comunicações e Artes da Universidade de São Paulo para obtenção do título de Mestre em Ciência da Informação

Aprovado em:

Banca Examinadora

Profa. Dra.: Instituição:

Julgamento: Assinatura:

Profa. Dra.: Instituição:

Julgamento: Assinatura:

Profa. Dra.: Instituição:

Julgamento: Assinatura: 


\section{AGRADECIMENTOS}

À professora Ivete Pieruccini, que com sua postura me ensinou que para ser mestre é preciso paciência, comprometimento, rigor, criticidade, criatividade e ética. Sou extremamente grata por sua presença rigorosa e amiga ao longo deste percurso.

À professora Lúcia Maciel Barbosa de Oliveira, por sua constante disposição em colaborar com críticas valiosas, questionamentos e indicações de leitura.

Ao professor Edmir Perrotti, por ter compartilhado saber e experiência em sala de aula e nas reuniões do grupo de pesquisa.

À professora Lucília Maria Abrahão e Sousa, pela leitura atenta e crítica.

Ao professor José Fernando Modesto da Silva, pela colaboração e atenção dispensada.

Ao Admir Ferro, Cláudia Sarro, Cristina Bisognini, Dalva Franceschetti, Jumara Bulha, Maurício Soares e Rosemeire da Silva por compartilharem comigo sua experiência, imprescindível para a concretização desta pesquisa. Muito obrigada!

À Nêmora Arlindo Rodrigues, Regina Celi Sousa e Profa. Bernadete Campello, pela solicitude com que me atenderam.

Ao Caio Batista da Silva, por toda gentileza e disposição em colaborar.

À Marina Macambyra, Olga Mendonça e Walber Lustosa, companheiros de trabalho que sempre estiveram abertos ao diálogo e negociações para que eu pudesse me dedicar à pesquisa.

A todos os amigos e colegas pelas inúmeras conversas sobre a pesquisa acadêmica.

À CAPES, pela concessão de bolsa de estudos.

Aos meus familiares, pelo incentivo constante.

Ao Danilo, companheiro da vida, pelo estímulo constante e por compreender minhas ausências.

A mãe, Helena, e pai, Benedito, por tudo, por terem me ensinado o valor da educação. 
Mas posso apreciar a força da ideia de que as pessoas devem ter a responsabilidade de desenvolver e mudar o mundo em que vivem [...]. Como pessoas que vivem - em um sentido amplo - juntas, não podemos escapar à noção de que os acontecimentos [...] que vemos à nossa volta são essencialmente problemas nossos. Eles são de responsabilidade nossa - independente de serem ou não de mais alguém. 


\section{RESUMO}

VIANA, Lilian. Bibliotecas escolares: políticas públicas para a criação de possibilidades. 2014. 167 p. Dissertação (Mestrado em Ciência da Informação) - Escola de Comunicações e Artes, Universidade de São Paulo, São Paulo, 2014.

Esta pesquisa partiu da atual situação da biblioteca escolar brasileira; instituição que, ainda quando existente, é marcada sobretudo por concepções centradas em apenas uma de suas características: uma coleção organizada de recursos informacionais. A questão ganha destaque no presente momento, com a emergência da Lei Federal $\mathrm{n}^{0} 12.244 / 10$, que determina a obrigatoriedade da criação de bibliotecas nas instituições de ensino nacionais e as define exclusivamente como um acervo, bastando, portanto, ações centradas na garantia do acesso à coleção disponibilizada pelas bibliotecas para o cumprimento da determinação oficial. A partir deste contexto, o estudo indica a necessidade do desenvolvimento de políticas públicas ocupadas não somente com a criação de bibliotecas escolares, mas principalmente com sua ressignificação na educação, garantindo que se ocupem com o direito de informar-se que crianças e jovens têm, apropriando-se de informação e cultura. Com o objetivo de conhecer e sistematizar categorias implicadas na implantação de políticas públicas para bibliotecas escolares, a pesquisa - de natureza qualitativa - contemplou uma abordagem de referencial teórico e de estudo exploratório - por meio de entrevistas semiestruturadas - sobre a implantação da política pública municipal levada a efeito na cidade de São Bernardo do Campo (SP), que teve como fruto a Rede Escolar de Bibliotecas Interativas (REBI), concebida a partir do paradigma da apropriação cultural. Como resultado, foram sistematizadas categorias a serem consideradas numa política pública voltada à criação, ressignificação e consolidação da biblioteca escolar em nosso país.

Palavras-chave: Biblioteca escolar. Políticas públicas. Informação e Educação. Lei Federal n ${ }^{\circ}$ 12.244/10. Apropriação Cultural. 


\begin{abstract}
VIANA, Lilian. Bibliotecas escolares: políticas públicas para a criação de possibilidades. 2014. 167 p. Dissertação (Mestrado em Ciência da Informação) - Escola de Comunicações e Artes, Universidade de São Paulo, São Paulo, 2014.
\end{abstract}

This research was based on the situation of Brazilian school libraries; still scarce in the educational environment and when they exist are usually only a collection of book; an organized collection of information. The issue takes on more relevance with the creation of Brazilian federal law $n^{0} 12.244 / 10$ which mandates the creation of libraries in all national educational institutions and defines them solely as a collection of material. Therefore, efforts focused only on providing access to library materials are sufficient to fulfill the schools obligation under the law. In this context, the study recommends the development of public policy focused not only on the creation of school libraries but also, and crucially, on redefining them, ensuring that they will be focused not only on the right to access information, but also the right to know how to access and use it. Aiming to understand and define criteria for the implementation of public policy for school libraries, this qualitative research included a theoretical approach and also an exploratory study - through semi-structured interviews on the implementation of the municipal public policy carried out in São Bernardo do Campo (SP), which led to the creation of Rede Escolar de Bibliotecas Interativas, a network of libraries based on the concept of apropriação cultural (Portuguese term that means the construction of meaning for the use of the informational/cultural Center). As a result, the criteria to be considered in public policy aimed at the creation, redefinition and consolidation of school libraries in Brazil have been defined.

Keywords: School library. Public police. Information and Education. Brazilian federal Law $\mathrm{n}^{\mathrm{o}}$ $12.244 / 10$. 


\section{LISTA DE SIGLAS}

\begin{tabular}{|c|c|}
\hline APM & Associação de Pais e Mestres \\
\hline BEI & Biblioteca Escolar Interativa \\
\hline CFB & Conselho Federal de Biblioteconomia \\
\hline CRB8 & Conselho Regional de Biblioteconomia $8^{\circ}$ Região \\
\hline CRD/ECA/USD & Departamento de Biblioteconomia e Documentação da Escola de \\
\hline 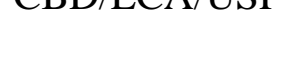 & Comunicações e Artes da Universidade de São Paulo \\
\hline FAPESP & Fundação de Amparo à Pesquisa do Estado de São Paulo \\
\hline INL & Instituto Nacional do Livro \\
\hline LDB & Lei de Diretrizes e Bases da Educação Nacional \\
\hline MEC & Ministério da Educação \\
\hline MES & Ministério dos Negócios da Educação e Saúde Pública \\
\hline ONG & Organização Não-Governamental \\
\hline PABE & Professora de Apoio a Biblioteca Escolar \\
\hline PBE & Programa Biblioteca e Educação \\
\hline PNBE & Programa Nacional Biblioteca da Escola \\
\hline PNLD & Programa Nacional do Livro Didático \\
\hline PROESI & Programa Serviços de Informação em Educação \\
\hline REBI & Rede Escolar de Bibliotecas Interativas \\
\hline SBC & São Bernardo do Campo \\
\hline SBE & Seção de Biblioteca Escolar \\
\hline SEC & Secretária de Educação e Cultura \\
\hline
\end{tabular}




\section{SUMÁRIO}

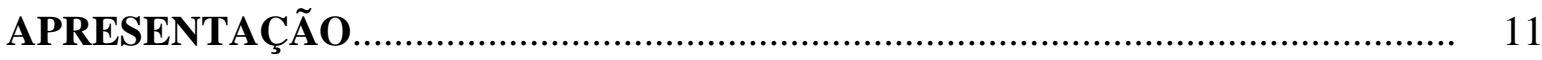

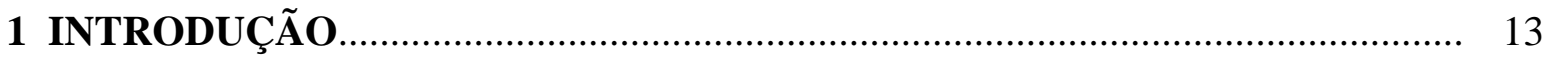

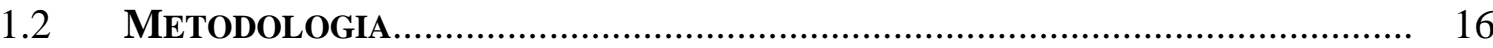

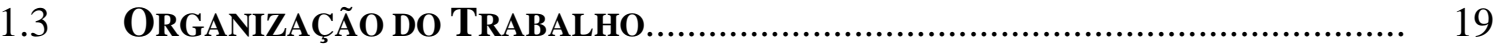

2 BIBLIOTECA ESCOLAR BRASILEIRA: ARQUEOLOGIA DO PROBLEMA 21

2.1 BIBLIOTECA E EDUCAÇÃO NO BRASIL ........................................................ 22

2.1.1 Brasil Colônia: Livros e Bibliotecas a Serviço da Ordem Simbólica................ 22

2.1.2 Brasil Independente: Um Reino Sem Escolas e Bibliotecas............................ 26

2.1.3 Brasil República: Escola Nova e Bibliotecas................................................. 28

2.1.4 A República Nova: Uma Política para a Educação e para os Livros................. 32

2.2 BRASIL CONTEMPORÂNEO: BIBLIOTECA ESCOLAR, INFORMAÇÃO E EDUCAÇÃO........................................................................................ 36

2.2.1 Biblioteca Escolar Brasileira: Do Passado ao Presente, Qual o Futuro?........... 40

3 POLÍTICA: PELA CRIAÇÃO DE POSSIBILIDADES...................................... 45

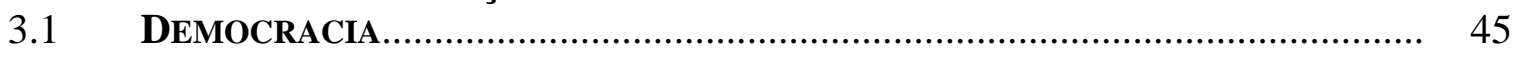

3.2 Política Pública: Conceitos E Definições.......................................... 48

3.2.1 Política de Governo e Política de Estado...................................................... 53

3.3 ESTAdO E SOCIEDAdE CIVIL ................................................................. 55

3.4 O Sujeito e a ParticipaÇão Política...................................................... 58

3.5 O Ciclo da Política Pública..................................................................... 60

3.5.1 Reconhecimento do Problema e Delimitação da Questão............................... 62

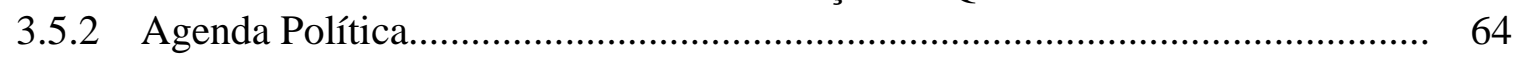

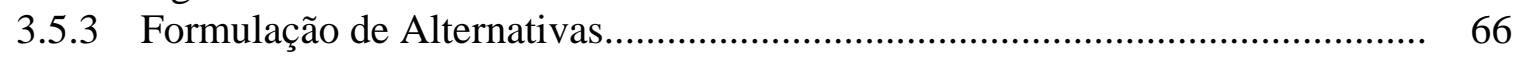

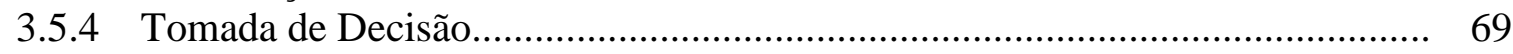

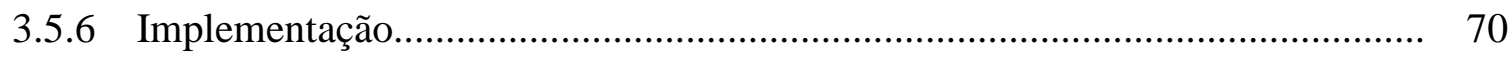

3.5.7 Monitoramento e Avaliação........................................................................ 71

4 IMPLANTAÇÃO DE BIBLIOTECAS ESCOLARES: O PARADIGMA DA

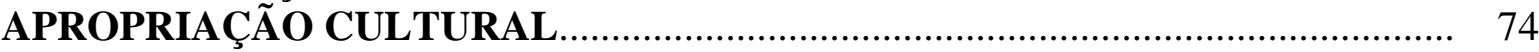

\section{POLÍTICA PÚBLICA PARA BIBLIOTECAS ESCOLARES: O SABER DE}

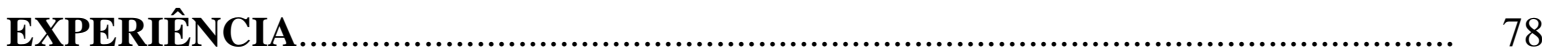

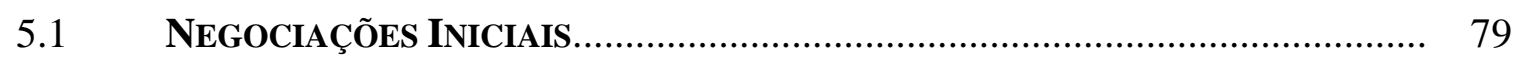

5.1.1 Compra de Livros: a Clássica Alternativa ao Problema da Leitura............... 79

5.1.2 O Diálogo Redefinindo Percursos............................................................. 80

5.1.3 Busca por Modelos.......................................................................... 82

5.1.4 Busca por Parcerias Inter e Transdisciplinares......................................... 84

5.1.5 A Voz do Campo Científico................................................................... 85

5.1.6 O Protagonismo dos Profissionais............................................................ 88

5.1.7 Vontade Política......................................................................................... 90

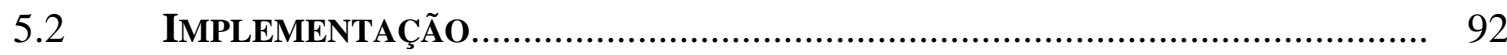


5.2.1 Os Protocolos Explícitos e Implícitos.

5.2.2 Resultados Concretos e Inovadores: a Rede Escolar de Bibliotecas

Interativas

94

5.2.2.1 Arquitetura, mobiliário e equipamentos................................................. 96

5.2.2.2 Repertório informacional e linguagem documentária.................................. 99

5.2.2.3 Práticas de gestão, pedagógicas e culturais................................................ 101

5.2.3 Comunicação de Intenções e Resultados.................................................. 103

5.2.4 Cenário Favorável................................................................................. 105

5.2.4.1 O tempo para continuidade das ações...................................................... 106

5.2.4.2 Políticas amplas no contexto da educação................................................ 107

5.2.5 Quadro Profissional: Identidade na Diferença.............................................. 108

5.2.5.1 Bibliotecários: um novo papel............................................................... 109

5.2.5.2 Orientadoras pedagógicas: gestão compartilhada......................................... 110

5.2.5.3 Professoras de Apoio à Biblioteca Escolar (PABE): criação de novos postos 111

5.2.5.4 Professoras de Apoio à Biblioteca Escolar - função Referência (PABEs

Referência): ampliação de estruturas........................................................... 113

5.2.6 Formação dos Profissionais ................................................................ 114

5.2.6.1 Formação dos profissionais da Seção de Biblioteca Escolar........................... 115

5.2.6.1.1 Bibliotecárias: ressignificação da experiência profissional............................. 115

5.2.6.1.2 Professoras de Apoio à Biblioteca Escolar e Orientadoras pedagógicas........ 117

5.2.6.2 Formação dos professores, diretores e coordenadores de escolas................... 119

5.2.7 Instâncias de Negociação: Consolidar o Papel da Biblioteca na

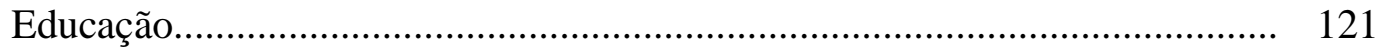

5.2.7.1 Primeiro nível de negociação: PABE............................................................ 122

5.2.7.2 Segundo nível de negociação: PABE Referência........................................... 125

5.2.7.3 Terceiro nível de negociação: chefe da Seção de Biblioteca Escolar............. 127

5.2.8 O Papel da Comunidade na Política Pública: Tempo, Informação,

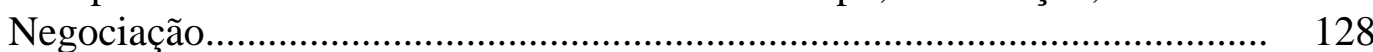

5.3 Permanência da Política Pública..................................................... 132

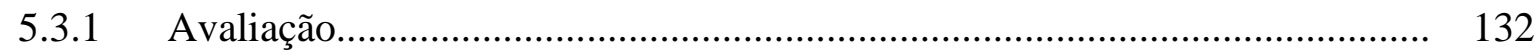

5.3.2 Consolidação de Ações e Investimentos...................................................... 134

5.3.3 Continuidade: a Política Pública Para Além dos Sujeitos.............................. 136

5.3.4 Manutenção da Política Pública: o Diálogo Não Pode Parar.......................... 141

6 CONSIDERAÇÕES FINAIS: POR UMA NOVA BIBLIOTECA ESCOLAR..... 146

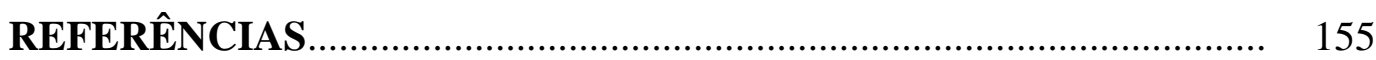

APÊNDICES ......................................................................... 161

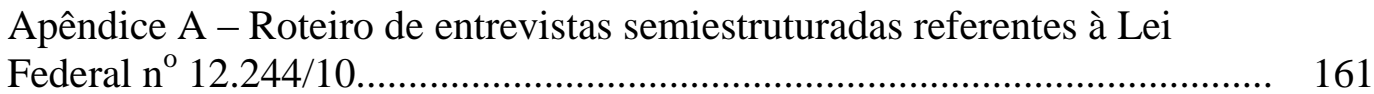

Apêndice B - Redes de bibliotecas escolares identificadas no território nacional.......................................................................................... 162

Apêndice C - Roteiro de entrevistas semiestruturadas referentes à REBI..... 163

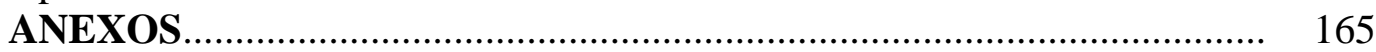

Anexo A - Lei Federal ${ }^{0}$ 12.244, de 24 de maio de 2010.......................... 165

Anexo B - Projeto de Lei $n^{\circ} 1.831$, de 2003 ................................................. 166 


\section{APRESENTAÇÃO}

O término de minha graduação em Biblioteconomia foi marcado pela elaboração de uma monografia final acerca de políticas culturais para bibliotecas públicas. Já naquela época eu me inquietava, pensando que esforços isolados dificilmente conseguiriam promover transformações na ampla esfera social. Para mim era certa a importância de compreender o papel do Estado como agente de mudanças, pois enxergava nas políticas públicas um caminho para alterar realidades.

O início de minha carreira profissional como bibliotecária foi marcado por uma experiência que me colocou, novamente, em face de tais inquietações. Tive a oportunidade de trabalhar em uma biblioteca pública, acompanhando inclusive os momentos que antecederam sua inauguração. A biblioteca era anunciada pelo governo como iniciativa inovadora; foram muitas as equipes de reportagem que fizeram matérias, e diversos os profissionais, sobretudo bibliotecários, que foram visitá-la, desejosos por conhecer o fruto da ação política.

Entretanto, a experiência por detrás dos bastidores revelou-se, para mim, uma iniciativa problemática. A biblioteca, então aberta, desvelava a ausência de planejamento, demonstrando que os esforços se concentraram, sobretudo, em construir um espaço físico repleto de livros e computadores e que se destacava, exclusivamente, pela qualidade de seus recursos materiais. Não haviam sido planejadas ações a serem desenvolvidas naquela biblioteca, a preocupação havia sido somente com o espaço e seus recursos.

Assim, em minha rotina de trabalho deparei-me com uma imensa quantidade de pessoas que utilizavam aquele espaço, em sua maioria moradores de rua, homens e mulheres que viviam em albergues e iam até lá para passar o dia. Permaneciam por longas horas em frente aos computadores, assistindo a vídeos no Youtube, ouvindo músicas, e navegando em redes sociais, numa ação repetitiva que em pouco contribuía para transformar suas vidas. Diante deste cenário problemático, permeado pelo discurso 'melhor isso do que estar na rua roubando', emergia em mim a sensação de incompetência.

Foi a urgência por respostas, inflada por esta experiência, que culminou na minha inscrição como aluna especial numa disciplina da pós-graduação em Ciência da Informação na ECA-USP. As discussões presentes naquela disciplina foram definitivas para que eu tentasse ingressar no mestrado. 
Em meio ao percurso de estudos para aprovação no mestrado, deparei-me refletindo sobre uma questão que vinha sendo discutida no campo da Biblioteconomia: a Lei Federal $\mathrm{n}^{\circ}$ 12.244/10, que determina a obrigatoriedade da existência de bibliotecas em todas as escolas do país no prazo de 10 anos (2010-2020). O texto oficial era saudado por muitos profissionais, certos de que ali estava a iniciativa capaz de fazer as bibliotecas se concretizarem na realidade educacional brasileira, ainda bastante carente destes organismos. No entanto, a situação revelava para mim outras nuances. Coloquei-me a refletir sobre a pertinência de um texto legislativo que determina a criação de bibliotecas escolares sem, todavia, ser acompanhado de ações políticas concretas para implantá-las. Mais que isso, vislumbrei nesta situação o risco de ser implantada uma política pública para a construção de bibliotecas tal qual a da minha experiência profissional: espaços equipados e dotados de recursos informacionais, porém esvaziados de ações que, efetivamente, contribuíssem para transformar a vida das pessoas.

Anunciava-se assim a pertinência de estudar as políticas públicas como um caminho para a criação de bibliotecas escolares, todavia, a partir de concepções alinhadas com a problemática do quadro informacional contemporâneo. Estava nítida para mim a relevância de bibliotecas escolares que não se limitassem a perspectiva do direito de acesso, mas que, sobretudo, se ocupassem com o direito de saber informar-se, de apropriar-se de informação e cultura. Nesse sentido, encarei a política pública como um caminho para que as bibliotecas escolares efetivamente fizessem parte de nossa realidade.

Foram essas inquietações que deram origem a presente dissertação de mestrado, resultado de minha busca junto à ciência por respostas, mas também, por novas questões e que, sinceramente espero possa contribuir em alguma medida para transformar a situação da biblioteca escolar brasileira. 


\section{INTRODUÇÃO}

No cenário europeu renascentista, a biblioteca passa por um processo de laicização cada vez mais nítido. Do final do século XVI ao momento presente, sua história assentou-se, gradativa e simultaneamente, em transformações que, além da laicização, incluíram outras características fundamentais: democratização, especialização e socialização (MARTINS, 1996, p. 323-325).

No âmbito da especialização, que implicou o desenvolvimento de diferentes tipos de bibliotecas com objetivos específicos, destaca-se o surgimento da biblioteca escolar, em decorrência da necessidade de conservação dos materiais utilizados em aula pelos professores.

Em 1860, especificamente no contexto francês, os prefeitos eram orientados a instalar "uma pequena biblioteca-armário, destinada à conservação dos livros, dos cadernos e dos quadros impressos para uso da escola" ". E para estimular os indecisos, acrescentava que "todo projeto de construção [...] de escola, para cuja execução se solicite auxílio, deverá ser acompanhado de um orçamento especial de despesas relativas ao mobiliário escolar, no qual será incluída, prioritariamente, uma biblioteca". Com efeito, a criação da biblioteca-armário nas escolas tinha o intuito de reunir e preservar os livros, com vistas à ampliação de seu uso pelos alunos (HEBRARD, 2009, p.7-9). Portanto, o caráter democrático da biblioteca escolar circunscrevia-se à garantia de acesso aos livros pelos estudantes.

Já no contexto brasileiro, a origem da biblioteca escolar relaciona-se ao período colonial, em que os livros e a educação estavam sob tutela da Igreja, sendo base para o ensino sustentado na propagação da fé. Ainda em meados do século XIX, mesmo com a laicização do ensino, não são identificadas iniciativas oficiais, no âmbito nacional, em torno da biblioteca escolar, mas apenas ações isoladas que com o passar do tempo, e apesar dos esforços, perderam forças (MORAES, 1979, p. 5).

Mesmo na atualidade, a biblioteca escolar não é, efetivamente, tida como relevante no Brasil, haja vista a carência destes organismos na cena educacional e sua concepção, que não difere muito da biblioteca-armário, resumindo-se a um acervo organizado de livros.

\footnotetext{
${ }^{1}$ Circular do Ministro da Instrução Pública e dos Cultos aos Governadores, de 31 de maio de 1860, relativa ao estabelecimento de bibliotecas escolares nas escolares primárias públicas. Citado por Hebrard (2009, p. 7).
} 
Se em seus primórdios a biblioteca escolar caracterizou-se como uma instituição democrática, na medida em que ampliava o acesso aos recursos informacionais, no momento atual tal oferta, por si só, não mais se alinha à ideia democrática. No cenário informacional contemporâneo - marcado pelo desenvolvimento tecnológico -, os fluxos da informação, bem como sua manipulação, adquirem importância crescente para a sociedade. Identificar, acessar, armazenar, processar e apropriar-se das informações são ações que, cada vez mais, determinam a relação das pessoas com o mundo, assim como a influência que neste exercem.

Portanto, para o desenvolvimento de bibliotecas escolares efetivamente democráticas, não basta que informações estejam ao alcance das mãos. É preciso uma perspectiva que, para além do direito de acesso, contemple o direito de saber informar-se, de que os sujeitos apropriem-se de informação e cultura em perspectiva crítica e criativa, comprometida com a construção de um futuro comum a todos. É neste âmbito que o potencial da biblioteca se revelará na educação, se ocupando da formação de pessoas que desempenhem o papel criativo, e não somente de consumidoras de informação.

Ações centradas no direito de acesso à informação, ou seja, que garantam a distribuição de recursos informacionais e também o acesso a informações disponíveis online, precisam ser superadas por perspectivas que comportem o direito de saber informar-se. Assim, a partir de Perrotti e Pieruccini (2008), são demandadas iniciativas que compreendam o desenvolvimento de saberes informacionais, que reúnem o conjunto de habilidades, competências e atitudes dos sujeitos face ao universo informacional, para que busquem, selecionem, analisem e apropriem-se das informações de forma crítica, conhecendo o que é o conhecimento, com seus riscos de erro e ilusão, conforme reivindicado por Morin (2000).

Se, por um lado, tal perspectiva é urgente, por outro, no cenário nacional ainda predominam iniciativas governamentais circunscritas à distribuição de recursos informacionais às escolas; evidência de que, no contexto brasileiro, o percurso do armário à biblioteca escolar ainda está por ser feito.

Em meio a essa conjuntura, no ano de 2010 despontou iniciativa federal em torno das bibliotecas escolares brasileiras: a Lei Federal $\mathrm{n}^{\mathrm{o}} 12.244$ (Anexo A), que dispõe sobre a universalização das bibliotecas nas instituições de ensino. O texto legislativo estabelece o prazo máximo de dez anos para que todas as escolas tenham bibliotecas. Portanto, 2020 é a data limite para que estejam de acordo com a disposição legal, que define biblioteca escolar como "a coleção de livros, materiais videográficos e documentos registrados em qualquer 
suporte destinados à consulta, pesquisa, estudo ou leitura", determinando, ainda, a obrigatoriedade de um acervo de livros na biblioteca de "no mínimo, um título para cada aluno matriculado", bem como o respeito à profissão de bibliotecário (BRASIL, 2010).

O texto legislativo demonstra conceber a biblioteca escolar de acordo com conceitos historicamente arraigados em nossa sociedade, confinando este importante dispositivo a apenas uma de suas características: uma coleção de recursos informacionais.

A definição dá margem a questionar em que medida a multiplicação de bibliotecas escolares, entendidas como acervo, contribuirá para a formação de crianças e jovens, face ao cenário informacional contemporâneo. Serão organismos voltados ao diálogo e à construção do conhecimento, ou, estarão circunscritas a concepções de transmissão e recepção? Será positiva uma iniciativa centrada na difusão de informações, deixando de lado ações que garantam o direito de saber informar-se, de apropriar-se de informação e cultura?

Por sua vez, a carência de ações efetivas, empreendidas pelo poder público em torno da biblioteca escolar - transcorridos mais de quatro anos da sanção da lei -, sinaliza para a redução de sua complexidade, na medida em que apenas criar espaços com livros, supervisionados por um profissional, é suficiente para atender os preceitos legais.

Para que a biblioteca escolar saia do texto, e faça parte de nossa realidade, é fundamental que o poder público empreenda ações, todavia, assumindo que não se trata simplesmente de criar espaços e dotá-los com livros e outros recursos. É preciso o desenvolvimento de bibliotecas escolares a partir de outros referenciais, em outros termos; faz-se necessária uma política pública que assuma a importante missão de ressignificar a biblioteca na educação. A tarefa é certamente complexa, na medida em que compreende a ressignificação de um dispositivo em contexto educacional ainda marcado pelo transmissivismo.

Diante deste árido panorama se deu a presente pesquisa. Tendo como objetivo central identificar e descrever categorias teórico-metodológicas que possam contribuir para a formulação de políticas públicas para bibliotecas escolares no Brasil, o estudo insere-se no campo da Ciência da Informação, mais especificamente na Infoeducação, em cujo âmbito a biblioteca escolar ocupa papel de destaque, como categoria ligada aos processos de apropriação de informação e cultura. 


\subsection{METOdologia}

A metodologia adotada para o trabalho contemplou dois eixos:

\section{A) Pesquisa bibliográfica}

Inicialmente foi empreendida pesquisa de referencial teórico em torno de conceitoschave para a dissertação. Assim, "política pública", "política" e "democracia" foram discutidos, tendo por base Nogueira (2004), Lefort (1991), Arendt (1997 e 2005), Touraine (1996), De Certeau (1995), Theodoulou (1995) e Deubel (2007). Enquanto isso, as reflexões em torno de "educação", "biblioteca escolar", "protagonismo cultural" e "apropriação cultural" foram empreendidas considerando sua inscrição no campo teórico da Infoeducação ${ }^{2}$, e tiveram embasamento conceitual em Perrotti e Pieruccini (2008; 2013), Charlot (2008), Rancière (2011), Morin (2000), Gadotti (2012) e Aranha (1989).

A busca de referencial teórico foi realizada nos bancos de dados bibliográficos da USP, UNESP e UNICAMP, Portal CAPES, bases de dados da Ebsco e Jstor, bem como no Google e Google acadêmico.

\section{B) Pesquisa de campo}

A pesquisa de campo foi desenvolvida a partir de metodologia qualitativa, contemplando a coleta de depoimentos e a análise das informações obtidas de forma indutiva, ou seja, abstrações foram construídas à medida que os dados foram colhidos. A extrema relevância dos significados foi uma constante, portanto, buscamos compreender palavras em seus contextos tendo em vista conhecer um processo e não somente seus resultados (BOGDAN; BIKLEN, 2010, p.47-48). Nesse sentido, foram compreendidas duas dimensões:

\section{- O surgimento da Lei Federal $n^{0}$ 12.244/2010}

\footnotetext{
${ }^{2}$ A Infoeducação é "área de estudo situada nos desvãos das Ciências da Informação e da Educação, voltada à compreensão das conexões existentes entre apropriação simbólica e dispositivos culturais, como condição à sistematização de referências teóricas e metodológicas necessárias ao desenvolvimento dinâmico e articulado de aprendizagens e de dispositivos informacionais, compatíveis com demandas crescentes de protagonismo cultural, bem como de produção científica, constituída sob novas óticas, nas chamadas Sociedades do Conhecimento" (PERROTTI, PIERUCCINI, 2008).
} 
Realizou-se coleta de informações tendo em vista conhecer as representações dos sujeitos diretamente implicados em sua criação e desdobramentos. Foram elencados políticos envolvidos com a questão e, também, representantes de grupo de interesse em torno da biblioteca escolar, que se mobilizaram para que a lei fosse criada. Foram eles: senador Cristovam Buarque; ex-deputado federal Lobbe Neto; deputado federal Sandes Júnior; Regina Celi Sousa - atual presidente do Conselho Federal de Biblioteconomia (CFB); Nêmora Arlindo Rodrigues - ex-presidente do CFB; José Fernando Modesto da Silva - ex-presidente do Conselho Regional de Biblioteconomia $8^{a}$ Região (CRB8) e CFB, atualmente professor na Universidade de São Paulo ${ }^{3}$.

O retorno de todos os interpelados foi apenas parcial, tendo sido marcante o silêncio dos que representam a classe política ${ }^{4}$. Assim, esta etapa da pesquisa contou com o discurso de sujeitos da classe profissional bibliotecária - Regina Celi Sousa e Nêmora Arlindo Rodrigues - bem como de um professor universitário engajado na questão - José Fernando Modesto da Silva.

Em face de questões operacionais - como disponibilidade de agenda e distância geográfica -, o instrumento utilizado para a coleta de informações junto às representantes da categoria profissional foi o questionário aberto, que, conforme Selltiz et al. (1975), confere grande peso à descrição verbal do sujeito para obter informações quanto a experiências e situações por ele vivenciadas. Enquanto isso, com José Fernando Modesto da Silva foi realizada entrevista semiestruturada (ver questões no Apêndice A).

\section{- Investigação acerca da implantação de política pública para criação de rede de} bibliotecas escolares

O levantamento de redes de bibliotecas escolares existentes no território nacional (ver listagem das redes no Apêndice B) constituiu etapa preliminar da investigação, buscando-se identificar, dentre elas, quais se adequariam ao escopo e possibilidades de abordagem. A

\footnotetext{
${ }^{3}$ Lobbe Neto foi deputado federal no período de 2002 a 2010, a gestão de Regina Celi Sousa no CFB teve início em 2013, Nêmora Arlindo Rodrigues foi presidente do CFB entre 2006 e 2012, e José Fernando Modesto da Silva presidiu o CRB8 entre 1991 e 1993, tendo presidido o CFB no período de 2000 a 2002.

4 Nos dias 21/11/2013 e 14/01/2014 foram enviados e-mails ao senador Cristovam Buarque (cristovam@senador.leg.br) solicitando que respondesse questões sobre o tema. No dia 21/11/2013 foi enviado e-mail ao ex-deputado Lobbe Neto (lobbe@lobbe.com.br) e também ao deputado federal Sandes Junior (dep.sandesjunior@camara.gov.br). Além disso, foi tentado contato com Sandes Júnior por meio do site da Câmara dos deputados, a partir da opção 'Fale com o deputado'.
} 
opção recaiu sobre a Rede Escolar de Bibliotecas Interativas (REBI) da cidade de São Bernardo do Campo (SBC), situada na Grande São Paulo.

A opção pela REBI se deu por razões diversas, dentre as quais: a concepção de biblioteca escolar inscrita nos primórdios da ação política; o contato da pesquisadora com ações de formação dos quadros profissionais da rede, desenvolvidas no período de 2011 a 2012; a participação direta da professora orientadora na política pública; a constatação da permanência da política (existente desde 1999); a viabilidade de deslocamento da pesquisadora até São Bernardo do Campo. Tais fatores foram determinantes para tal escolha, pois o contato direto com a ação permitiu o alargamento da compreensão sobre o corpus e, consequentemente, enriqueceu a análise das informações coletadas.

A REBI surgiu em 1999, a partir de uma parceria entre a gestão municipal e o Programa Serviços de Informação em Educação (PROESI) - do Departamento de Biblioteconomia e Documentação da Escola de Comunicações e Artes da Universidade de São Paulo (CBD/ECA/USP) -, sob a coordenação geral do Prof. Dr. Edmir Perrotti, firmada por meio de convênio de cooperação técnico-acadêmica.

- Coleta de dados:

As informações foram colhidas a partir de entrevistas semiestruturadas, sem delimitação inicial de número de sujeitos, pois conforme Chamon e Chamon alertam (2007, p.8), “impor um número mínimo de sujeitos na pesquisa não é compatível com os fundamentos da pesquisa qualitativa”.

Os sujeitos foram selecionados dentre aqueles que desempenharam funções distintas na experiência em foco. O objetivo foi apreender pontos de vista diversos sobre a política pública, considerando os vários aspectos implicados. As entrevistas semiestruturadas tiveram por base um roteiro, relacionado ao objetivo desta pesquisa (Apêndice C).

A busca de sujeitos implicados na ação política se deu por método de rede, a partir de indicações de nomes entre os primeiros sujeitos abordados. A princípio, foram entrevistadas duas pessoas que participaram da implantação da REBI $^{5}$ e, então, começou a ser revelado um universo de possíveis sujeitos a serem entrevistados. Após análise quanto ao papel

\footnotetext{
${ }^{5}$ Estes primeiros contatos foram fornecidos pela Profa. Dra. Ivete Pieruccini, que à época da implantação da REBI era pesquisadora do PROESI ECA-USP, tendo participado das atividades de formação dos quadros profissionais da Rede, conforme será visto em capítulo específico.
} 
desempenhado por cada pessoa indicada, foi delimitado o quadro de sujeitos para entrevistas. Por fim, chegou-se ao total de sete entrevistados, conforme quadro a seguir:

\begin{tabular}{|l|l|}
\hline Entrevistado & Perfil \\
\hline Maurício Soares & $\begin{array}{l}\text { Prefeito de São Bernardo do Campo no período } \\
\text { de 1997 a 2003. Responsável pela } \\
\text { implementação da política pública em } \\
\text { discussão. }\end{array}$ \\
\hline Admir Donizetti Ferro & $\begin{array}{l}\text { Secretário de Educação e Cultura de São } \\
\text { Bernardo do Campo no período de 1997 a 2008. }\end{array}$ \\
\hline Edmir Perrotti & $\begin{array}{l}\text { Mentor intelectual e assessor da implantação da } \\
\text { REBI. }\end{array}$ \\
\hline Cláudia Sarro & $\begin{array}{l}\text { Professora de Apoio à Biblioteca Escolar - } \\
\text { Referência. }\end{array}$ \\
\hline Jumara Bulha & $\begin{array}{l}\text { Chefe da Divisão de Programas Educacionais } \\
\text { da Secretaria de Educação e Cultura de São } \\
\text { Bernardo do Campo. }\end{array}$ \\
\hline Cristina Bisognini & $\begin{array}{l}\text { Chefe da Seção de Biblioteca escolar (SBE) da } \\
\text { Secretaria de Educação e Cultura de São } \\
\text { Bernardo do Campo. }\end{array}$ \\
\hline Dalva Franceschetti & $\begin{array}{l}\text { Bibliotecária da Seção de Biblioteca escolar e, } \\
\text { posteriormente, chefe da Seção de Biblioteca } \\
\text { escolar da Secretaria de Educação e Cultura de } \\
\text { São Bernardo do Campo. }\end{array}$ \\
\hline
\end{tabular}

\subsection{OrganizaÇão do Trabalho}

Além da introdução, a dissertação estrutura-se em quatro capítulos:

O primeiro capítulo trata dos elementos que marcaram a história da biblioteca escolar em nosso país e de suas marcas no presente, além da atual conjuntura da biblioteca escolar na esfera legislativa brasileira, com a Lei Federal nº 12.244/10.

O segundo capítulo apresenta referencial teórico acerca do tema políticas públicas, tendo em vista desvendar seus elementos constitutivos, apontando a ação política como caminho para transformar realidades.

No terceiro capítulo discute-se o paradigma da apropriação cultural como norte ao desenvolvimento de bibliotecas escolares, questão em foco na pesquisa. 
O quarto capítulo refere-se ao processo de implantação da REBI, política pública municipal para bibliotecas escolares em análise e corpus desta investigação.

As considerações finais tratam das sínteses e discussão das inter-relações entre os temas abordados ao longo da dissertação. 


\section{BIBLIOTECA ESCOLAR BRASILEIRA: ARQUEOLOGIA DO PROBLEMA}

Toda biblioteca dissimula uma concepção implícita da cultura, do saber e da memória, bem como da função que lhe cabe na sociedade de nosso tempo.

$\operatorname{Jacob}(2008, p .10)$.

Os primórdios das bibliotecas remontam à Mesopotâmia Antiga, em que tais organismos conservavam as placas de argila seca marcadas com a escrita cuneiforme. Vinculavam-se, pois, à escrita, sendo representativas de um processo em que as sociedades deixavam de depender exclusivamente da transmissão oral da memória. Já na Grécia Antiga as bibliotecas atenienses respondiam mais a uma necessidade de intelectuais do que a um projeto científico e político (GOULEMOT, 2011, p.26-27). Na Idade Média, relacionavam-se à Igreja, responsável por guardar e preservar o conhecimento e, com a Renascença, começaram a adquirir outro perfil; não mais restritas aos monastérios e conventos, num processo de laicização cada vez mais consistente, vincularam-se ao desenvolvimento de instituições escolares, como as universidades. Com isso, gradativamente a sociedade passou a dispor de novos espaços para a conservação e circulação de livros.

Em meio às transformações, tem-se a segmentação em distintos tipos de bibliotecas, voltadas a diferentes parcelas da sociedade e com objetivos específicos. Dentre os modelos, interessa-nos compreender as bibliotecas escolares, especificamente no contexto brasileiro, admitindo-se que tiveram seu papel construído de acordo com as distintas políticas implementadas no campo da educação, o qual se insere no amplo contexto histórico e social.

Nesse sentido, a certeza de que as bibliotecas escolares conservam lembranças de tempos pretéritos e talvez mesmo de ideais que não chegaram a ser concretizados, coloca-nos face à relevância de investigar momentos de destaque da trajetória desta instituição, especificamente a partir de ações do poder público, tendo em vista escavar no passado elementos que nos auxiliem a compreender contextos que dizem respeito ao objeto desta pesquisa.

Envolta em um emaranhado de ações e inações, vozes esparsas e silêncios, a biblioteca escolar no Brasil é mais sonho que realidade. Assim, é instituição marginal que ainda não encontrou espaço na cena educacional para desenvolver-se enquanto ambiente de apropriação 
cultural, e consequente construção de conhecimento. Todavia, investimentos neste sentido são deveras complexos, já que nossas escolas - microcosmos da sociedade brasileira - mais parecem atuar no sentido de perpetuar desigualdades, ficando isentas da preocupação com a formação de sujeitos críticos.

Assim, face ao convite imperativo "Decifra-me ou te devoro!", deu-se a elaboração deste capítulo que, longe de intentar um histórico, busca conhecer momentos determinantes à atual configuração da biblioteca escolar brasileira.

\subsection{BiblioteCA E EdUCAÇão No BraSIL}

\subsubsection{Brasil Colônia: Livros e Bibliotecas a Serviço da Ordem Simbólica}

Com o intuito de desenvolver um trabalho missionário e pedagógico, as metrópoles europeias enviam religiosos a suas colônias; estes têm como objetivo primeiro converter os indígenas e impedir que os colonos se desviem da fé católica.

Em terras brasileiras a história não é diferente e, em 1549, quando Tomé de Sousa primeiro governador-geral - aqui aporta, vem acompanhado de jesuítas que, chefiados por Manuel da Nóbrega, chegam com seus livros. A importância conferida à instrução é visível, pois, apenas quinze dias após sua vinda, os missionários põem em funcionamento, na cidade de Salvador, uma escola para o ensino das primeiras letras. O processo de desenvolvimento de escolas elementares, secundárias, seminários e missões, ocupados com a catequese de índios, educação dos filhos dos colonos e formação de novos sacerdotes teve por base o controle da fé e moral dos habitantes da nova terra (ARANHA, 1989, p.119).

O que estava em pauta não era uma questão meramente religiosa, mas, sim, o emprego da ideologia cristã para auxiliar na garantia da unidade política, por meio da conformação de pensamentos à fé católica. Nesse sentido, a atividade missionária foi fundamental à dominação metropolitana e a educação assumiu papel de agente colonizador. E, acreditando em sua superioridade, esse colonizador impôs ao povo outra língua, outro Deus e outra moral. Assim, enquanto Portugal apropriou-se das riquezas naturais, a Igreja empreendeu a 
expropriação cultural, forma de poder e de imposição que consiste na "perda de controle sobre os recursos e as decisões culturais próprios” (TEIXEIRA COELHO 2004, p.173). Neste processo impositivo, com vistas à organização de novos sistemas simbólicos, a informação e o conhecimento foram poderosos instrumentos.

Em tal contexto, são criadas bibliotecas vinculadas às escolas e, num primeiro momento, estas reuniam filhos de índios e colonos. Progressivamente, a educação jesuítica promoveu a separação entre aqueles que seriam apenas catequizados e os que seriam instruídos. Portanto, enquanto ao índio era simplesmente imposto o ideal cristão, aos filhos dos colonos era fornecida educação que ia além do aprendizado da leitura e da escrita. Neste processo, as bibliotecas jesuíticas, até a segunda metade do século XVIII, deram base à formação intelectual dos jovens brasileiros, sendo que os mais abastados iriam completar seus estudos em Portugal (ARANHA, 1989, p.121; MORAES, 2006, p.24).

Ao longo de sua permanência no Brasil, os jesuítas fundaram diversas escolas e bibliotecas, constantemente enriquecidas com obras vindas da metrópole, pois os livros eram indispensáveis ao aprendizado dos alunos, que aprendiam desde as primeiras letras até cursos de filosofia, os quais poderiam ser equiparados a verdadeiras universidades. Para dimensionar o trabalho dos jesuítas em torno dos livros, já em fins do século XVI havia sido instalada uma biblioteca em Salvador; a biblioteca do colégio de Santo Alexandre do Pará, em 1760, dispunha de mais de 2.000 volumes e a do colégio da Vigia, 1.010 volumes. Em meados do século XVIII, o colégio do Rio de Janeiro tinha 5.434 volumes e diversas outras casas jesuíticas tinham seu milhar de livros (MORAES, 2006, p.7). De modo geral, tais bibliotecas não eram restritas aos alunos, mas poderiam ser utilizadas por qualquer pessoa que solicitasse.

Todavia, este cenário modifica-se drasticamente com a reforma pombalina que culmina, em 1759, na expulsão dos jesuítas, movida pelo receio da Coroa em relação à forte influência social e política por eles exercida, e não apenas educacional e religiosa, haja vista o aumento de sua autoridade sobre índios e colonos (ARANHA, 1989, p. 123).

Assim, a educação empreendida pelos padres da Companhia de Jesus teve fim e, de imediato, nada se propôs em seu lugar. É somente após uma década de tal desmantelamento que o Marquês de Pombal inicia a reconstrução do ensino, deixando evidente que o receio em torno do poder transformador da educação sobrepôs-se ao receio do atraso que a extinção do ensino representaria para os que viviam na Colônia (ARANHA, 1989, p.164). 
Tal golpe também atingiu as bibliotecas, que entraram em decadência. Livros foram retirados dos colégios e amontoados em lugares inadequados durantes anos, sendo que a quase totalidade dos acervos foi dilapidada, roubada ou mesmo vendida como papel para embrulho (MORAES, 2006, p.10).

O período de mais de dois séculos deixou resquícios, sendo o mais evidente a tradição religiosa de ensino, que perdurou até o século XIX e ecoou em outros momentos da história da educação brasileira. Sob a determinação de Portugal, os jesuítas educaram índios e colonos, todavia, o receio do aumento da influência dos padres fez romper os laços até então estabelecidos, deixando evidente que tanto a educação como os livros tinham a clara função de impor ordem simbólica condizente aos ideais da metrópole. O ensino foi temido pela Coroa, tendo seu fim decretado e, com isso, educação e biblioteca ficaram longe de serem consideradas um direito dos que aqui viviam.

Após diversas medidas desconexas, é somente a partir de 1772 que providências começam a se dar no campo da educação, com a implantação do ensino público oficial, sob o encargo da Coroa. Entretanto, até o século XIX o Brasil ainda não contava com uma política de educação sistemática. Mudanças eram empreendidas para resolver problemas pontuais e imediatos, deixando-se de lado a importância de tratar a educação como um todo, planejada de acordo com as diversas fases da vida do ser humano (ARANHA, 1989, p.190).

O cenário letárgico começa a se modificar com a vinda da Corte portuguesa para o Brasil, em 1808. Na frota, vieram os tesouros do Estado, arquivos das repartições públicas, a Biblioteca Real bem como uma tipografia completa, novidade em nossas terras. Era o começo de profundas transformações na colônia que, marcada por um atraso lamentável e sem a mínima infraestrutura, passou a ser alvo de diversas ações para melhorar as condições de vida nesta que passaria a ser a capital do Império português.

À época, a situação da instrução pública é, no mínimo deplorável, pois conforme argumentam Lajolo e Zilberman (2003, p.133)

No mesmo ano em que chega a Família Real portuguesa, Delso Renault documenta anúncios, na recém-fundada Gazeta do Rio de Janeiro, de aulas particulares, sobretudo de latim e português, o que, para ele, mostra o "desmantelamento do plano de educação, como um reflexo da expulsão dos jesuítas, em 1759". O mesmo pesquisador encontra indícios de que, em 1819, “o ensino esparso e sem direção prossegue ministrado no mesmo sistema de aulas régias e avulsas". 
Com D. João VI, a condição miserável que marca a educação é alvo de ações e, com isto, também ocorrem mudanças em torno dos livros e bibliotecas. Houve iniciativas de relevo no campo da cultura e da educação, como a fundação dos cursos médico-cirúrgicos no Rio de Janeiro (1809) e Bahia (1812); cursos de agricultura, também na Bahia (1812) e Rio de Janeiro (1814); organização de um gabinete de Química na Corte (1812); instituiu-se a Imprensa Régia (1808); foi inaugurada a Biblioteca Real (1811) e o Museu Real (1808) (ASSIS, 2010, p.51).

Os livros não estavam presentes somente na Biblioteca Real, também constavam dos diversos institutos que abrigavam os referidos cursos superiores criados pelo governo e que necessitavam da formação de bibliotecas. A importância de bibliotecas nas instituições de ensino está presente na Carta lei de 4 de dezembro de 1810 que, ao criar a Real Academia Militar, estabeleceu que "logo que possa formar-se uma biblioteca científica e militar para esta academia, haverá um lente de história militar, que servirá de bibliotecário [...]” (MORAES, 2006, p.95). Com isso, vemos despontar nas determinações oficiais a relevância da biblioteca no processo de ensino-aprendizagem.

Todavia, apesar dos avanços, é preciso observar que os benefícios foram para uma pequena parcela da população e ainda não se evidenciam projeções em torno da educação, a qual só posteriormente será obrigatória ${ }^{6}$. Não havia, por exemplo, estabelecimentos comuns para a educação de crianças. As instituições de ensino destinavam-se, sobretudo, aos membros da elite, enquanto a grande parcela da população era relegada das escolas, nem mesmo sabendo ler e escrever. Por essas vias, tem-se que as bibliotecas alinhavam-se a esta condição excludente, pois eram acessíveis somente aos que podiam transpor a barreira imposta pela decodificação da escrita.

\footnotetext{
${ }^{6}$ É somente na Constituição de 1988 que se consagra o princípio da educação como direito público subjetivo. Assim, é neste momento que a educação inscreve-se nos dispositivos legais como dever do Estado, sendo possível a utilização de instrumentos jurídicos adequados para sua garantia. Importante frisar que a Constituição de 1934 pontuava a gratuidade e obrigatoriedade do ensino, todavia, tal obrigatoriedade referia-se à frequência. Nesse sentido, o conceito de obrigatoriedade escolar "não implicava dever do Estado perante o indivíduo, mas somente dever do indivíduo perante o Estado". Assim, embora o governo oferecesse educação, não havia a previsão de responsabilização criminal das autoridades competentes pelo não oferecimento (HORTA, 1998, p.18-19).
} 


\subsubsection{Brasil Independente: Um Reino Sem Escolas e Bibliotecas}

Com a Independência, em 1822, a precariedade da situação parece transferir-se da colônia à jovem nação administrada por D. Pedro I. Embora a Constituição de 1824 incluísse dois dispositivos acerca da educação - o princípio da gratuidade da instrução primária a todos os cidadãos, bem como a referência ao ensino das ciências, belas letras e artes em colégios e universidades -, muito pouco se fez.

Não demorou para que a disposição legal fosse alterada e, em 1834, por meio de Ato adicional à Constituinte, a reforma do ensino define-se pela descentralização. Assim, a instrução primária e secundária ficou sob responsabilidade das províncias (futuros estados), sendo dever da União somente o ensino superior e a educação no Rio de Janeiro, à época capital do Império. Conforme Lajolo e Zilberman (2003, p.136) argumentam "a ideia não podia ter sido pior", pois marcadas por orçamentos ínfimos e distanciadas da Corte, as províncias não encontraram possibilidades para levar a efeito a tarefa que lhes foi imposta no âmbito da educação.

Com isso, a educação das elites - quem de fato ascendia à universidade - ficou a cargo da Coroa enquanto a educação do povo foi precariamente confiada às províncias que, com a falta de recursos, pouco podiam fazer. Além disso, a situação tornou-se ainda mais complexa pela falta de unidade que marcou a educação, já que não havia pontes ou articulações entre o ensino elementar e o secundário. De acordo com Fernando de Azevedo, tais instâncias formavam "dois mundos que se [orientavam], cada um na sua direção". Esta falta de vinculação entre os currículos dos diferentes níveis de ensino e a falta de exigência de se completar um curso, para iniciar outro, acentuaram ainda mais a precariedade do ensino (ARANHA, 1989, p.191).

Em 1837, imbuído pelo sentimento de responsabilidade pela educação da elite no Rio de Janeiro, o governo transformou o antigo Seminário de São Joaquim no Imperial Colégio de D. Pedro II, que viria a transformar-se em referência no país (LAJOLO; ZILBERMAN, 2003, p.137). Por meio do Regulamento $\mathrm{n}^{\mathrm{o}} 8$, de 31 de janeiro de 1838, instituiu-se, ordenou-se e foi normatizada toda a estrutura administrativa e pedagógica do colégio que deveria servir de modelo à nação. Em meio às disposições legais, é notável a presença de artigos acerca da biblioteca escolar, sendo este o primeiro documento normativo de um colégio brasileiro que 
explicita a existência de tal dispositivo, descrevendo suas características. Dentre estas, destacam-se itens acerca da composição do acervo, a ser constituído a partir de seleção feita pelo reitor; formação do catálogo, que deveria ficar sob responsabilidade do reitor, sendo que uma cópia seria enviada ao Ministro do Império; empréstimo de livros aos alunos e funcionários, autorizado mediante anuência do vice-reitor (ASSIS, 2010, p.56).

Diante da intenção do governo de que o Colégio D. Pedro II servisse de modelo ao Brasil, é possível identificar que havia o propósito de que as províncias, ao criarem escolas, desenvolvessem junto a elas bibliotecas. Contudo, os incipientes investimentos no ensino inviabilizavam a criação de escolas com a infraestrutura do Colégio modelo e, com isso, somente os membros da elite tiveram acesso a este colégio dotado de biblioteca, cujo regulamento era inspirado nos estatutos dos liceus franceses.

Neste cenário marcado pelo descaso do poder público, proliferavam pequenas escolas particulares, formadas por imigrantes portugueses. John Luccock assim descreve tais escolas e a pedagogia predominante:

O mobiliário de que dispunham era reduzido e seus processos de ensino imperfeitos;
apesar do quê, os resultados obtidos, valiosos. As crianças ficavam atravancadas em
cubículos reduzidos e abafados, onde todas liam alto ao mesmo tempo, com grande
aborrecimento cada qual. Mas, embora as escolas se tornassem mais numerosas,
permaneceram elas quase inteiramente em mãos de portugueses e, embora os
mestres comparativamente se multiplicassem em número, uma grande parte do
tempo dos que dispunham, consumiam-no cantando ave-marias (apud LAJOLO,
ZILBERMAN, 2003, p.141).

A expansão destas escolas particulares encontra abrigo na inação do governo que, por meio de decreto de 30 de junho de 1821, permitia "a qualquer cidadão o ensino e a abertura de escolas de primeiras letras independentemente de exame de licença” (LAJOLO, ZILBERMAN, 2003, p.141), deixando evidente que os investimentos nos primeiros anos da educação não eram prioridade do poder público, que transferiu tal atividade a qualquer um que por ela se interessasse, independente de comprovada qualificação.

O quadro esboçado por Luccock permite imaginar a precariedade destes estabelecimentos bem como apontar a carência de livros e a ausência de bibliotecas, também acentuada pela escassez da matéria impressa. Neste sentido, o relato de Kidder (apud LAJOLO; ZILBERMAN, 2003, p.151) é bastante significativo ao sinalizar que em determinadas regiões do interior as crianças aprendiam a ler em manuscritos. Conforme indica, "a matéria impressa é muito escassa, e, no geral, despida de interesse. Quando um 
livro ou jornal vai ter à escola, torna-se propriedade comum e vai passando de mão em mão como se fora algo de que todos pudessem tirar algum benefício".

Além disso, se por um lado havia o Colégio D. Pedro II, fruto de investimento do poder público e marcado por completa infraestrutura que incluía biblioteca, e por outro, proliferassem escolas particulares, precárias e trôpegas na missão de ensinar, é certo que ambas as propostas eram restritas a determinadas parcelas da população, sendo que a grande maioria das crianças e jovens foi deixada à margem do processo educativo.

Com o passar dos anos a inação do poder público em torno do ensino primário e secundário permanece, sendo notável no período de 1860 a 1890 a fundação de importantes colégios particulares, sobretudo católicos e também alguns protestantes. Isto evidencia que no Brasil a educação seguia por vias opostas ao resto do mundo já que, enquanto em outros países a educação cada vez mais se laicizava, entre nós, a ideologia católica voltava a ganhar força no sistema de ensino (ARANHA, 1989, p. 192).

A educação praticada ao longo do Império permite considerar que a ação do poder público foi excludente e elitista. Ao responsabilizar-se apenas pelo ensino superior e pela educação dos jovens ricos que frequentavam o Colégio D. Pedro II, o governo deixa evidente que a educação não era um direito para todos, mas apenas bem simbólico a ser usufruído por aqueles que pertenciam à classe socioeconômica elevada. Durante este período, marcado pelo péssimo estado do ensino, a ausência de livros e bibliotecas prevaleceu. Se existiam, eram poucas e restritas à pequena parcela da população, não compondo a miserável cena que era o ensino primário e secundário.

\subsubsection{Brasil República: Escola Nova e Bibliotecas}

Com o início da Primeira República, em 1889, e a Constituição de 1891, que instaura o governo presidencialista, representativo e federalista, a fisionomia política do país se altera. As ideias republicanas reacendem esperanças e a sociedade começa a conviver com novas concepções sobre vida e cidadania.

A educação também se transforma neste contexto, pautado por ideais de laicização e gratuidade do ensino público, liberdade de ensino e ampliação do ensino primário. A 
passagem do modelo escravocrata para uma sociedade de trabalho livre colabora para que tais mudanças ocorram, já que parcelas da sociedade começam a encarar a educação como um meio de ascensão social (ALONSO, 2007, p.37).

No entanto, tais transformações são lentas e atingem, sobretudo, as regiões mais abastadas do país. Paiva (apud GOMES, 1983, p.33) expõe números assustadores da educação brasileira, explicitando que em 1889, para uma população de aproximadamente 14 milhões de habitantes, a frequência às escolas primárias era de apenas 250.000 alunos. Em 1909, as escolas elementares atendiam a $2,96 \%$ da população brasileira e a menos de $15 \%$ da população em idade escolar.

Neste cenário, em que o sistema de ensino ainda não estava organizado, tem destaque no Estado de São Paulo a Lei $n^{0} 169$, de 7 de setembro de 1893, que instituía os chamados grupos escolares, que vieram a ser uma referência para a educação no país. Tais grupos escolares consistiam em modelo de dispositivo que reuniria num único edifício todas as escolas menores de cada bairro, sendo que os alunos seriam distribuídos em classes seriadas, com padronização do ensino bem como novos métodos de ensino-aprendizagem. Além das novas propostas referentes à sala de aula, os grupos escolares também contariam com ginásio esportivo, sala para professores e bibliotecas. Instaurava-se, assim, uma nova cultura escolar (MARCÍLIO, 2005).

De modo geral, o desenvolvimento de bibliotecas escolares se deu atrelado ao movimento de expansão do ensino. Para Gomes (1983, p.65), a implantação do currículo enciclopédico pode ter motivado a criação de bibliotecas escolares, tendo em vista atender às novas disciplinas. Todavia, devemos atentar que não houve, de fato, uma política federal de educação na Primeira República, muito menos uma política para bibliotecas. As ações empreendidas foram localizadas e não chegaram a alterar em definitivo a situação do ensino.

Nessas circunstâncias, o desenvolvimento de bibliotecas se deu graças à ação de sujeitos específicos como diretores de escolas, certos governantes imbuídos de boa vontade e professores, estes, muitas vezes, cumprindo a função de bibliotecários. Portanto, no universo das escolas públicas brasileiras do início da Primeira República, o desenvolvimento de bibliotecas não se constituiu, de fato, como mérito do poder público, mas sim resultado de ações isoladas empreendidas por idealistas que desejavam a presença de bibliotecas no insípido cenário educacional e editorial. Não foram desenvolvidas políticas em torno da 
biblioteca escolar e esta não se consolidou como bem simbólico a integrar o rol de questões a serem tratadas pelo poder público.

Os sistemas escolares organizados pelos Estados, sob a inspiração das elites, constituíram-se, menos em instrumentos de renovação, voltando-se, sobretudo, à conservação e difusão do ensino tradicional e da cultura dominante. É somente após 1920 - com as transformações advindas com o fim da Primeira Grande Guerra e seus reflexos econômicos, sociais e políticos -, que se inicia um movimento mais consistente contra o analfabetismo, com novas orientações no âmbito da educação. Esta passou, então, a ser encarada como elemento relevante pelo campo político, considerada capaz de transformar o país (GOMES, 1983, p.33; SCHWARTZMAN; BOMENY; COSTA, 1984, p.51).

Dentre as novas propostas, tem destaque o movimento da Escola Nova, encabeçado por nomes como Lourenço Filho, Anísio Teixeira e Fernando de Azevedo. Ao propor a educação pública, gratuita, universal e leiga, o movimento aponta ser dever do Estado tal empreendimento social, já que defendia a educação como caminho para a democratização e transformação da sociedade. Estes intelectuais lideraram um movimento transformador no campo da educação, possível graças a cargos de destaque que ocuparam na estrutura administrativa do ensino ${ }^{7}$.

Por sua vez, ocorreram investimentos governamentais em torno da organização de sistemas estaduais de ensino, fundamentais ao desenvolvimento do país, que começou a ter seu perfil agrário-exportador modificado pelo processo de industrialização.

Nesse contexto, a cena nacional dominada pelo analfabetismo precisava ser alterada; florescia, assim, uma nova orientação no campo educacional. Em defesa da formação de cidadãos críticos e participativos, a Escola Nova contrapunha-se às concepções transmissivistas do ensino e colocava a experiência do aluno como elemento importante do processo de ensino-aprendizagem.

Com isso, a biblioteca escolar encontraria abrigo em uma nova concepção de ensino, que permitiria seu desenvolvimento não mais como mero espaço de guarda de livros. Foram,

\footnotetext{
${ }^{7}$ Fernando de Azevedo assumiu a direção da Instrução Pública do Rio de Janeiro em 1927; Lourenço Filho foi responsável, na década de 1920, pela reforma do ensino público no Ceará e, também, diretor geral do Ensino Público em São Paulo; Anísio Teixeira foi diretor-geral de instrução do governo da Bahia, entre 1924 e 1928, tendo promovido a reforma do ensino naquele Estado e, em 1931, trabalhou junto ao recém-criado Ministério da Educação e Saúde (Fonte: Centro de Pesquisa e Documentação de História Contemporânea do Brasil - CPDOC FGV - <http://cpdoc.fgv.br>. Acesso em: 10 dez. 2013).
} 
assim, empreendidas ações em busca da ressignificação de seu papel, graças às reformas ocorridas no campo da educação.

As transformações vieram acompanhadas de medidas oficiais. No Rio de Janeiro a reforma do ensino, instituída por meio do Decreto $n^{0} 3.281$, e aprovada em 23 de janeiro de 1928, previa a instalação de bibliotecas para alunos e professores em cada escola primária. Já no Estado de São Paulo, com o Código de educação de 1933, que orientava a reforma do ensino paulista, as bibliotecas escolares foram oficialmente instituídas como organismos a comporem a cena escolar (VIDAL, 2004, p. 191).

A reordenação das práticas escolares, com os alunos colocados no centro do processo educativo, trouxe intensa preocupação dos educadores com a biblioteca escolar. De acordo com Vidal (2004, p.206), a leitura passou a ser considerada uma experiência e, ao invés da repetição de conteúdos, o livro transformava-se "em pretexto de recriação. Multiplicado, em oposição ao livro único, deveria proporcionar prazer tanto na leitura individual silenciosa quanto na coletiva, oral, de obras didáticas e de literatura infantil”. A posição de destaque que a leitura assumiu no ensino propiciou a distinção da biblioteca no universo escolar; o provimento de ambientes acolhedores para a leitura, a aquisição de móveis adequados, o empréstimo de livros bem como a criação de horário específico para que os alunos frequentassem a biblioteca, são fatores que evidenciam a nova postura.

Neste período, tem destaque em São Paulo a criação da Biblioteca Infantil Caetano de Campos, em 1925, primeira do gênero em todo o país e que se alinhava à nova concepção de biblioteca. Enquanto isso, no Rio de Janeiro teve relevo, em 1932, a criação da biblioteca da Escola primária do Instituto de Educação, com um acervo inicial de 282 livros, ampliado para 482 volumes, em 1933 (VIDAL,2004, p.196).

As mudanças desenvolvidas em torno da biblioteca escolar foram marcantes e encontraram espaço nas próprias necessidades de leitura que se delineavam no contexto nacional, em que decifrar o código da escrita passou a ser preciso para que as pessoas pudessem lidar com a profusão de materiais impressos, que demarcavam os usos nos universos urbano, social e do trabalho. Logo, foi fundamental o papel da escola para constituir leitores numa cultura urbana em que os signos escritos se multiplicavam; o mundo do trabalho cada vez mais se relacionava a informes e manuais; a cultura social era crescentemente marcada pela profusão de informações jornalísticas (VIDAL, 2002, p.353). 
Apesar dos esforços, as ações e disposições legais não foram suficientes para que a biblioteca fosse definitivamente encarada como dispositivo obrigatório no universo escolar e acabaram lançadas ao esquecimento. As reformas empreendidas pelo escolanovismo tiveram seus rumos alterados com mudanças no cenário político e a biblioteca escolar, que havia começado a se desenvolver sob nova concepção, teve seu fim decretado. $O$ tempo que precisaria para amadurecer e ser considerada indispensável pela sociedade foi insuficiente. Lembremos que neste período o próprio ensino gratuito apenas começava a ser tido como direito de todos e dever do Estado e, por essas vias, a biblioteca escolar ainda era encarada, de modo geral, como elemento acessório. Assim, foi facilmente trocada pela proposta transmissivista, que então se sobrepôs como tônica do ensino brasileiro, minimizando a importância da relação ativa do aluno com o conhecimento.

\subsubsection{A República Nova: Uma Política para a Educação e para os Livros}

A revolução de 1930 trouxe profundas mudanças para o país. Com Getúlio Vargas na presidência, os componentes ideológicos passam a ter presença cada vez mais marcante na vida política e, nesse sentido, a educação foi palco de investimentos, haja vista seu potencial como formadora de mentalidades (SCHWARTZMAN, BOMENY, COSTA, 1984, p.51).

Num movimento que evidencia tanto a responsabilidade como o controle do Estado por determinados setores, ocorreu a criação, por meio do Decreto $\mathrm{n}^{\mathrm{o}} 19.402$, de 14 de novembro de 1930, do Ministério dos Negócios da Educação e Saúde Pública (MES), responsável por todos os assuntos referentes à educação e por planejar reformas na esfera nacional. Por essas vias, a partir deste momento os ensinos primário e secundário passaram por intenso processo de expansão. Entre 1936 e 1951, o número de escolas primárias duplicou, enquanto a quantidade de escolas secundárias quadruplicou, sobretudo, nas regiões urbanas dos Estados mais desenvolvidos. Também aumentou consideravelmente o número de escolas técnicas e, se em 1933 havia 133 escolas de ensino técnico industrial, já em 1945 temse 1.368 escolas e cerca de 65 mil alunos (ARANHA, 1989, p. 244).

A importância conferida pelo governo à educação está representada na fala, de 1935, do então secretário de Educação e Cultura do Distrito Federal, Francisco Campos, que afirmou "no campo da educação é que as ideias trabalham pelo poder. A política de hoje é a 
política de educação. Nela, no seu campo de luta, é que se decidirão os destinos humanos" (1935 apud SCHWARTZMAN, BOMENY, COSTA, 1984, p. 177). Com isso, desvela-se a relevância que a educação assumia aos olhos do governo, sendo a década de 1930 o primeiro momento em que a União passa a investir no ensino primário e secundário.

Com o advento do Estado Novo, em 1937, o governo federal exacerba a intervenção e regulação da vida na sociedade brasileira. Tendo em vista promover uma modernização, em moldes conservadores, são criadas diversas instituições para fomentar e conduzir a produção cultural; o livro, então, torna-se alvo de ações do governo e, por meio do Decreto-lei n ${ }^{\circ} 93$ de 21 de dezembro de 1937, foi criado o Instituto Nacional do Livro (INL). Inicialmente subordinado ao MES, o INL teve atuação na esfera nacional, apresentando como principal função o incentivo à produção editorial, controlando o processo de criação e difusão do livro.

Extinto em 1990, o INL surgiu e se firmou em meio a contextos ditatoriais, preocupados com a centralização das atividades na esfera cultural e, conforme Araújo (2002, p.31), o Instituto constituiu "sua lógica discursiva e atuação social, em torno da questão do livro".

A fala do então ministro da educação, Gustavo Capanema, em 1937, ao justificar a criação do INL, evidencia o valor conferido ao livro

O livro é, sem dúvida, a mais poderosa criação do engenho humano. A influência
que ele exerce, sob todos os pontos de vista, não tem contraste [...] É, portanto dever
do Estado proteger o livro, não só promovendo e facilitando a sua produção e
divulgação, mas ainda vigilando no sentido de que ele seja, não o instrumento do
mal, mas sempre o inspirador dos grandes sentimentos e das nobres causas humanas
(1937 apud ARAÚJO, 2002, p. 31).

Nessa perspectiva, ao longo do período de atuação do INL a política empreendida pelo governo federal se deu em torno da criação e difusão do livro sob os moldes da cultura oficial.

Assim, as transformações iniciadas com a Escola Nova foram interrompidas e a biblioteca escolar não encontrou espaço nas disposições oficiais. Foi tida simplesmente como instituição que deveria receber as obras editadas pelo INL e, nesse sentido, encarada como mero acervo. Todavia, um acervo que deveria estar de acordo com a cultura oficial, caso contrário seria eliminado. Foi o caso das bibliotecas escolares e do Instituto de Educação do Rio de Janeiro que, em 1937, sofreram a retirada de 6.000 livros considerados subversivos (ALONSO, 2007, p.44). 
Na década de 1970, a atuação do INL se deu, sobretudo, em torno da edição de obras didáticas distribuídas às escolas e universidades. Além disso, por meio da Lei Federal $\mathrm{n}^{\mathrm{o}}$ 5.692, de 1971, que reformou o ensino de $1^{\circ}$ e $2^{\circ}$ graus, instituiu-se a obrigatoriedade da pesquisa por parte dos alunos. Contudo, tal obrigatoriedade não trouxe consigo a indicação do desenvolvimento de bibliotecas escolares a oferecer condições para que os alunos realizassem as ditas pesquisas. Assim, face às novas demandas, os estudantes buscaram as bibliotecas públicas já que, de forma geral, não encontravam nas instituições de ensino material ou auxílio para realizar tal tarefa.

Nesses termos, ao longo deste período marcado pela atuação do INL - que se deu em meio a Era Vargas, um breve intervalo democrático e a ditadura militar -, o governo federal empreendeu políticas para a educação bem como para o livro, porém não se apresentaram orientações efetivas em torno do desenvolvimento de bibliotecas escolares. Assim, se a ação política ampliou o acesso ao ensino bem como a produção editorial, elemento este que beneficiou sobremaneira grupos de interesses que comandavam a indústria editorial, é fato que não foram planejadas ações, em âmbito geral do país, tendo em vista a problemática da formação de leitores. Parece que a alfabetização e distribuição de livros, por si só, foram encaradas como elementos suficientes para que vínculos fossem estabelecidos entre o aluno e o universo da leitura.

Tais concepções, face às dificuldades impostas pelos contextos ditatoriais, fizeram retardar possibilidades do florescimento de bibliotecas escolares encaradas como espaços de apropriação da informação e desenvolvimento de uma postura crítica do estudante frente ao universo informacional, haja vista que a construção destes organismos somente encontra abrigo em contextos educacionais abertos às diferenças, marcados pelo diálogo e negociações, e não em cenários que busquem conformar mentalidades.

$$
* * *
$$

O breve sobrevoo pela trajetória da biblioteca escolar brasileira permitiu entrever nuances de um passado que se insinua em nosso presente. O resgate de tempos pretéritos mostrou que com a colonização portuguesa de terras brasileiras também chegaram os livros. A palavra impressa aqui aportava com a intenção de instruir colonos e catequizar indígenas, evidenciando, desde o início, o valor da cultura escrita, do livro, bem simbólico imprescindível à ação pedagógica. 
A importância dos livros nas instituições de ensino se confirma quando observamos, em meio às esparsas ações oficiais em torno da educação, a preocupação com a oferta de acervo de recursos informacionais aos alunos e professores. A matéria impressa era desejada na cena escolar, evidenciando que se constituía uma cultura de biblioteca - entendida como acervo - dentro do ambiente de ensino, a qual se aliava aos ideais de difusão do padrão cultural vigente.

De fato, porém, a educação não alcançava a todos, mas apenas a uma pequena parcela da população com melhores condições socioeconômicas e, nesse sentido, livro e leitura não se constituíram como bens simbólicos de reconhecido valor para a sociedade em geral. Como já mencionado, é somente com a Constituição de 1988 que a educação se inscreve na legislação brasileira, efetivamente, como um dever do Estado, evidenciando que entre nós o próprio direito à educação pública é bastante recente.

Diante disto, é forçoso reconhecer que nossa história foi marcada pela carência de vínculos entre a população em geral e o livro. Nesses termos, a biblioteca escolar nem mesmo chegou a ser apresentada às crianças e jovens em geral, já que os próprios laços com a educação formal apenas começaram a se fortalecer em meados do século XX, quando o ensino passa a ser encarado pelo governo como meio para o desenvolvimento da nação e pela população como forma de ascensão social.

Entretanto, no contexto escolar consagrado a uma prática de ensino transmissivista, as ações do poder público em torno do livro e da leitura foram circunscritas à distribuição de recursos informacionais impressos. Deixou-se de lado a importância do planejamento de ações para promover o efetivo contato das crianças e jovens com a cultura escrita, tarefa que ficou a cargo de professores imbuídos de boa vontade, certos da importância da leitura. Em face disso, as poucas bibliotecas escolares constituíram-se sob a concepção de acervo organizado de livros; não foram alvo de medidas oficiais mais amplas, que considerassem a importância de ações para que os alunos se apropriassem do universo cultural disposto nos livros. A apropriação deste universo escrito foi tratada como ato natural, bastando, para tanto, dominar os processos de decodificação da palavra impressa.

A situação precária da biblioteca escolar acentuou-se, ainda, por sua inserção numa escola fundada sobre o princípio de uma desigualdade social a ser minimizada, ocupada com a adaptação de todos aos padrões vigentes e com a manutenção das elites (RANCIÈRE, 2011, p.12). Nessas circunstâncias, a existência de um interesse da população em geral pelo livro e 
pela leitura era algo complexo, já que as produções impressas difundidas tinham em vista a preservação e transmissão dessa cultura de elite que se buscava impor. Em face disso, embora reconhecidamente importante no universo escolar, as bibliotecas não se constituíram como uma cultura em nosso país, haja vista a carência de laços orgânicos entre este dispositivo e a sociedade em geral.

\subsection{BRASIL CONTEMPORÂNEO: BIBLIOTECA ESCOLAR, INFORMAÇÃo E EDUCAÇão}

Precisamos opor-nos à inteligência cega que passou a comandar por quase toda a parte. Precisamos reaprender a pensar: tarefa de salvação que começa por si mesma.

Edgar Morin

A educação deve ter em vista a transformação do que sabemos e não exclusivamente a transmissão do já sabido. Com isso, sua dimensão libertadora é explorada, permitindo que nos desprendamos de ideias instituídas, apresentadas como naturais e inabaláveis. Assim, não é para formar seres submissos, mas sujeitos que problematizem o mundo, sintam-se por ele responsabilizados, comprometendo-se a transformá-lo, recriá-lo constantemente. Nesta perspectiva, a educação é indispensável à participação dos sujeitos nos espaços políticos e sociais (CURY, 2002; p. 246; GADOTTI, 2012, p. 117; LARROSA, KOHAN, 2011).

A atual Constituição brasileira, promulgada em 1988, inscreve a educação básica - préescola, ensino fundamental e ensino médio - como um direito social, portanto pública e obrigatória, sendo dever do Estado garantir que todos os brasileiros gozem deste direito. Declarar e garantir um direito é bastante significativo, pois equivale a afirmá-lo como alvo de política pública, devendo ser assegurado e implementado. A declaração do direito à educação torna-se fundamental em nosso país - historicamente marcado por desigualdades neste âmbito -, na medida em que retira do esquecimento e proclama aos que não sabem, ou se esqueceram, que eles são portadores de um direito essencial, que deve ser respeitado (CURY, 2002, p. 259).

Nosso sistema educacional tem sua estrutura e funcionamento regulamentados pela Lei de Diretrizes e Bases da Educação Nacional (LDB) - Lei nº 9.394 de 1996. De acordo com o texto legislativo, o dever do Estado se efetiva por meio da garantia da educação básica 
obrigatória e gratuita dos 4 aos 17 anos de idade; educação infantil, às crianças de até 5 anos de idade; bem como da garantia de acesso aos ensinos fundamental e médio para aqueles que não os concluíram na idade adequada.

Por sua vez, cabe pontuar que os Estados devem oferecer prioritariamente o ensino médio e assegurar o ensino fundamental; este último responsabilidade primeira do município, que também é responsável pela educação infantil. À União, cabe elaborar o Plano Nacional de Educação, prestar assistência técnica e financeira aos Estados e municípios e, em conjunto com estes, estabelecer diretrizes norteadoras dos currículos escolares (BRASIL, 1996).

O direito de acesso à educação vem sendo crescentemente efetivado em nosso país. Os números do Censo escolar de 2012 evidenciam isto ao apontarem para um cenário composto por 192.676 estabelecimentos de educação básica, dentre a rede pública e a privada, com 50.545.050 alunos matriculados, sendo 42.222 .831 (83,5\%) em escolas públicas e 8.322.219 $(16,5 \%)$ em escolas da rede privada (INEP, 2013).

Todavia, é preciso problematizar a educação praticada nas escolas brasileiras, pois se é certo que "cada geração dá nova forma às aspirações que modelam a educação em seu tempo" (BRUNER, 1968, p.1), também o é que em nosso país a pirâmide educacional acompanhou muito de perto a pirâmide de distribuição de renda e riqueza, ficando os mais pobres à margem da educação. A escola consagrou uma prática transmissivista de ensino, que aspirava à assimilação das pessoas aos padrões vigentes. Assim, reinou neste circuito uma tradição difusionista, oposta a processos críticos e criativos que visam à formação de sujeitos.

Portanto, em nossas escolas a experiência - que dá sentido à educação - foi deixada do lado de fora, sendo autorizada somente a entrada da verdade nas salas de aula. Nessas circunstâncias, tal como indica Chauí (1989, p. 4), é fundamental compreender o saber como um trabalho para "elevar à dimensão do conceito uma situação de não-saber". Ou seja, o saber requer a transformação da experiência imediata, o trabalho para tornar as indeterminações inteligíveis. Portanto, implica reflexão que aceite o risco das incertezas, que parta de uma interrogação admitindo, de antemão, que não há garantias prévias.

Em face disso, é essencial que a abordagem pedagógica na forma de tratamento dos conteúdos escolares seja ressignificada em nosso país. Mais que isso, precisamos interrogar as bases da educação brasileira, determinando se têm por princípio uma desigualdade a ser minimizada ou uma igualdade a ser verificada. Ou seja, é necessário compreender se nosso 
sistema de ensino assume a desigualdade como algo natural aos indivíduos e, com isso, propõe-se a minimizar esta desigualdade reconhecendo, entretanto, que apenas alguns serão mestres, enquanto uma grande maioria terá como limite o conhecimento das matérias do programa curricular. A desigualdade como premissa do ensino posterga ao infinito as desigualdades sociais e, para Rancière (2011, p.11-12), é preciso que "a igualdade jamais [venha] após, como resultado a ser atingido. Ela deve sempre ser colocada antes", como pressuposto, forçando uma capacidade que se ignora ou se recusa a reconhecer, desenvolvendo, com isso, todas as consequências deste reconhecimento.

Trata-se, portanto, de uma questão política que implica reconhecer as bases de nosso sistema de ensino e, nesse sentido, demanda ações para que as escolas constituam-se, de fato, como espaços democráticos. E para tanto, é preciso políticas de educação efetivamente democráticas que sejam, ao mesmo tempo, sociais e pedagógicas (LIMA, 2008, p.141).

Nesta urdidura, no tocante à biblioteca escolar, predominam iniciativas oficiais circunscritas à distribuição de livros; é o caso do Programa Nacional do Livro Didático (PNLD) e do Programa Nacional Biblioteca da Escola (PNBE) que, conforme o Ministério da Educação (MEC), relacionam-se ao livro, à leitura e à biblioteca (MEC, 2011, p.5).

O PNLD surge em 1985, por meio do decreto $\mathrm{n}^{\circ}$ 91.542, e tem como objetivo principal "subsidiar o trabalho pedagógico dos professores por meio da distribuição de coleções de livros didáticos aos alunos da educação básica" (MEC, 2013).

Já o PNBE, criado em 1997, tem por objetivo "democratizar o acesso de alunos e professores à cultura, à informação e aos conhecimentos socialmente produzidos ao longo da história da humanidade, pela distribuição, às escolas, de acervos, obras de referência e de literatura infantil, juvenil e adulta” (MEC, 2011, p.10). O programa oficial confunde a distribuição de livros com o desenvolvimento de bibliotecas, o que se evidencia no nome conferido à política pública "Programa Nacional Biblioteca da Escola", ou seja, a questão do acesso ao livro é igualada à questão biblioteca escolar ${ }^{8}$.

\footnotetext{
${ }^{8}$ Conforme Paiva e Beremblum (2009, p.182), ao apresentarem e discutirem resultados de pesquisa sobre o PNBE, a simples ação de oferta de livros às escolas é insuficiente, pois "como se pôde constatar, o trabalho escolar baseia-se principalmente em livros didáticos, e é pouco frequente o desenvolvimento de atividades com outros tipos de texto. A simples distribuição de livros nas escolas não mudará, portanto, as práticas pedagógicas em relação ao uso de livros de literatura nem a apropriação e construção de novos sentidos a partir da leitura. Nos casos em que esses materiais são utilizados, o trabalho pedagógico continua marcado por uma forte tendência à decomposição de textos para o estudo de gramática prescritiva, em busca de respostas corretas e únicas interpretações para a leitura. A democratização do acesso a obras literárias, esperado a partir da
} 
Por sua vez, pesquisas empreendidas pelo MEC evidenciam números sobre a existência de bibliotecas e salas de leitura nas escolas de educação básica. De acordo com o Censo escolar de 2012, o Brasil conta com 21.989 escolas privadas de ensino fundamental e destas, 84,4\% afirmam possuir biblioteca ou sala de leitura. Já as escolas privadas de ensino médio totalizam 7.885, sendo que 93,4\% afirmam contar com biblioteca ou sala de leitura. Enquanto isso, no sistema público de ensino, das 122.716 escolas de ensino fundamental, 42,2\% dizem ter biblioteca ou sala de leitura; e dentre as 19.279 escolas de ensino médio, $87,4 \%$ afirma possuir biblioteca ou sala de leitura (INEP, 2013).

Todavia, estes números devem ser observados com a mais absoluta cautela, dado que o quadro foi constituído a partir da resposta das escolas às questões do Censo escolar. Assim, o Censo indagou às escolas se elas possuíam biblioteca ou sala de leitura e, para orientar as respostas, explicitou biblioteca escolar como "local que dispõe de coleção de livros, materiais videográficos e documentos registrados em qualquer suporte destinados à consulta, pesquisa, estudo ou leitura". Já as salas de leitura foram definidas como "espaço destinado à consulta, leitura e estudo dos alunos" (INEP, 2012).

Nessa perspectiva, embora a pesquisa evidencie uma diferença entre a biblioteca e a sala de leitura, que se dá na medida em que a primeira dispõe de um acervo destinado aos alunos, enquanto a segunda não apresenta o acervo como elemento característico, os resultados são apresentados sem diferenciação evidenciando uma aparente igualdade entre biblioteca escolar e sala de leitura para o MEC.

Diante deste contexto, expõe-se a problemática implicada na concepção deste dispositivo, haja vista que os programas federais que o MEC afirma serem relacionados ao livro, à leitura e à biblioteca são restritos à distribuição de recursos informacionais impressos às escolas públicas. Embora não haja dúvidas com relação à necessidade de que os alunos tenham o direito de acesso à informação, também é certa a urgência de que tenham o direito de saber informar-se. Ultrapassar tais fronteiras é fundamental à nossa sociedade, pois conforme alerta Gadotti (2012, p.163), "não existe uma sociedade moderna e democrática sem um sistema educacional moderno e democrático [...] existe uma vinculação estreita entre Educação e Sociedade". E, nesse sentido, não servem quaisquer tipos de bibliotecas, ou mesmo a reprodução dos modelos que marcaram nossa história.

distribuição de livros [...] parece não ter sido alcançada. A disponibilidade de textos literários e de obras de referência na cultura escolar não é suficiente para transformar as práticas pedagógicas privadas e autoritárias. 


\subsubsection{Biblioteca Escolar Brasileira: Do Passado ao Presente, Qual o Futuro?}

A biblioteca escolar foi alvo de proposição oficial no ano 2000, quando a então deputada federal Esther Grossi apresentou o Projeto de Lei $\mathrm{n}^{0} 3.549$, dispondo sobre a universalização de bibliotecas escolares. Todavia, o Projeto de Lei (PL) não chegou a ser encaminhado à Presidência da República, para sanção ou veto, pois a legislatura da deputada proponente terminou antes desta fase. Assim, foi arquivado, conforme regulamenta o artigo 105 do Regimento interno da Câmara dos Deputados, em casos de fim do mandato do proponente.

É no ano de 2003 que o então deputado federal Lobbe Neto apresenta o Projeto de Lei ordinária $^{9} \mathrm{n}^{\mathrm{o}} 1.831$ (ANEXO B) que, segundo a justificação, é uma reapresentação do PL proposto por Esther Grossi. Importante observar que o PL n ${ }^{0} 1.831 / 2003$ constituiu-se a partir da intenção do deputado em resgatar as disposições do PL n ${ }^{0} 3.549 / 2000$, todavia, não há vínculos entre ambos em termos de tramitação das proposições no Legislativo.

O PL n ${ }^{0} 1.831 / 2003$ sofreu algumas modificações ao longo de seu percurso, dentre as quais: a alteração da quantidade mínima de livros indicados para compor o acervo das bibliotecas, de 4 livros por aluno matriculado para 1 título; o aumento do prazo para o cumprimento da lei, de 5 para 10 anos; a inclusão de item determinando o respeito à profissão do bibliotecário. A referida proposição tramitou ao longo de sete anos e, com as modificações sugeridas, foi aprovada em abril de 2010, por meio da decisão favorável da Comissão de Educação, Cultura e Esporte do Senado Federal, conforme indicado no Parecer do relator, o senador Cristovam Buarque. Assim, o Projeto de Lei terminou de tramitar no Legislativo e foi encaminhado à Presidência da República, tendo sido sancionado e publicado como Lei Federal $n^{\circ} 12.244$, em 24 de maio de 2010.

Com isso, o país passou a dispor de uma determinação oficial para assegurar a criação de bibliotecas escolares, fazendo com que deixem de se configurar, sobretudo, como substantivo abstrato em nossa realidade, marcada pela carência (quantitativa e qualitativa) destes dispositivos. Carência esta que se comprova pela própria necessidade da referida lei

\footnotetext{
${ }^{9}$ Projetos de leis ordinárias referem-se aos projetos de leis comuns, não previstas na Constituição e sem a intenção de alterá-la. (Fonte: < http://www.plc122.com.br/projeto-de-lei/>. Acesso em: 03 mar. 2014).
} 
que, para Nêmora A. Rodrigues ${ }^{10}$, é a "lei do óbvio", necessária para assegurar que as escolas tenham condição fundamental para existir, uma biblioteca. Todavia, embora obviedade para alguns, certamente a biblioteca escolar é dispensável para muitos.

Neste contexto, é certa a existência de forças que atuaram em busca de criar possibilidades para o surgimento da lei e, conforme Nêmora A. Rodrigues expõe, o CFB trabalhou

[...] para construir o cenário para a aprovação da lei, o que foi comprovado pelo secretário da Comissão de Educação do Senado, ao nos afirmar que a velocidade com que o PL saiu da Câmara e chegou ao Senado era impressionante e que o mérito era todo nosso.

O esforço empreendido pela categoria profissional bibliotecária em torno da questão se pronuncia há tempos, pois conforme José Fernando Modesto da Silva ${ }^{11}$, no começo da década de 1990, tiveram início diversas ações do CRB8 para explicitar a importância das bibliotecas escolares. Tais ações se deram por meio da apresentação de propostas para o governo do Estado de São Paulo, tendo em vista fazer com que as bibliotecas se tornassem, de fato, realidade nas escolas paulistas ${ }^{12}$. A busca de diálogo com o campo político foi constante e, de acordo com Modesto, o texto do PL $n^{0} 3.549 / 2000$ foi fruto de articulação de membros do Conselho com a então deputada federal Esther Grossi. Tendo elaborado um PL para bibliotecas escolares, a deputada apresentou-o aos membros do CRB8, que se incumbiram de rever e alterar o texto, caso julgassem necessário, para então devolvê-lo para que Esther Grossi analisasse as alterações, eventualmente sugeridas, e encaminhasse a proposição à Câmara dos Deputados.

As ações empreendidas pelo CRB8 se solidificaram e este Conselho então encaminhou ao CFB os projetos desenvolvidos. Tal articulação levou o CFB a lançar o Projeto mobilizador: biblioteca escolar, construção de uma rede de informação para o ensino público $^{13}$ que, conforme Nêmora A. Rodrigues afirma, surgiu a partir "da reflexão de que o

\footnotetext{
${ }^{10}$ Nêmora Arlindo Rodrigues, ex-presidente do CFB, respondeu em 25 de abril de 2013 às questões enviadas via-email. As questões podem ser consultadas no Apêndice A.

${ }^{11}$ José Fernando Modesto da Silva, professor universitário que já ocupou a presidência do CRB8 e do CFB, nos concedeu uma entrevista em 12 de dezembro de 2013. As questões podem ser consultadas no Apêndice A.

${ }^{12}$ A documentação que consta no arquivo do CRB8 comprova as ações empreendidas. Além da própria documentação interna, trocada entre os membros do Conselho, é possível destacar a presença de documentos enviados à Secretaria de Estado da Educação de São Paulo, com o intuito de articular possibilidades para a criação de bibliotecas escolares.

${ }_{13}$ Disponível em: <http://www.cfb.org.br/UserFiles/File/promobil/PROMOBILFINAL.pdf >. Acesso em: 04 mar. 2014.
} 
Sistema CFB/CRB deveria adotar uma causa social e assim demonstrar a sua importância”, sendo que optaram pela biblioteca escolar por ser "a base de todas as demais bibliotecas, fundamental na vida do cidadão e, infelizmente, a menos valorizada, muitas vezes inexistente e a mais carente".

O CFB desenvolveu ações com o intuito de sensibilizar a classe política acerca da importância das bibliotecas escolares e, assim, demonstrar a relevância da aprovação do PL $\mathrm{n}^{\circ}$ 1.831/2003. De acordo com Regina Celi Sousa ${ }^{14}$, dentre as ações, o CFB realizou uma campanha e montou

[...] dentro da Câmara dos Deputados uma biblioteca escolar com mobiliário, acervo, computadores com acesso às bases de dados, espaço de pesquisa, teatro, além disso, fez uma exposição, tratando da biblioteca escolar nos corredores da Câmara, com o objetivo de causar impacto nos políticos e demais visitantes da Câmara.

Todavia, as ações da categoria profissional organizada não se deram em conjunto com uma mobilização da sociedade em geral ou de profissionais da educação, pois, conforme argumenta Nêmora A. Rodrigues, "não houve pressão da sociedade. Ao contrário, [o CFB] que [clamou] pela mobilização da sociedade". Regina Celi Sousa tem posicionamento semelhante e afirmou que "a demanda partiu e parte significativamente da comunidade profissional. Manifestações sociais são escassas neste sentido, até por desconhecimento da população".

A Lei $n^{\circ}$ 12.244/10 levou a desdobramentos na esfera legislativa e, em 2012, o deputado federal Sandes Junior apresentou, na Câmara dos Deputados, o PL n ${ }^{\circ} 28$ que propunha alterações na LDB para "instituir a obrigatoriedade de criação e manutenção de bibliotecas escolares em todas as instituições públicas de ensino" (BRASIL, 2012). Com isso, foi desvelada a intenção política de desobrigar a rede particular de ensino de cumprir as disposições legais, numa tentativa de manter a biblioteca escolar na condição de privilégio, ao invés de consolidá-la como direito de todos. Neste caso, propunha-se que o privilégio fosse apenas para aqueles que frequentam o sistema público de ensino. Para Nêmora A. Rodrigues, o PL caracterizou o resultado "da pressão exercida pelas entidades privadas para se desobrigarem de cumprir a lei”, pois isto implicaria um aumento de custos já que, além da biblioteca, demandaria a contratação de profissional bibliotecário.

\footnotetext{
${ }^{14}$ Regina Celi Sousa, atual presidente do CFB, respondeu em 28 de janeiro de 2014 às questões enviadas via email. As questões podem ser consultadas no Apêndice A.
} 
O CFB posicionou-se contrariamente ao $\mathrm{PL} \mathrm{n}^{\mathrm{o}}$ 28/2012 e, ao longo da tramitação na esfera legislativa, este sofreu alterações e constituiu-se com nova redação, que findou com a ameaça de que apenas as escolas públicas deveriam possuir bibliotecas ${ }^{15}$.

Diante desta trajetória, e com convicção da relevância do surgimento de uma lei com vistas a garantir a presença de bibliotecas nas escolas brasileiras, não nos escapam inquietações acerca dos passos a serem dados para que a intenção oficial extrapole as fronteiras do papel e transforme a biblioteca, de fato, em substantivo concreto na cena escolar.

Nesse sentido, é preciso mais que ações pontuais ${ }^{16}$. O percurso da Lei $\mathrm{n}^{0} 12.244 / 10$ mostrou que não houve mobilização da sociedade ou de representantes da educação clamando por bibliotecas escolares, mas, sim, o esforço da corporação bibliotecária em torno da questão. A inexistência de outras categorias nesta empreitada evidenciou a ausência de relações entre a escola e a biblioteca, que precisa ser fruto de um esforço conjunto, indispensável no contexto da educação brasileira.

Ademais, o conceito de biblioteca escolar apresentado na lei também é problematizado. Conforme argumenta José Fernando Modesto da Silva, conceituar biblioteca escolar é um problema no âmbito da própria Biblioteconomia, pois de forma geral

[a área] não tem uma definição pontual, clara [...]. As definições são problemáticas e isso fica manifestado nas leis que transitam [...]. Precisamos conceituar mais claramente e isto é um problema da área, é incrível como a própria área não se volta para seu objeto. Estamos discutindo websemântica, informática etc., mas, efetivamente, o núcleo da área não estamos discutindo, não estamos inserindo [a questão da biblioteca escolar] dentro do contexto contemporâneo, tecnológico, da sociedade da informação.

\footnotetext{
${ }^{15}$ Conforme o site do Senado Federal, o PL n ${ }^{0}$ 28/2012 encontra-se na seguinte situação: “Ao gabinete do relator, Senador Cássio Cunha Lima, para análise da emenda n. 02 - PLEN (SUBSTITUTIVA) de autoria do Senador Paulo Paim, ao substitutivo do PLC n ${ }^{\circ} 28$, de 2012”. Nesta emenda é problematizada a figura do profissional que irá atuar nas bibliotecas escolares. Disponível em: < http://www.senado.gov.br/atividade/materia/detalhes.asp?p_cod_mate=105187 >. Acesso em: 04 mar. 2014.

${ }^{16}$ No momento, a Universidade Federal do Rio de Janeiro (UFRJ) em parceria com o CFB vem desenvolvendo ações para oferecer curso de graduação em Biblioteconomia na modalidade Educação à distância o que, segundo Fernando Modesto da Silva, configura-se como uma tentativa de "acelerar o número de profissionais formados para atender esse segmento". O CFB em parceria com o Grupo de Estudos em Biblioteca Escolar (GEBE) lançou o documento Biblioteca escolar como espaço de produção do conhecimentos: parâmetros para bibliotecas escolares, tendo em vista oferecer subsídios ao desenvolvimento de bibliotecas nas escolas. Além disso, o Instituto Ecofuturo, sediado em São Paulo, lidera uma campanha pela efetivação da lei.
} 
Nesse sentido, a problemática em torno da biblioteca escolar acentua-se na ordem globalizada contemporânea - marcada pelo desenvolvimento tecnológico com a profusão de estímulos visuais, sonoros, textuais, audiovisuais -, em que a informação adquiriu novos contornos que lhe conferiram posição de destaque. Por outro lado, o universo escolar, mesmo que paulatinamente, também passa por transformações; a voz do professor como fonte quase que exclusiva de informações necessárias ao processo de aprendizagem está se despolarizando e é preciso que a Escola esteja apta a lidar com essa nova realidade em termos de acesso, circulação e recepção de informações.

Diante desse panorama - em que ações implicam redefinições da própria educação, bem como um trabalho dos profissionais que irão atuar nas bibliotecas escolares, no sentido de se apropriarem delas, desenvolvendo ações capazes de redefinir posições destes dispositivos no quadro contemporâneo -, a formulação de políticas públicas para orientar a implantação de bibliotecas escolares é urgente e, certamente complexa, pois se depara com múltiplos desafios, uma vez que, além de criá-las, precisa ser capaz de ressignificá-las.

No entanto, se por um lado a tomada de consciência acerca de uma realidade problemática é fundamental, por outro é certo que não basta revelá-la, precisamos dar um passo além, em busca de alternativas para a superação do quadro apresentado; nesta empreitada, lançamo-nos nas próximas páginas deste estudo. 


\section{POLÍTICA: PELA CRIAÇÃO DE POSSIBILIDADES}

[A política] cria ou recusa condições de possibilidades. Interdita ou permite: torna possivel ou impossivel.

De Certeau (1996, p.214).

A premência em propor possíveis rotas para transformações na atual conjuntura da biblioteca escolar brasileira é o mote deste capítulo, cujo objetivo é discutir a política em perspectiva democrática. Além das formas pelas quais a política opera, seus porquês serão alvo de considerações para que se evidencie a relevância da conquista da "liberdade de pensar a liberdade na sociedade", (LEFORT, 1991, p. 24) reflexão fundamental, justamente por compreender aquilo que motiva os homens a conviverem politicamente organizados (ARENDT, 2005, p. 191).

Não sendo a democracia definida por atos participativos ou consensuais, mas sim pelo respeito às liberdades e à diversidade, será ela o fio condutor de nossas elucubrações acerca de políticas públicas, pois longe de ser um fim em si mesma, a democracia é condição indispensável à construção, por parte de diferentes atores, de um mundo que, de fato, pertença a todos (TOURAINE, 1996, p.180).

Assim, nos propomos a refletir sobre o desenvolvimento de políticas públicas para bibliotecas escolares democráticas, o que nos remete ao alerta de Marilena Chaú, para quem talvez a condição social mais urgente da democracia seja a questão da informação, pois

[...] um indivíduo participa da vida social em proporção ao volume e à qualidade das informações que possui, mas, especialmente, em função de sua possibilidade de acesso às fontes de informação, de suas possibilidades de aproveitá-las e, sobretudo, de sua possibilidade de nelas intervir como produtor do saber (CHAUÍ, 1989, p. 146-147, grifo nosso).

\subsection{DEMOCRACIA}

No contexto globalizado, com a transformação cada vez mais marcante do cidadão em consumidor, a democracia evidencia sua fragilidade. A figura do sujeito - no sentido daquele que se constitui na medida em que tem experiências pessoais, conferindo sentido àquilo que é 
e ao que lhe acontece - é cada vez mais rara; a recusa do outro aumenta e, assim, são consumidas as possibilidades de construção de um espaço político democrático, já que, reduzido a um mercado político relativamente aberto, não se constitui como objeto de investimentos intelectuais ou afetivos (LARROSA BONDIA, 2002, p.21; TOURAINE, 1996, p.10).

Entranha-se na sociedade o maior apreço aos objetos em detrimento das relações sociais, assim, os indivíduos acabam por conceberem-se como integrantes de uma sociedade que se define pelo consumo, conferindo maior atenção a atividades menos importantes, dentre as quais se inclui o consumo desnecessário. Basta assistir a um canal de televisão por breves instantes para constatar que se fala muito mais em detergentes, carros, roupas e cereais integrais do que sobre escolas, bibliotecas e hospitais; isto só faz comprimir o já escasso debate político.

Nesses termos, de acordo com Touraine (1996, p. 186), a democracia apresenta-se como um esforço no sentido de "passar do consumo individual de bens materiais para escolhas sociais que coloquem em questão determinadas relações de poder e princípios éticos". Tal transformação abre caminhos para que acima do indivíduo consumidor esteja o sujeito, ou seja, o indivíduo que pretende ser um ator social, com vontade e capacidade para controlar seu meio ambiente, bem como ampliar sua esfera de liberdade e responsabilidade.

Assim, a modesta caracterização da democracia como o conjunto de medidas para evitar que determinados dirigentes tomem ou mantenham-se no poder contra a vontade da maioria não é suficiente, já que ela é condição imprescindível para que diferentes atores construam um mundo que seja efetivamente de todos. Portanto, conforme Charles Taylor, "a democracia é uma política de reconhecimento do outro", implicando a desmassificação da sociedade por meio da multiplicação de espaços e processos de decisão que possibilitem uma aproximação entre preferências pessoais e interesse público, a partir do reconhecimento, por parte de cada um, de seus particularismos, gostos e tabus, bem como da existência do outro, também carregado de desejos e especificidades próprios (1992 apud TOURAINE, 1996, p.112, p.180, 199).

A democracia, nessa perspectiva, coloca-se a serviço dos seres humanos enquanto Sujeitos, ou seja, criadores e produtores de si mesmos e de sua vida individual e coletiva. Ela é o caminho para a efetivação de uma educação que ultrapasse meras preocupações utilitárias, contemplando a relevância de que os seres humanos não sejam somente educados em termos 
de qualificações técnicas, mas também em seus propósitos, de modo a influírem afirmativamente no mundo em que vivem (RUSSELL, 2002, p.42; TOURAINE, 1996, p.34).

Nesse sentido, a democracia não se limita a procedimentos institucionais que garantam a liberdade do debate político. Pois se é certa a importância de se eleger os governantes - por meio da liberdade de associação e expressão, complementada por regras de funcionamento das instituições que visem impedir o desvio da vontade popular e a corrupção -, também é certo que o respeito às regras do jogo em medida alguma impede que as oportunidades de participação sejam extremamente desiguais entre grupos sociais. Desse modo, torna-se imprescindível ir além de definições puramente procedimentais e compreender a democracia em sua substância, como a forma política que dá forma à soberania popular, sendo uma crítica contra poderes estabelecidos e, em si mesma, uma esperança de libertação pessoal e coletiva (TOURAINE, 1996, p.159, 182).

Um sistema político efetivamente democrático deve admitir a existência de diferenças e conflitos de valores insuperáveis já que a recusa do outro é um golpe letal à democracia, necessária porque

[...] o desenvolvimento econômico pressupõe, simultaneamente, concentração dos investimentos e repartição dos produtos do crescimento, e porque não há regra técnica que permita combinar essas duas exigências, certamente, complementares, mas igualmente opostas; somente uma decisão política poderá escolher o peso relativo de cada um desses dois componentes do desenvolvimento econômico; quanto à democracia, é o reconhecimento desse processo político, de sua abertura e transparência (TOURAINE, 1996, p.165).

Diante disto, constata-se que a ideia democrática tem por princípio conflitos e negociações; rejeita discursos que prescrevam a homogeneidade e o consenso, assim como proposições que a limitem a um mercado político aberto povoado por consumidores. Nega, portanto, a redução do indivíduo a ser exclusivamente peça que compõe uma máquina, assim como seu confinamento a definições homogeneizantes de uma dada comunidade, elementos estes que subtraem do ser humano a capacidade de se constituir como um sujeito, protagonista de suas ações no mundo em que vive.

A partir de Touraine (1996, p.175), ressalta-se que a democracia, muito além de garantias institucionais, é uma cultura, e enquanto tal, fundamental para que indivíduos sejam sujeitos, que consigam, por meio de suas práticas e representações, não somente uma integração de sua capacidade de manipular técnicas e linguagens, mas também a integração 
"de sua identidade que se apoia em uma cultura e tradição, reinterpretadas constantemente por eles em função das transformações do meio técnico".

Portanto, a efetivação de um projeto democrático pressupõe desejo e ação coletivos, implica negociações e conflitos, já que a democracia não é uníssona, mas construção conjunta baseada no reconhecimento do valor de uma coletividade que é diversa. Nesses termos, a democracia coloca-se a serviço da formação de sujeitos criadores de si mesmos e do mundo, sendo construída por esses mesmos sujeitos, capazes de atribuir sentido ao que são e a suas experiências.

A democracia carrega em si o desejo de alcançar o impossível, pois é a partir daí que são construídas e reconstruídas rotas conjuntas para transformações em nossas vidas e no mundo. Logo, o impossível precisa ser almejado e situações presentes não podem ser aceitas como naturais e inabaláveis; esta é a ideia democrática, e é a partir dela que propomos uma reflexão acerca de políticas públicas para bibliotecas escolares.

\subsection{Política Pública: Conceitos e Definições}

Desde que situada na ideia democrática de uma sociedade que acolha conflitos de opiniões e o debate sobre direitos, a política apresenta-se como caminho para "auxiliar os homens a tentar o impossível e, com isso, acumular forças para realizar o possível e ir além”. Assim, no contexto brasileiro é possível afirmar que ela implica numa reforma de estruturas que contemple novas articulações entre Estado e sociedade civil, grupos e indivíduos, economia e política (NOGUEIRA, 2004, p. 101; LEFORT, 1991, p. 52).

Portanto, a política deve ser reinventada como projeto e prática que vá além da política dos políticos; precisa pertencer à vida das pessoas, ajudando-as a responder a suas necessidades e anseios. Para Barcellona (1997 apud NOGUEIRA, 2004, p. 101), isto significa restituir o fazer política como atividade ocupada com questões essenciais ao ser humano, não para trazer respostas definitivas, mas para que nunca deixemos de nos perguntar "quem somos, por que estamos juntos e que objetivo desejamos alcançar”.

Destas interrogações advém que, se na perspectiva clássica, política (Politikós) é adjetivo que tem origem em polis, palavra grega referente às coisas da cidade, ou seja, o que 
é urbano, público, social e civil, na perspectiva moderna, em contraponto à noção ligada a polis, política diz respeito, sobretudo, à atividade ou conjunto de atividades que, de algum modo, fazem menção ao Estado, vinculando o conceito de política à ideia de poder. Há que se considerar, todavia, a urgência da compreensão de que toda comunidade é uma ordem política, uma polis, e que a política - não estando na essência do homem, pois não é substância que nasce em cada ser - brota da relação entre os homens, da necessidade de que o futuro seja projetado como experiência a ser vivida coletivamente. Portanto, diz respeito a todos (ARENDT, 1997, p.46; NOGUEIRA, 2004, p.62; RODRIGUES, 2011, p. 13).

Em termos de compreensão lexical, vale destacar que no idioma português o termo política comporta três acepções, cujas correspondências ganham terminologias distintas no idioma inglês. Embora na realidade política tais dimensões estejam entrelaçadas, faz-se necessário conhecer essa distinção conceitual para explicitar o recorte epistemológico em pauta neste estudo.

Primeiramente, temos política concebida como o âmbito do governo, as instituições políticas, referindo-se, assim, à ordem do sistema político bem como à estrutura institucional do sistema político-administrativo: em inglês, polity.

Em uma segunda dimensão, política denomina os processos políticos, frequentemente conflituosos, pois estão relacionados à atividade de organização e luta pelo controle do poder: em inglês, politics.

Por fim, política em sua dimensão material, referindo-se aos conteúdos concretos, aos propósitos e programas políticos empreendidos pelas autoridades públicas: policy em inglês (FREY, 2000, p.216-217).

Inserida nesta dimensão material, a política pública, na década de 1970, foi sintetizada como "aquilo que o governo escolhe ou não fazer" (DYE, 1972 apud HOWLETT; RAMESH; PERL, 2009, p.5, tradução nossa). Apesar da simplicidade para diversos propósitos analíticos, esta definição tem seus méritos; dentre estes, destaca-se a especificação do Estado como agente primário da política pública. Assim, quando falamos de políticas públicas, estamos a discorrer sobre iniciativas sancionadas pelo Estado para regular a sociedade, por meio de ações jurídicas, sociais e administrativas (RODRIGUES, 2011, p.18).

Para Secchi (2011, p. 2), porém, esta é uma abordagem estatista das políticas públicas, em que são consideradas monopólio de atores estatais. De acordo com o autor, tal concepção 
é redutora, uma vez que, nesta perspectiva, não se trata de defini-la pelo seu objeto público, mas, sim, pela personalidade jurídica do protagonista, nesses termos, somente se constituiria como pública ao emanar do Estado. $\mathrm{O}$ autor filia-se à abordagem multicêntrica, que considera “organizações privadas, organizações não governamentais, organismos multilaterais, [...] juntamente com os atores estatais, protagonistas no estabelecimento de políticas públicas”. Assim, quando uma Organização Não-Governamental (ONG) de proteção à natureza lança uma campanha de preservação de rios e mares, está fazendo política pública, pois, está orientando a ação com o intuito de enfrentamento de problema coletivo.

Todavia, ao presente estudo, é inevitável a abordagem estatista de políticas públicas, considerando que estas, além de tratarem de problema público, devem ser elaboradas e implementadas pelo Estado, sem o qual a situação das bibliotecas escolares não será transformada. Assim, não se trata de considerar o Estado como aquele que tem o privilégio exclusivo sobre o fazer político, mas, sim um agente que regula a partir de uma autoridade que foi legitimamente delegada, representando a vontade da maioria nas políticas públicas, que precisam ser elaboradas com a participação dos cidadãos, como caminho para a construção de um mundo comum a todos.

Portanto, neste estudo, o conceito de público, presente no contexto das políticas, não significa simplesmente a ação do Estado frente a um problema que afeta a coletividade, mas também reafirma "a natureza pública das políticas públicas na medida em que permite precisar que o objeto das políticas está nos espaços de relação que se produzem entre a sociedade e o Estado" (MEDELLÍN TORRES, 2004, p. 48). E é este Estado, seja por meio da Administração Direta ou da Administração Indireta (fundações, sociedades de economia mista, autarquias, etc.) ou, ainda, por meio dos demais poderes estatais constituídos Legislativo e Judiciário -, o sujeito ativo principal das políticas públicas (AITH, 2006, p. 233).

De acordo com González-Suárez (2008, p. 147), política pública é conceito que abrange as disposições oficiais emitidas pelo Estado, incluindo a Constituição, tratados, legislação, regulamentações, bem como a definição do modo de agir para alcançar aquilo que foi proposto. Assim, designa "um conjunto formado por objetivos coletivos, considerados necessários ou desejáveis, e por meios e ações tratados, ao menos parcialmente, por uma instituição governamental com o intuito de alterar determinada situação" (DEUBEL, 2007, p.27, tradução nossa). 
Partindo, portanto, desta perspectiva aprofundaremos nossa compreensão sobre políticas públicas, reconhecendo que "afetam profundamente a vida diária de cada ser humano na sociedade" (THEODOULOU, 1995, p.1, tradução nossa).

Recorremos, inicialmente, à célebre afirmação de Laswell, feita sob o título de seu livro $^{17}$, publicado em 1936, para quem analisar políticas públicas implica responder ao questionamento "quem ganha o quê, quando e como", evidenciando que as políticas públicas geram, em momento específico, benefícios a partir de ações determinadas. Nesse sentido, as políticas públicas dispõem sobre "o que fazer, aonde chegar e como fazer". Resultado da atividade política, envolvem mais de uma decisão, implicando ações estratégicas para alcançar o objetivo desejado, assim, constituem conjunto de ações que buscam alterar dada realidade (RODRIGUES, 2011, p.52).

Em face disso, tem-se que ações são empreendidas para o enfrentamento de determinado problema público e que as políticas são constituídas pela intencionalidade pública visando resposta a este problema. Portanto, propõe-se a tratar ou resolver um problema entendido como coletivamente relevante, que existe quando uma situação é considerada inadequada e há a expectativa de se alcançar condição melhor. Ou seja, o problema público é a diferença entre a situação atual e uma situação ideal almejada para a realidade pública (SECCHI, 2011, p.2, 7).

No âmbito da Administração pública, as políticas são tidas como sistema de decisões públicas, visando à ação ou omissão, podendo ser preventivas ou corretivas, bem como destinarem-se a manter ou modificar a realidade de um ou vários setores da vida social, o que se dá por meio da "definição de objetivos e estratégias de atuação e da alocação dos recursos necessários para atingir os objetivos estabelecidos" (SARAVIA, 2007, p. 29).

Para Bucci (2006, p.39), livre-docente em Direito e secretária de Educação Superior do Ministério da Educação brasileiro, entre os anos de 2008 e 2010, a política pública definese como

[...] o programa de ação governamental que resulta de um processo ou conjunto de processos juridicamente regulados - processo eleitoral, processo de planejamento, processo de governo, processo orçamentário, processo legislativo, processo administrativo, processo judicial - visando coordenar os meios à disposição do Estado e as atividades privadas, para a realização de objetivos socialmente

\footnotetext{
${ }^{17}$ Laswell, Harold. Politics: who gets what, when, how. Cleveland: Meridian Books, 1936.
} 
relevantes e politicamente determinados. Como tipo ideal, a política pública deve visar a realização de objetivos definidos, expressando a seleção de prioridades, a reserva de meios necessários à sua consecução e o intervalo de tempo em que se espera $\mathrm{o}$ atingimento dos resultados.

Logo, a política pública envolve uma escolha da autoridade instituída por fazer, não fazer e como fazer algo acerca de uma questão coletiva e, em um sistema efetivamente democrático, tal escolha deve refletir a vontade da maioria. Portanto, vale destacar que, embora quem enuncie as decisões seja o governo, elas devem ser reflexo do desejo da sociedade para quem este delibera. Assim, a sociedade não pode ser mero público-alvo das ações governamentais, ela deve ser também atriz da tomada de decisões. Isto é fundamental para que as políticas públicas se deem, de fato, no sentido de resolver o problema que é público e, portanto, diz respeito a todos.

Da mesma forma que a escolha por modificar algo, manter determinada situação também constitui uma decisão política. Logo, as decisões "negativas", assim como as "positivas", devem ser deliberadas (HOWLETT; RAMESH; PERL, 2009, p.5). Nessa perspectiva, a inação não corresponde simplesmente à ausência de decisão sobre determinado problema, mas, sim, ao fato de que certas questões não entrarão para o rol das preocupações oficiais.

Refletir sobre a trajetória das ações oficiais em torno da biblioteca escolar em nosso país permite afirmar que as decisões se deram, sobretudo, no sentido da inação, já que, embora simbolicamente considerada importante, ao longo dos anos pouco se fez pelo seu desenvolvimento.

A inação encontrou abrigo nas próprias limitações que se impuseram à biblioteca escolar enquanto problema público ${ }^{18}$, uma vez que, com pesar, é possível constatar que, se no século XIX biblioteca escolar resumia-se a um acervo de materiais para leitura, em pleno século XXI o problema público circunscreve-se de modo semelhante no texto legislativo: a disponibilidade de recursos informacionais de diferentes ordens, como se o mero fornecimento de acesso a informações caracterizasse por si só uma biblioteca escolar. Reduzida a um acervo organizado de informações, sua ausência não é, de fato, sentida por todos como problema público, e assim, é difícil imaginar uma mobilização coletiva em prol do desenvolvimento de bibliotecas escolares, fundamentais à consolidação de sociedades

\footnotetext{
${ }^{18}$ Mais adiante abordaremos o problema público, no âmbito das políticas públicas.
} 
democráticas, na medida em que também se ocupassem de saberes e fazeres relativos ao ato de informar-se.

Nesta urdidura, vale ressaltar que como categoria jurídica, a lei é caracterizada por sua generalidade e abstração. Por sua vez, as políticas públicas são forjadas para a realização de objetivos estabelecidos, ou seja, as leis são "princípios que descrevem direitos” enquanto as políticas públicas "são proposições que definem objetivos" (BUCCI, 2006, p. 25). Por conseguinte, pode-se considerar o direito, as leis e as instituições estatais, como intenção formal de modificar dada realidade; enquanto as políticas públicas - embora compreendam as leis e regulamentações - podem ser entendidas, em certo sentido, como programas de ação, representando a realização concreta das decisões tomadas (DEUBEL, 2007, p. 19).

Face a isso, a atual conjuntura da biblioteca escolar brasileira mostra-se complexa, pois se por um lado há uma lei federal que a coloca como instituição a garantir unicamente o direito de acesso a informações, deixando de lado concepções que contemplem o direito de saber informar-se, por outro, a situação é ainda mais complexa, já que passados mais de quatro anos da sanção da lei, ainda não são identificadas, em âmbito federal, ações que acenem para a realização daquilo que foi designado formalmente.

Diante desta complexa trama, alinhamo-nos ao pensamento de De Certeau (1996, p.214), para quem a política “cria ou recusa condições de possibilidades. Interdita ou permite: torna possível ou impossível". Assim, a toda vontade construtiva são necessários acordos sobre as condições de possibilidade para que se abra um espaço possível a seu desenvolvimento e, uma vez anunciada e assumida a implantação de uma política pública, devem ser criadas as condições de possibilidade para que de fato se desenvolva. A partir disto, propomos a construção de políticas públicas democráticas como caminho para que as bibliotecas escolares saiam da esfera do discurso e façam parte da realidade brasileira, e tendo por base preceitos condizentes com a ordem informacional contemporânea, conforme abordaremos mais adiante neste estudo.

\subsubsection{Política de Governo e Política de Estado}

No bojo de tais reflexões, emerge a importância de distinguir políticas públicas de governo e políticas públicas de Estado. Em breves linhas, é possível sintetizar políticas de 
Estado como aquelas que são perenes, independentemente das mudanças de governo, enquanto políticas de governo são formuladas por uma gestão específica, podendo ser descontinuadas ou alteradas pelo próximo governo (GONZÁLEZ-SUÁREZ, 2008, p. 151). No entanto, ambas estão sujeitas ao ordenamento jurídico de seu país e devem ter como finalidade o interesse público bem como promover e proteger os direitos humanos.

A caracterização deve levar em consideração três elementos básicos: os objetivos da política pública, a sua forma de elaboração, planejamento e execução e, por fim, seu modo de financiamento (AITH, 2006, p.235).

No âmbito dos objetivos, é possível afirmar que uma política é de Estado quando o que se busca com sua implementação é o alcance de finalidades essenciais ligadas à organização política e social. Logo, políticas de organização estrutural de serviços públicos básicos são políticas de Estado. Para ilustrar, no caso brasileiro, aludimos ao Sistema Único de Saúde (SUS) como objeto de uma política de Estado, pois, conforme a Constituição Federal, o Estado deve organizar uma rede de serviços públicos apta a propiciar à população o acesso integral, universal e gratuito à saúde.

A política de governo, de outro lado, pode ser pontual, ter maior flexibilização e especificidade em seus objetivos; sua ação se dá por meio do uso da estrutura estatal e dos mecanismos democráticos já estabelecidos. Como exemplo, uma política de implementação de um Programa de Saúde da Mulher é uma política de governo, pois está inserida no âmbito da consolidação do SUS e utiliza-se de uma estrutura estatal já existente. Desse modo, podem existir outros modelos de prestação desse serviço de saúde pública inseridos no âmbito do SUS (AITH, 2006, p. 235-236).

Outro elemento que auxilia na diferenciação entre política de Estado e de governo refere-se aos atores aptos a promover a sua elaboração, planejamento e execução. Assim, grosso modo, políticas de Estado são realizadas exclusivamente pelo governo. Embora seja possível contar com a participação da sociedade civil na implementação dessas políticas, sendo que isto se dá de forma complementar e subordinada ao Estado. Além disso, devem ser perenes e não podem sofrer rupturas com a troca de governantes. Já políticas de governo podem ser delegadas ou terceirizadas bem como sofrer rupturas em seu andamento (AITH, 2006, p.237). 
Políticas de Estado são financiadas exclusivamente com recursos públicos, provenientes da arrecadação de tributos, já as políticas de governo podem empreender recursos privados em sua implementação, desde que com a regulação estatal, como no caso dos serviços públicos terceirizados de gestão das rodovias públicas.

As políticas de governo podem ser consideradas como toda política governamental voltada à satisfação do interesse público que não represente atividade essencial do Estado, podendo ser delegada e/ou terceirizada ou até sofrer quebra de continuidade. [...] As políticas de Estado geralmente estão previstas na Constituição federal, enquanto as políticas de governo podem estar na Constituição ou em outros textos normativos inferiores. Mas essa regra não é absoluta e pode sofrer alterações (AITH, 2006, p. 239).

Tal distinção mostra-se importante aos propósitos deste estudo, em que apresentamos a biblioteca escolar como organismo essencial à sociedade e, portanto, deve ser alvo de ações perenes que garantam sua presença no contexto nacional. Rupturas não podem ocorrer por conta de alterações no governo que, de acordo com critérios momentâneos, determinem o término de algo anteriormente em curso por questões político-partidárias, por exemplo. Para uma educação que de fato proponha interações dialógicas com o conhecimento, a biblioteca não é, de modo algum, descartável; ela é primordial na medida em que possibilita a apropriação de informação e cultura, elemento determinante à participação das pessoas na vida social.

\subsection{EstAdo E SOCIEDAdE CIVIL}

Definida pela natureza dos elos entre Estado e sociedade civil, a democracia pressupõe a constituição de um efetivo espaço público, portanto, ocupado pela sociedade civil e regulado pelo Estado, a partir de laços orgânicos estabelecidos entre ambos (NOGUEIRA, 2004, p.105). Assim, evidencia-se a necessidade de que concepções e articulações entre Estado e sociedade civil sejam repensadas em perspectiva democrática, como condição fundamental para a possibilidade de criação de novos consensos e consentimentos.

Composto por um conjunto de instituições públicas que se relacionam com o complexo social num território delimitado, o Estado "corresponde a um processo cultural e ideal por meio do qual a ideia de um poder não individualizado se concretiza historicamente" 
(BURDEAU, 1970 apud DEUBEL, 2007, p.20, tradução nossa). Embora seja preciso reconhecer o Estado como aparato de dominação que atua de acordo com as classes que dominam a economia e dão sustentação a um projeto hegemônico, segundo Nogueira (2004, p.61), também é fundamental compreendê-lo como um palco de disputas em que a correlação de forças, as ações do corpo social e a organização política dos interesses têm papel determinante.

Nesses termos, aponta-se para a problemática de concepções que resumem o Estado a algo neutro - espaço harmônico em que diferenças seriam resolvidas -, ou à encarnação do mal, mera estrutura destinada à opressão da sociedade. Apesar de toda a problemática que cerca a figura do Estado no momento atual, marcado pela globalização capitalista, ele continua a ser peça fundamental na vida concreta dos povos de todo o mundo. Logo, além de ser assimilado como estrutura de dominação, precisa ser compreendido "como parâmetro ético de convivência e locus para o encontro de soluções positivas para os problemas sociais" (NOGUEIRA, 2004, p.61).

Com isso, tem-se que a questão fundamental do Estado democrático não é de segurança, mas de liberdade; e assim ele torna-se palco de contestações, não podendo fecharse sobre si mesmo no intento de tornar-se o órgão que comanda todos os movimentos do corpo social. O Estado precisa ser reinventado nos dias de hoje como figura indispensável não porque a democracia ou a sociedade civil necessitem de um tutor a lhes orientar, mas sim por ser uma peça-chave para que a democracia se concretize e a sociedade civil torne-se mais autônoma e potente, já que viver democraticamente não é apenas viver sob o poder de todos, mas principalmente sob a construção permanente e conjunta de um todo (CHAUÍ, 1989, p.151; LEFORT, 1991, p.54; NOGUEIRA, 2004, p.67).

Por sua vez, uma reforma em busca de um Estado democrático somente se efetivará na medida em que trouxer consigo uma sociedade civil igualmente democrática, voltada à emancipação e à construção de consensos e hegemonias por meio da interferência dos sujeitos nos espaços em que são tomadas decisões fundamentais sobre os destinos da coletividade. Não pode, portanto, ser fisgada por concepções que traduzam este espaço social como uma organização domesticada e subalterna, um recurso gerencial concebido de forma técnica, como lugar de cooperações e parcerias em que interesses, grupos e indivíduos organizam-se autonomamente tendo em vista transferir recursos e sustentabilidade às políticas públicas (NOGUEIRA, 2004, p. 58). 
Face a isso, destaca-se que a dimensão política da sociedade civil precisa ser construída para que não se reduza a mera justaposição de indivíduos, pois é a partir de tal dimensão que a sociedade civil vincula-se ao espaço público democrático. Portanto, a existência de conflitos entre distintos grupos, interesses e projetos bem como a busca coletiva por soluções, são decisivos à politização da sociedade, já que a política apresenta-se como caminho para a construção de consensos por meio da negociação das diferenças. Nesse sentido, a democracia se concretiza a partir da interdependência entre Estado e sociedade civil (LEFORT, 1991, p. 48; NOGUEIRA, 2004, p. 103).

Desse modo, a sociedade civil precisa estabelecer vínculos estatais, pois ao pretenderse democrática e ativa, deve comportar a produção de "impulsos igualitários e de novas formas de poder, vida e convivência" o que, de acordo com Nogueira (2004, p.59), só tem condição de existência nos "quadros de um Estado e tendo em vista a conquista do Estado".

Se por um lado, aponta-se para a urgência desta perspectiva, por outro, destacam-se as armadilhas que a globalização - marcada pelo império do mercado, acentuação da cultura individualista, difusão em escala e velocidades inéditas de informações - impõe à sua consecução, pois, novamente recorrendo a Nogueira (2004, p.106),

\footnotetext{
As armadilhas do ciberespaço, das estruturas midiáticas, da despolitização e do individualismo nos fazem derrapar: já não sabemos mais como organizar consensos e já não possuímos cidadãos vocacionados para refletir, ponderar e calcular com base em desenhos razoáveis de futuro. A sociedade civil terminou, assim, por se entregar aos interesses particulares mais imediatos que nela convivem de modo concorrencial, não se deixando alcançar por qualquer projeto 'geral': ficou de costas para a política, inviabilizando-se como espaço de produção de consensos democráticos fortes.
}

Em meio a tal cenário em que a própria democracia é convertida em elemento abstrato e o espaço político estreita-se, emerge a afirmação de que a política, como condição de possibilidade, é a política dos protagonistas organizados, que participam da construção de desenhos razoáveis para o futuro coletivo. Nessa perspectiva, coloca-se a biblioteca escolar como organismo importante a participar de tal projeto, na medida em que estiver de fato comprometida com uma educação para a formação de protagonistas, sujeitos críticos e criativos.

Assim, se a política é o campo em que é possível desejar e lutar por um projeto de futuro, reforçamo-la como caminho para o desenvolvimento de bibliotecas escolares no cenário nacional. Para tanto, deve ser resgatada, reformulada e trazida para o seio da 
sociedade civil, a qual deve ser o coração do Estado democrático, pulsando aspirações e decisões coletivas para todo o corpo social.

Tal proposta evidencia, portanto, que para a consolidação da sociedade civil como meio de predisposição coletiva, espaço para a organização de novas formas de Estado e de comunidade política, de hegemonia e distribuição de poder, é preciso, além de uma perspectiva que colabore para politizá-la, um Estado igualmente democrático, que não esteja entregue aos interesses do mercado e encare a política como espaço de mediação e construção de alternativas para os problemas que afligem a coletividade. Logo, à consecução de tal propósito é fundamental que o papel da política seja valorizado, pois é ela a "fibra mais sensível e mais visível da conexão entre o Estado, a economia e a sociedade" (IGLESIAS, 2000 apud NOGUEIRA, 2004, p. 65).

\subsection{O Sujeito e a ParticipaÇão Política}

Definida como "um espaço institucional que protege os esforços do indivíduo ou grupo para se formarem e se fazerem reconhecer como sujeitos", a democracia não pode ser tomada como a mera participação em uma ordem política que age sobre o corpo social (TOURAINE, 1996, p.173). Portanto, trata-se do reconhecimento da existência de sujeitos pessoais marcados pela diversidade, pressupondo a liberdade para que construam os limites às liberdades coletivas. Assim, é sob o signo da constituição de sujeitos que se coloca a questão da democracia e de uma política que, de fato, estabeleça conexões entre Estado e sociedade.

Nesses termos, evidencia-se o sujeito como aquele indivíduo que se constrói enquanto ator social, constituindo assim o esforço de integração de conhecimentos técnicos/especializados - indispensáveis em um mundo marcado pela técnica-, com a memória e a imaginação, essenciais para que a história - de um e de todos - seja construída em oposição à mera reprodução de uma ordem encerrada sobre si mesma. Tal afirmação não se faz possível em um vazio social, requer condições institucionais que são a própria definição da democracia. De acordo com Touraine (1996, p.11),

[...] trata-se de aprender a viver juntos com nossas diferenças, construir um mundo que seja cada vez mais aberto e possua também a maior diversidade possível. Tanto a unidade [...] quanto a diversidade [...] não devem ser sacrificadas uma à outra. 
De fato, a ideia de sujeito corresponde ao ator que é capaz de transformar seu meio ambiente; atribuir sentido pessoal às suas experiências, resistindo às dominações impostas sejam psicológicas ou políticas -; reconhecer os outros seres humanos como sujeitos e, consequentemente, apoiar ordenamentos políticos e jurídicos que proporcionem ao mais elevado número de pessoas o máximo de oportunidades de viver enquanto sujeitos (TOURAINE, 1996, p.172).

Se, por um lado, ser sujeito implica uma participação construtiva nas decisões que afetam a coletividade, indo muito além do direito ao voto, por outro, observam-se entraves para tanto, já que atualmente o indivíduo está praticamente separado de si mesmo por obstáculos que se impõem à formação de uma experiência. Conforme alerta de Nogueira (2004, p.122), o progresso acelerado vem produzindo "uma espécie de obsolescência prematura generalizada". Assim, a velocidade dos acontecimentos, mudanças incessantes nos equipamentos, formas de trabalho e conhecimentos impõem às nossas vidas ritmo e estrutura marcados pela rapidez e novidade; além do que, somos insistentemente bombardeados por informações que nos tomam de assalto.

Neste contexto, em que a velocidade foi convertida em valor, o espaço para uma reflexão crítica e criadora - que necessita de um ritmo mais lento e processual - nos tem sido furtado por um modelo de mundo que, sob o signo da agilidade, resume-se ao consumo em detrimento das relações sociais. Desse modo, muito se passa diante de nós, porém, pouco se passa conosco, muito pouco nos acontece. Num cenário de sobreposição de acontecimentos, não nos detemos em reflexões sobre projetos coletivos ao nosso futuro, as conexões advindas com as tecnologias de comunicação não implicam necessariamente num estreitamento de relações com o outro, e nossa atuação nos desenhos de um futuro coletivo acaba circunscrita a simples participação em uma ordem política já estabelecida que age sobre o corpo social.

Diante disto, uma sociedade de sujeitos implica a construção de espaços democráticos, pois ninguém nasce sujeito ou assim se constrói por vontade divina. Ser sujeito e participar ativamente de transformações na realidade se faz possível na medida em que houver sinais de reconhecimento e acordos tácitos sobre as condições de possibilidade para a abertura de um espaço em que tal proposta possa se desenvolver (DE CERTEAU, 1995, p.34).

Por conseguinte, reafirma-se novamente a importância de uma reforma de concepções e relações entre Estado e sociedade, governante e governado, política e economia, para que o fazer político não seja resumido, aos olhos da sociedade, a um espetáculo visto por uma 
plateia passiva que, colocada na última fila, observa descrente o desenrolar de ações com a certeza de que destas não advirão transformações positivas ao corpo social.

No bojo de tais reflexões, coloca-se a urgência da construção de espaços que sob uma perspectiva democrática estejam ocupados com a formação de sujeitos, protagonistas das ações e decisões que afetam os rumos da coletividade. Nesse sentido, e conforme Nogueira, a participação política, enquanto recurso de transformação social e reinvenção do político, somente poderá avançar se

[...] seus cidadãos forem alcançados por processos fortes de educação política, de conscientização cívica e de politização. Esses cidadãos não são apenas seus protagonistas principais: são sua garantia. São requisitos dela e produtos dela. Cidadãos ativos, afinal, portadores de direitos e de deveres, mas, concomitantemente, construtores de 'bons governos' e da 'boa sociedade', dependem tanto de instituições políticas e de marcos jurídicos adequados quanto de condições adequadas de participação na esfera pública. Requerem, em suma, procedimentos e atos participativos (NOGUEIRA, 2004, p.163-164, grifo do autor).

Por estas vias, de forma objetiva e categórica destaca-se que para a consolidação e dinamização da cidadania e dos variados direitos humanos é preciso que haja participação política, o que se dá a partir da figura do sujeito, protagonista que interfere no mundo com liberdade e responsabilidade. Para tanto, a construção de um efetivo espaço público se faz urgente e, com isso, emerge a importância de instituições que atuem na perspectiva de formar sujeitos críticos e participativos, questionadores do mundo em que vivem.

Assim, ao lado de outros organismos, apontamos o papel inalienável que pode ter a biblioteca escolar na medida em que for capaz de promover interações do indivíduo com o conhecimento, comprometida com o direito do indivíduo de informar-se e relacionar-se com a informação e a cultura em perspectiva crítica e criativa.

\subsection{O Ciclo da Política Pública}

A compreensão de elementos procedimentais envolvidos na formulação de políticas públicas torna-se importante na medida em que auxilia no entendimento daquilo que está implicado neste fazer coletivo que tem em vista transformar determinada situação. Desse modo, ao mapa até então traçado para subsidiar a análise do desenvolvimento de políticas públicas para bibliotecas escolares é acrescido tal viés e, a partir da constatação da existência 
de diferentes modelos explicativos com enfoques variados ${ }^{19}$, filiamo-nos à proposta do Ciclo da política pública que coloca as políticas como processo composto por um conjunto de atividades com vistas a atender às demandas e interesses da sociedade.

Propondo a política pública como um ciclo deliberativo, composto por distintas fases sequenciais e interdependentes que constituem um processo dinâmico, o Ciclo da política pública é, sobretudo, um recurso voltado à análise de políticas públicas; não caracteriza uma estrutura a ser rigidamente seguida em sua elaboração. Isso porque raramente reflete a dinâmica de uma política pública, pois frequentemente as fases se misturam e se alternam, e o processo pode ser iniciado em momentos distintos ou, ainda, não apresentar alguma das fases. Além disso, tais fases estabelecem inter-relações, implicando um sistema de influências entre si. Nessa perspectiva, em síntese, o Ciclo da política pública é uma tipologia ideal que sugere a compreensão das políticas públicas a partir de uma sucessão de fases, com seus distintos cenários e atores (DEUBEL, 2007; RODRIGUES, 2011; SECCHI, 2011).

Entre as críticas a essa proposta, estão a dificuldade de se estabelecer na prática a separação entre as fases, a incerteza do processo da política pública, a incapacidade do modelo em explicar que condições levam de uma fase a outra, a tendência a situar a avaliação somente ao fim do processo e a dar maior peso à fase da decisão (DEUBEL, 2007, p. 52-54). Apesar das limitações apresentadas, consideramos o modelo interessante - sobretudo quando somado às reflexões levantadas neste capítulo -, pois apresenta a política pública, de fato, como um processo, e simplifica sua complexidade ao decompô-la em fases, permitindo estudar separadamente as particularidades que compõem a dinâmica como um todo. Além disso, o modelo é suficientemente amplo, o que viabiliza sua utilização para compreender políticas de distintas naturezas e variações.

Em relação às fases que constituem o processo político ${ }^{20}$, alinhamo-nos à categorização apresentada por Theodoulou (1995): reconhecimento do problema e

\footnotetext{
19 Conforme Souza (2010) evidencia: Lindblom (1979), Caiden e Wildavsky (1980) e Wildavsky (1992), desenvolveram o modelo do Incrementalismo. Cohen, March e Olsen (1972), o Garbage can; Sabatier e JenkinsSmith (1993), o modelo Coalizão de defesa; Baumgartner e Jones (1993) lançaram o modelo do Equilíbrio interrompido. Há, ainda, o modelo de Arenas sociais, dentre outros.

${ }^{20}$ Embora haja alguma diferenciação entre as fases propostas por diferentes autores, observamos que, por vezes, a existência de uma fase a mais em dada proposta não significa, necessariamente, que aquele elemento não é considerado na proposta de outro autor, que poderá ser contemplado em conjunto com elementos de outra fase. A seguir algumas propostas: Secchi (2011) sugere sete fases principais: identificação do problema, formação da agenda, formulação de alternativas, tomada de decisão, implementação, avaliação, extinção. Já Howlett, Ramesh e Perl (2009) colocam cinco fases: agenda setting, formulação das alternativas, tomada de decisão, implementação, avaliação. Jones (apud Deubel 2007) propõe cinco fases: identificação do problema, formulação
} 
delimitação da questão, agenda política, formulação de alternativas, tomada de decisão, implementação, monitoramento e avaliação. A seguir discutiremos cada fase no intuito de compreender suas implicações, lembrando que, embora apresentadas separadamente, são interdependentes.

\subsubsection{Reconhecimento do Problema e Delimitação da Questão}

A formulação de políticas públicas se dá pelo reconhecimento de um problema e por sua delimitação como questão a ser alvo de ação política. Essa fase inicial constitui processo pré-decisório do Ciclo da política e é momento fundamental, pois distintos atores entrarão em confrontos e negociações para determinar quais os problemas que, efetivamente, serão incluídos na agenda governamental.

É nessa fase que se colocam reflexões sobre quais os elementos que fazem chegar o momento de se considerar determinado problema; reflexão inserida em questionamento ainda maior acerca daquilo que faz com que alguns temas sejam, em dado momento, alvo de atenção enquanto outros não (KINGDON, 2007, p.219).

Nesse sentido, analisar essa fase implica compreender por meio de quais mecanismos um tema torna-se problemático e objeto de intervenção do Estado, já que transformar uma situação de dificuldade em problema público é condição primeira para que uma questão dê origens a uma política pública.

Em face disso, destaca-se a distinção entre uma situação e um problema, pois, cotidianamente várias situações tidas como não ideais são toleradas pelas pessoas, entretanto, não ocupam lugar prioritário na agenda política (KINGDON, 2007, p.227-228). São as formas pelas quais essas situações foram definidas, aliadas ao seu reconhecimento pelas autoridades governamentais, que determinarão sua condição de problema público bem como a atenção que receberá, a partir da inserção de questão específica na agenda política.

de soluções, tomada de decisão, implementação e avaliação. Souza (2010) argumenta pela definição da agenda, identificação de alternativas, avaliação das opções, seleção das opções, implementação e avaliação. Rodrigues (2011) indica: preparação da decisão política, agenda setting, formulação, implementação, monitoramento, avaliação. 
A consciência de que as questões públicas são delimitadas a partir do reconhecimento de dada realidade como problemática coloca-nos frente à constatação de Deubel (2007, p.58, tradução nossa), para quem os problemas são representações, resultado do "conjunto de negociações que atores sociais e políticos empreendem para impor uma leitura do problema que seja a mais vantajosa aos seus interesses". Assim ocorre com a biblioteca escolar, pois enquanto uns podem afirmar que sua ausência resume-se ao problema da falta de recursos informacionais, outros apontam para a necessidade da constituição de dispositivos que extrapolem tal dimensão, ocupando-se com ações voltadas à apropriação da informação e cultura.

Diante disto, Cobb e Elder (1995, p.96-97) afirmam que há quatro maneiras para a formação da questão. Assim, podem ser criadas por sujeitos que, permeados pela democracia, visam transformações positivas para a coletividade em que se inserem. Outra forma se dá em decorrência de situações imprevisíveis, um desastre natural, por exemplo. Por sua vez, não é possível deixar de indicar o reajuste, quando questões são criadas por grupos específicos que desejam alterar determinada situação tida como desfavorável para si. Além disso, tem-se também a exploração que, distanciada de uma perspectiva de construção coletiva, ocorre na medida em que pessoas ou grupos criam questões tendo em vista vantagens para si.

Por essas vias, tem-se que a identificação da questão envolve: a percepção de uma situação pública insatisfatória; a delimitação do problema em conjunto com os norteadores para definir causas, soluções, culpados, obstáculos; a avaliação da possibilidade de resolução, ou seja, para que um problema seja identificado socialmente e entre para a agenda política, ele deve ser acompanhado de uma solução, mesmo que esta não busque resolvê-lo por completo, mas, apenas mitigá-lo (SECCHI, 2011, p.35).

Portanto, para o reconhecimento do problema e delimitação da questão é preciso que ocorram transformações na vida cotidiana das pessoas em decorrência de situação que gere tensão, a partir da qual será reconhecida, explícita ou implicitamente, uma situação como problemática. Contudo, aquilo que foi inicialmente sentido como problema individual precisa ser alçado à posição de problema coletivo para que entre para a agenda política. Para tanto, além da necessidade de sujeitos interessados em explicitar um problema, é preciso que este seja externalizado, ressaltando-se aqui a relevância dos meios de comunicação, comunidades científicas, acadêmicos e atores institucionais. Após o reconhecimento e formulação do problema como público, ocorre a busca por institucionalizá-lo, a partir da intervenção política 
que, grosso modo, traduz-se em leis e regulamentações com o intuito de legitimar a questão delimitada (DEUBEL, 2007, p.59).

Nesse sentido, coloca-se que a capacidade de dimensionar um problema é primordial para que se dê a efetiva intervenção do Estado em busca de soluções, e certas questões podem auxiliar nessa tarefa. Tais questões envolvem: a natureza do problema; suas causas e contextos; a duração, ou seja, se o problema é passageiro ou duradouro; a dinâmica, se é possível observar uma evolução do problema; os afetados, pessoas ou grupos direta e indiretamente envolvidos e sua situação; as consequências, em termos de ocorrências, caso não haja intervenção. Refletir sobre esses questionamentos é importante para compreender como o problema se constitui e, também, para verificar as interações entre os distintos elementos e atores nele implicados (DEUBEL, 2007, p. 60).

Conforme Deubel (2007, p. 60, tradução nossa), o dimensionamento de problemas públicos é tarefa que "deveria ser seriamente assumida pela administração pública, universidades e centros de pesquisa com o objetivo de proporcionar informações que permitam conhecer melhor o problema antes que se tome uma decisão relativa à necessidade e forma de regulação pública”. Face a isso, ressalta-se a importância de que tais circuitos empreendam discussões em torno da questão biblioteca escolar tendo em vista lançar subsídios a construção de caminhos para seu desenvolvimento em perspectiva que contemple as relações inextrincáveis entre informação e educação para a formação de sujeitos.

Isto posto, reforça-se que o reconhecimento de problemas é passo crítico para a segunda fase do processo, o estabelecimento da agenda política. A interpretação e a delimitação do problema público como um alvo de ação política são determinantes para a forma como o problema será abordado pela política pública. Assim, conforme mencionado, o problema da ausência de bibliotecas escolares poderá receber tratamento totalmente diverso, de acordo com a maneira pela qual for interpretado.

\subsubsection{Agenda Política}

A agenda política é o conjunto de temas que são objeto de discussão pública, sendo determinada em um processo vinculado às características do sistema político, às dinâmicas das relações de poder e às relações existentes entre Estado e sociedade civil. Portanto, a 
agenda política tem início no momento em que a existência de um problema é de fato reconhecida pelo Estado e soluções são buscadas para tanto (COBB; ELDER, 1995, p.88).

A agenda é:

[...] a lista de temas ou problemas que são alvo em dado momento de uma séria atenção, tanto da parte das autoridades governamentais como de pessoas de fora do governo [...].Dentro dos possíveis temas ou problemas aos quais os governantes poderiam dedicar sua atenção, eles se concentram em alguns e não em outros. Assim, o processo de estabelecimento da agenda reduz o conjunto de temas possíveis a um conjunto menor, que de fato se torna foco de atenção (KINGDON, 2007, p.222).

A agenda não compreende um documento formal, mas, sim, o conjunto de questões que são alvo da atenção do governo. Trata-se de uma construção política sujeita a mudanças devido a eventos ou situações novas. Nesse contexto, devemos atentar para a distinção entre dois tipos básicos de agenda, explicitados por Cobb e Elder (1995, p.99). Um deles é a agenda sistêmica, que compreende todos os assuntos percebidos pela comunidade política como dignos de atenção pública. Já a agenda institucional pode ser definida como o conjunto de itens levados para o campo da ação e seriamente considerados pelos políticos. Portanto, inicialmente as questões inserem-se na agenda sistêmica e, caso obtenham suficiente atenção, são movidas para a agenda institucional, um subconjunto da primeira. Entretanto, limitações como tempo, recursos e até mesmo interesse fazem que um número limitado de questões entre na agenda institucional.

Nem todos os problemas são incluídos na agenda política, o que demonstra a existência de mecanismos, nem sempre evidentes, de exclusão e inclusão na pauta de prioridades. Para que um problema seja inscrito na agenda política são necessárias três condições básicas: atenção, ou seja, diferentes atores devem entender a situação como digna de intervenção política; competência, a questão deve ser responsabilidade das autoridades públicas; resolubilidade, possíveis ações devem ser encaradas como necessárias e factíveis (COBB; ELDER, 1995).

A inserção de problemas na agenda política, grosso modo, provém de duas fontes. A primeira é externa ao Estado e suas instituições, constituindo o modelo da demanda, em que diferentes grupos mobilizam-se para requerer a intervenção estatal. Obviamente, cada grupo, que não está em posição de igualdade, pressionará as autoridades por meio de estratégias específicas e a partir dos recursos de que dispõe. A segunda, o modelo da oferta 
administrativa, é interna ao Estado e às suas instituições, ou seja, os problemas a serem inseridos na agenda são delimitados pelos atores-institucionais (DEUBEL, 2007, p.62).

A inserção de problemas na agenda política, grosso modo, provém de duas fontes. A primeira é externa ao Estado e suas instituições, constituindo o modelo da demanda, em que diferentes atores e grupos mobilizam-se para requerer a intervenção estatal. A segunda, o modelo da oferta administrativa, é interna ao Estado e suas instituições, ou seja, os problemas a serem inseridos na agenda são delimitados pelos atores-institucionais (DEUBEL, 2007, p.62).

A literatura evidencia que a agenda política é influenciada por desdobramentos na esfera política. Assim, uma mudança no governo pode alterar profundamente a agenda ao enfatizar concepções diversas dos problemas e, também, o novo governo pode deixar de conceder atenção a alguma questão que não seja tida como prioritária. Além disso, grupos de oposição podem dificultar que certas questões sejam contempladas pela ação política e, nesses termos, Kingdon (2007, p.227) evidencia que na dinâmica da política pública os consensos são formados por meio da negociação e não da persuasão.

Com relação à biblioteca escolar, é possível constatar que em nosso país apenas recentemente esta se insere na agenda política federal, o que se deu com a criação da Lei $n^{\circ}$ 12.244/10. Assim, se por um lado foi explicitada como direito a ser garantido em lei, por outro, passados mais de quatro anos da sanção do texto legislativo não há indícios de ações empreendidas pelo Estado para que tal direito se concretize. Com isso, evidencia-se que a biblioteca escolar ainda não foi alçada à agenda institucional, ou seja, não faz parte do corpo de questões que são alvo de ação concreta, pois a intenção exposta na legislação permanece simbólica.

\subsubsection{Formulação de Alternativas}

A fase de formulação de alternativas é focada no desenvolvimento de cursos de ação factíveis para lidar com o problema público inserido na agenda política. Idealmente, contempla o estabelecimento de objetivos e estratégias bem como a análise das possíveis consequências advindas de cada alternativa proposta. Assim, corresponde à formulação de 
alternativas distintas para tratar de determinado problema que, posteriormente, serão reduzidas a um conjunto menor de opções de cursos de ação a ser analisado pelos políticos.

De acordo com Cochran e Malone (1999 apud SIDNEY, 2007, p.79), nesse momento emergem questões como: "Qual o plano para tratar do problema? Quais são os objetivos e prioridades? Quais são as opções disponíveis para alcançar estes objetivos? Quais são os custos e benefícios de cada opção? Quais fatores externos, positivos e negativos, estão associados com cada alternativa?”. Nesses termos, solucionar um problema público implica realizar um diagnóstico do mesmo, conhecendo detalhadamente suas causas e consequências para, com isso, identificar e desenvolver alternativas possíveis. Para Schattschneider (1960 apud SIDNEY, 2007, p.79), "a definição das alternativas é o instrumento supremo de poder, porque a definição de alternativas é a escolha dos conflitos, e a escolha dos conflitos aloca o poder", ou seja, as alternativas propostas aos decisores políticos ${ }^{21}$ exercem influência direta na decisão política final.

Nesse processo, em que são propostas soluções com vistas a diminuir a distância entre uma situação problemática atual e a situação almejada, é primordial ter clareza quanto às metas a serem alcançadas para, em seguida, definir os objetivos concretos que irão viabilizar a realização destas. A definição de objetivos é o momento em que os atores envolvidos no processo irão resumir aquilo que esperam como resultado da política pública, e, quanto mais concretos, mais precisa será a constatação da eficácia da política pública. Contudo, por vezes o estabelecimento de metas é tarefa complexa, como nos casos em que se devem considerar elementos qualitativos, ou ainda, quando as metas são politicamente indesejáveis devido às baixas probabilidades de se obter sucesso (DEUBEL, 2007, p. 77; SECCHI, 2011, p. 37).

Face a isso, o estabelecimento de objetivos é importante para nortear a construção de alternativas que, mediante um processo de seleção, serão reduzidas até se chegar a um conjunto que irá receber séria consideração por parte dos decisores políticos (DEUBEL, 2007, p.76).

A geração de alternativas, via de regra, contará com as comunidades de especialistas, aí incluídos acadêmicos, consultores, pesquisadores, analistas ligados à esfera institucional e

\footnotetext{
${ }^{21}$ Em inglês, policy makers e decision makers, conforme Kingdon (2003); Howlett, Ramesh e Perl (2009); Theodoulou (1995); Cobb e Elder (1995); Sidney (2007). Em português, Souza (2010) emprega os termos decisores de políticas bem como decisores, todavia, tais termos são sucedidos pelo equivalente em inglês: policy makers. Optamos pelo emprego do termo decisores políticos, pela ausência em nosso léxico de termo equivalente àqueles do idioma inglês.
} 
também aqueles que trabalham para grupos de interesse. Tais atores podem atuar tanto como incentivadores ou enquanto obstáculos a certos encaminhamentos, assim, podem empreender esforços para que uma alternativa seja considerada a mais adequada como também podem interpor obstáculos, reduzindo as chances de determinadas opções propostas (KINGDON, 2007, p. 219-223).

Assim, embora seja o governo a instância que de fato toma decisões, determinando prioridades, metas, objetivos e metodologias para abordar um problema público, há um número plural de atores que pesam na configuração do problema. Nesse sentido, Deubel (2007, p.73) argumenta que a influência desses atores explica o motivo pelo qual as alternativas escolhidas nem sempre são as mais coerentes; importando mais o resultado do embate entre as instâncias implicadas nesse jogo.

Portanto, reforça-se a relevância da participação da sociedade civil nesta fase que determina rumos para a construção do futuro, já que tal participação é fundamental para garantir a consolidação da democracia e para que as alternativas para tratar determinado problema público sejam construídas tendo em vista melhorias para o corpo social, e não para este ou aquele grupo específico.

Destarte, emerge a importância de que esteja claro qual o objetivo almejado com o desenvolvimento de bibliotecas escolares, pois é a partir daí que serão traçados cursos de ação.

Nesses termos, estando a formulação de alternativas atrelada à delimitação da questão, é evidente que a forma como o problema biblioteca escolar foi concebido determinará o rumo a ser trilhado. Na medida em que se constata que o problema da ausência de bibliotecas escolares inscreve-se na Lei Federal $n^{0} 12.244 / 10$ como um problema de carência de acesso a recursos informacionais, parece que a alternativa a ser proposta poderá circunscrever-se a ações que garantam o direito de acesso à informação. Novamente, então, desponta a importância de que a questão seja rediscutida a partir da ideia democrática que apresenta a urgência de que as pessoas, além do direito ao acesso à informação, tenham o direito de saber informar-se, de apropriar-se do universo de signos em perspectiva crítica e criadora. 


\subsubsection{Tomada de Decisão}

A tomada de decisão está intrinsecamente relacionada à fase anterior, já que a decisão se dará a partir das alternativas previamente elencadas. Assim, compreende a escolha, dentre um conjunto reduzido de opções, de uma alternativa para tratar do problema público ou, ainda, a opção por não aprovar nenhuma das propostas como curso de ação oficial (HOWLETT; RAMESH; PERL, 2009, p. 139).

As decisões podem ser positivas, negativas ou, ainda, não haver decisão. As decisões positivas são aquelas que, uma vez implementadas, buscam interferir no problema público de alguma maneira; já as decisões negativas ocorrem no sentido de manter determinada condição, ou seja, ocorrem quando o governo delibera que não agirá sobre o problema; por fim, pode haver a ausência de decisão (non-decisions), quando alternativas para alterar determinado problema nem chegam a ser consideradas, ou seja, a questão não foi objeto de interesse nas fases da agenda política e da formulação de alternativas.

Em nossas reflexões sobre o desenvolvimento de políticas públicas para bibliotecas escolares destacamos a afirmação de Howlett, Ramesh e Perl (2009, p. 141, tradução nossa) para quem "embora a substância das decisões possa ser infinitamente variada, seus efeitos fundamentais serão ou para perpetuar o status quo ou para alterá-lo”.

A tomada de decisão então é restrita aos atores-institucionais com autoridade para deliberar: políticos, juízes e outros membros do governo são aqueles com "voz" e "voto" que participam ativamente dessa fase. O que não significa que tenham liberdade para adotar a política que desejam, pois suas ações devem estar circunscritas num contexto permeado por regras que garantam o predomínio do interesse coletivo.

Isto posto, pondera-se que até o momento da decisão, e inclusive mais além, a política

pública é constituída antes de tudo por discursos. É por meio da retórica que os diferentes atores irão argumentar e persuadir, num processo eminentemente social de influências mútuas e de relações de força (DEUBEL, 2007, p. 105). 


\subsubsection{Implementação}

Após a tomada de decisão sobre o problema público, ocorre a implementação, ou seja, a decisão política é posta em execução. Para tanto, são feitas escolhas com o intuito de que os resultados almejados sejam alcançados, assim, a implementação comporta o planejamento administrativo do processo político. Neste ponto irão emergir questões em torno da disponibilidade de recursos, humanos e materiais, para por as ações em prática; clareza dos objetivos da política, procedimentos a serem desenvolvidos, dentre outros elementos.

A implementação não pode ser traduzida puramente como um problema técnico ou administrativo de fácil execução, uma vez que é nesta fase que a política pública, até então circunscrita praticamente a discursos de intenção, irá ser transformada em ação concreta. É neste ponto do processo político que são criados textos normativos (DEUBEL, 2007, p. 107).

Em meio à transformação de intenções em ações concretas, é o corpo administrativo da administração pública que irá implementar a política pública. Apesar da predominância de tais atores institucionais nessa fase, atuando diretamente no processo de consecução da política, ressalta-se a provável presença de outros atores tais como grupos de interesse, prestadores de serviços, fornecedores, etc., que serão incluídos no jogo político-administrativo marcado por manobras que expressam conflitos de interesse (HOWLETT, RAMESH, PERL, 2009, p. 161; SECCHI, 2011, p.46).

Devemos, portanto, considerar a complexidade dessa fase, que não pode, de modo algum, ser reduzida a um fazer técnico, sendo também marcada por embates de interesse; além de comportar a relevância das pessoas, já que é nesse momento que funções administrativas como coordenação e liderança são postas em prática. Ou seja, os atores que lideram a implementação devem ser capazes de compreender e lidar com obstáculos tanto técnicos como legais, num processo constante de negociação com o conjunto de atores aí implicados. No bojo de tais reflexões, emerge o alerta de Deubel, para quem

[...] os objetivos anunciados para justificar uma política não são necessariamente aqueles que se quer alcançar, mas por razões de oportunidade política ou de estratégia, às vezes não convém ao decisor enunciar suas decisões reais. Por exemplo, uma lei pode ter como objetivo a segurança e tranquilidade geral dos cidadãos, mas o decisor busca na verdade vigiar ou controlar as atividades de alguns cidadãos. Igualmente pode suceder que se aprove uma política sem que se pense realmente em implementá-la. Nestes casos, fala-se de política simbólica: o efeito do anúncio serve de política e pode ter efeitos reais. Edelman (1991) mostra como a 
política pode ser um jogo no qual o espetáculo e a construção do cenário são mais importantes que a resolução dos problemas por meio de uma implementação efetiva (DEUBEL, 2007, p.125-126, tradução nossa).

Diante disto, há que se denunciar o problema em torno da Lei $\mathrm{n}^{\circ} 12.244 / 10$, pois ao ser promulgada a partir da luta de atores que reconhecem a importância da biblioteca escolar para a sociedade, mas até o momento não tendo sido objeto da formulação de uma política pública para sua implementação, corre o risco de virar letra morta, ou seja, uma legislação que se traduz como expressão simbólica para acalmar determinados setores da sociedade. Tal problema agrava-se ainda mais a partir da constatação de que em nosso país, de modo geral, a biblioteca escolar é apenas simbolicamente tida importante pela sociedade, a qual não compreende o potencial deste dispositivo para promover melhorias efetivas na vida de cada um. Todavia, torna-se difícil alcançar tal compreensão num cenário em que prevalecem concepções de biblioteca escolar como mero acervo organizado de recursos informacionais.

\subsubsection{Monitoramento e Avaliação}

A fase de monitoramento e avaliação, embora colocada ao final do processo de formulação da política pública, já está presente em momentos anteriores, sendo apresentada separadamente apenas para fins de compreensão das questões implicadas no Ciclo da política pública.

Avaliar e monitorar são atividades essenciais para que o desenvolvimento e os resultados das ações públicas sejam efetivamente conhecidos. Assim, nessa fase emergem questões em torno do êxito da política pública, do alcance dos objetivos propostos por lei, assim como das consequências e custos da política implementada.

É nesse momento que o processo de implementação e o desempenho da política serão examinados, tendo em vista identificar em que medida a política tratou do problema que a desencadeou, portanto, compreende a avaliação dos meios empregados e objetivos alcançados. Assim, monitoramento e avaliação são atividades primordiais para que o governo e os cidadãos tomem conhecimento dos resultados alcançados por meio das ações políticas, permitindo melhoria da percepção sobre a política empreendida, visando seu aprimoramento.

Para haver um processo de avaliação sério, inicialmente é importante definir os objetivos que se buscam por meio da avaliação, já que sua finalidade e as características do 
objeto avaliado irão influir diretamente no modo de avaliar. Conforme Deubel (2007, p.138), “a avaliação só é possível na medida em que seu sentido, assim como a escala de valores utilizada se encontram enunciados com a maior clareza possíveis”. Nessa perspectiva, é fundamental que a avaliação ofereça como resultado elementos pertinentes que permitam compreender os resultados da política pública de maneira precisa, sem espaços para a subjetividade acerca dos efeitos das ações deflagradas.

O processo avaliativo comporta momentos distintos, a saber: a avaliação ex ante, pretérita à implementação; a avaliação in itinere, também conhecida como monitoramento, que se dá ao longo do processo de implementação com fins de ajustes no curso das ações; e por fim a avaliação ex post, ou seja, posterior à implementação.

Ocorrendo previamente à implementação, a avaliação ex ante consiste em analisar a proposta da lei ou programa de governo com vistas a identificar quais os efeitos que sua implementação poderia acarretar. Já o monitoramento irá acompanhar a implementação da política pública, oferecendo possibilidade de alterações nos rumos da implementação, a partir da adequação da proposta em curso com a realidade em que está sendo aplicada. O monitoramento é de extrema relevância, pois permite avaliar se a relação meios/fins é adequada, por meio do acompanhamento do desenvolvimento das ações. Enquanto isso, a avaliação ex post busca analisar os efeitos da ação política após sua implementação, prescindindo do uso apropriado de metodologias qualitativas e quantitativas para compreender, com precisão, os resultados alcançados (DEUBEL, 2007, p. 142; RODRIGUES, 2011, p.51).

Nesse sentido, evidencia-se a importância de definição de critérios, indicadores e padrões para proceder à avaliação. Entendidos como "mecanismos lógicos que servem como base para escolhas ou julgamentos”, os critérios irão fornecer ao avaliador parâmetros para julgar os resultados da política pública. Os mais utilizados referem-se à economicidade que compreende o nível de utilização de recursos; eficiência econômica que contempla a relação entre recursos utilizados e produtividade; eficiência administrativa, ou seja, o nível da execução daquilo que foi preestabelecido; eficácia, correspondente ao alcance de metas e objetivos; e por fim equidade, que trata da igualdade com que a política pública beneficiou, ou puniu, seus destinatários (SECCHI, 2011, p.50).

A operacionalização dos critérios ocorre por meio de indicadores, criados para medir input, output e resultados (outcome). Indicadores de input medem esforços, e assim são 
artifícios criados para avaliar o empreendimento de recursos financeiros, humanos e materiais na ação política. Já indicadores de output medem realizações, referindo-se à produtividade, por exemplo, a quantidade de escolas construídas. Já os indicadores de resultados, outcome, compreendem realizações, relacionam-se à capacidade de resolução do problema público. Por outro lado, os parâmetros irão fornecer uma referência comparativa aos indicadores (SECCHI, 2011, p.51).

Em se tratando da execução da avaliação, esta normalmente é feita por atoresinstitucionais, como políticos e demais membros do governo, todavia, nesta fase também estão presentes organizações não-governamentais, que conformam grupos de interesse e podem desenvolver sua própria avaliação da política pública, o que permite que haja maior transparência acerca dos resultados da política. Destaca-se ainda que os cidadãos, de certo modo, fazem parte da avaliação, ao manifestarem em veículos de informação sua opinião sobre os resultados alcançados pela política e, também, ao explicitarem sua satisfação ou insatisfação por meio do voto nas eleições (HOWLETT, RAMESH E PERL, 2009, p.140).

Ressalte-se que a avaliação está inserida no contexto político do objeto em análise, ou seja, também é um ato político, não estando totalmente isenta de intenções. Portanto, para que seja efetivamente útil à coletividade é primordial que a avaliação tenha credibilidade, apresentando transparência acerca dos critérios, indicadores e parâmetros utilizados para analisar a política pública em toda sua complexidade, não sendo limitada a qualificá-la a partir de viés reducionista, meramente como boa ou ruim. Deve ir além, explicitando os elementos quantitativos e qualitativos alcançados para que, após a análise, os problemas e soluções implicados possam ser, efetivamente, revistos. Com isso, o ciclo da política poderá seguir para outra etapa, com vistas a redimensionar a questão política, ou ainda, manter o status quo. 


\section{IMPLANTAÇÃO DE BIBLIOTECAS ESCOLARES: O PARADIGMA DA APROPRIAÇÃO CULTURAL}

No quadro contemporâneo, marcado pela predominância dos fluxos informacionais mais informações, mais acesso, mais velocidade -, bússolas cognitivas passam a ser categoria indispensável aos processos de educação dos sujeitos.

Ações que visem exclusivamente à democratização do acesso merecem ser revistas, sendo premente o desenvolvimento de novas relações dos sujeitos com o universo signíco, sobretudo para que se deem de forma afirmativa, e não meramente como ato de consumo passivo. Conforme Perrotti e Pieruccini (2013, p.15) alertam, esta perspectiva é fundamental, pois a chamada "era da informação não diz respeito apenas à emergência de novas formas de produzir, distribuir e receber signos. É, sobretudo, um novo modo de nos definir, de ser e de estar, de nos relacionarmos com o mundo".

A tarefa, todavia, não é simples, já que em nossas escolas parece predominar o exercício da repetição, em que o mestre tem a função de transmitir e os alunos devem decorar os conteúdos. Rancière (2011, p.45), observa que na cena escolar, ainda hoje, as "crianças repetem como papagaios. Elas cultivam uma só faculdade, a memória”.

Charlot (2008, p.59) considerou que "nascer é ingressar em um mundo no qual estarse-á submetido à obrigação de aprender", portanto, "ninguém pode escapar dessa obrigação, pois o sujeito só pode 'tornar-se' apropriando-se do mundo". Nesses termos, apropriar-se do mundo não significa somente apoderar-se dele materialmente, é também moldá-lo, transformá-lo; o mundo não é somente um conjunto de significados no qual estamos inseridos, também é horizonte de atividades, espaço e tempo no qual temos um papel a desempenhar.

Desse modo, apropriar-se é ação afirmativa, que contempla invenção e produção de significados, opondo-se à mera recepção mecânica de informações, ou seja, é transformar aquilo que se recebe em algo próprio, a partir de nossas experiências (CHARTIER, 1999).

De um lado, a noção de apropriação veicula a ideia de adaptação de algo a um uso definido, de outro, a ideia de ação tendo em vista tornar alguma coisa sua. Assim, SerfatyGarzon alerta que a apropriação somente é possível em relação a algo, o que não significa exclusivamente a posse jurídica de determinado objeto, e sim a intervenção do sujeito sobre 
alguma coisa. Portanto, embora a propriedade jurídica possa ser um dos elementos da apropriação, não é sua condição ou consequência necessária, pois a apropriação cultural remete a aspectos de ordem psicológica, moral e afetiva do sujeito da apropriação. Nesses termos, Serfaty-Garzon considera que o objetivo da apropriação, "é precisamente o de tornar própria alguma coisa, isto é, de adaptá-la a si e, assim, transformar essa coisa em um suporte de expressão de si” (2003 apud PERROTTI, PIERUCCINI, 2008, p. 72).

Logo, a apropriação cultural envolve processos subjetivos e imateriais que correspondam a uma ação do sujeito sobre o mundo, e implica numa "atuação e afirmação dos sujeitos nas dinâmicas de negociação de significados" (PERROTTI; PIERUCCINI, 2008, p.74). Diante disto, é ato de protagonistas movidos pelo desejo e vontade de apropriarem-se de algo, distinguindo-se, portanto, de usuários e consumidores de informação e cultura.

Então, se por um lado explicitamos a importância de que a apropriação cultural seja referência a pautar o desenvolvimento de bibliotecas escolares, por outro, indicamos ser preciso considerar que a biblioteca é um dispositivo, noção que compreende "toda ação, de elementos humanos ou materiais, realizada em função de um objetivo a ser atendido" (PIERUCCINI, 2004, p.41), bem como a interação entre conjuntos de recursos materiais, simbólicos e relacionais.

Sob tal enfoque, a biblioteca escolar não é mero suporte de informações, isenta de intenções, mas, ao contrário, sua estrutura, seus discursos e modos de interação caracterizam sua intencionalidade, e assim, ela é objeto produzido, que também produz uma finalidade. Conforme Perrotti e Pieruccini (2008, p. 17), ela "reflete e refrata ao mesmo tempo", o que a situa para além de mera posição funcional ou instrumental e permite entrever sua dimensão discursiva, sobressaindo-se, portanto, seu papel nos atos de significação, já que os dispositivos não apenas funcionam, eles significam. Ou seja, as bibliotecas não apenas expressam, mas, também, definem, por meio dos discursos implícitos em sua configuração e formas de relacionamento entre os sujeitos e o universo simbólico que guardam.

Em face desse quadro, o objetivo da apropriação cultural coloca a biblioteca escolar como dispositivo de mediação cultural, o que significa comportar ações "de produção de sentidos e não mera intermediação ou transmissão anódina de signos" (PERROTTI, PIERUCCINI, 2008, p. 84). 
Desenvolver bibliotecas escolares sob esta perspectiva não é tarefa simples, pois não se trata apenas de criar espaços físicos dotados de recursos informacionais. Afirmar a biblioteca como um dispositivo é dizer que tudo nela tem um significado e uma intenção. Nesse sentido, ações a partir do paradigma da apropriação cultural implicam a articulação de variados elementos conceituais:

Transdisciplinaridade: As relações entre os campos da Informação e da Educação, com a articulação de seus saberes e fazeres, é essencial à constituição de bibliotecas escolares. A biblioteca escolar não é organismo desintegrado do âmbito educativo; constitui-se como dispositivo privilegiado de informação e cultura, articulado ao aprendizado.

Protagonismo cultural: O protagonista cultural é o sujeito que atua afirmativamente nos processos simbólicos, apropriando-se de informação e cultura. Em seu relacionamento com o conhecimento, ele influencia e é influenciado. Para tanto, o diálogo com o conhecimento em perspectiva criadora, considerando experiências e vínculos com uma história, é elementochave (PERROTTI, PIERUCCINI, 2008).

Desejo: O desejo de saber advém quando o sujeito experimenta o prazer de aprender e, por conseguinte, conhecer. Nesta perspectiva, estimular o prazer implica reconhecer um sujeito que não é esvaziado de sentidos e sentimentos, mas, se constitui a partir de experiências, referências e tem uma história repleta de significados que não podem ser desconsiderados (CHARLOT, 2008, p.81).

Saberes informacionais: "Conjunto complexo de habilidades, competências e atitudes face à informação. [...] São, ao mesmo tempo, instrumentais e essenciais, transversais e específicos, procedimentais e conceituais". Não compreendem ações centradas exclusivamente em questões procedimentais para lidar com o universo informacional. Tratam da construção de atitudes afirmativas para que os alunos se interessem e saibam apropriar-se das informações disponíveis nos diversos dispositivos de informação e cultura (PIERUCCINI, PERROTTI, 2012, p. 19).

Dialogismo: Dispositivos dialógicos são de natureza modulável, aberta e flexível, tendo em vista atender necessidades e desejos dos diferentes grupos que aí transitam. Seu desenho final constitui-se no jogo entre produção (especialistas), mediação (instituição mantenedora, corpo técnico-pedagógico) e sujeitos da apropriação (alunos). É, portanto, a negociação permanente 
entre os atores dessa tríade que define e redefine dinamicamente seu formato (PIERUCCINI, 2004).

Ordem informacional dialógica: A articulação entre configuração física, recursos, formas e práticas da biblioteca constitui uma ordem, evidência de que este dispositivo não apenas expressa, mas também define, por meio dos discursos implícitos em sua configuração e pelos modos de relação entre sujeitos e universo simbólico que guarda (PIERUCCINI, PERROTTI, 2012, p.17). 


\section{POLÍTICA PÚBLICA PARA BIBLIOTECAS ESCOLARES: O SABER DE EXPERIÊNCIA}

Foi uma luta enorme. Tudo é uma luta...

Cristina Bisognini

As discussões anteriores apontam para a conjuntura em que se insere a biblioteca escolar em nosso país: com rumos incertos, sua carência na cena educacional denuncia perspectivas que a colocam como elemento acessório ao processo de ensino, revelando desconhecimento quanto a sua atual missão.

O surgimento de texto legislativo determinando a criação de bibliotecas escolares, por si só, não irá transformar realidades, pois "é evidente que a história não se faz com papel. Sozinhos, seja o que for que digam, não mudam nada" (DE CERTEAU, 1995, p.213). Mais que discursos de intenções, é preciso que o poder público empreenda ações, entretanto, implantar bibliotecas escolares não é tarefa revestida de obviedade, pois para que sejam efetivamente relevantes à sociedade, urge sua ressignificação face ao quadro informacional contemporâneo.

Bibliotecas escolares são ambientes complexos e sua implantação extrapola a criação de espaços físicos com recursos informacionais. Nesse sentido, a especificidade da questão precisa ser considerada atentamente, pois está em causa a implantação de um novo dispositivo - novo tanto para políticos, educadores, etc., como para a sociedade em geral -, voltado ao direito de saber informar-se, apropriar-se de informação e cultura e, portanto, essencial à democracia.

Diante disto, o presente capítulo é centrado numa experiência levada a efeito em 1999, na cidade de São Bernardo do Campo (SP), e que teve como fruto a Rede Escolar de Bibliotecas Interativas (REBI), implantada a partir de política pública pautada no paradigma da apropriação cultural. A experiência de pesquisa propiciou o conhecimento de embates, dificuldades, lutas, negociações, articulações e oportunidades que permearam uma ação política diferenciada em torno, não só da implantação de bibliotecas escolares - entendidas como espaços físicos -, mas também voltada para a implantação de um novo conceito num cenário que até então o desconhecia. 
A análise dos relatos, coletados conforme indicado na metodologia deste estudo, foi estruturada em três grandes categorias: Negociações iniciais, Implementação e Permanência da política pública, delineadas a partir de reflexões sobre a teoria e o fato. Para cada uma delas, ainda foram propostas subdivisões, dadas as ramificações que as fases ensejaram.

\subsection{NEGOCIAÇÕES INICIAIS}

A decisão política por implantar a REBI decorreu de uma série de negociações e articulações entre distintos sujeitos que integravam o quadro de profissionais da Secretaria de Educação e Cultura (SEC). Essas relações determinantes do percurso, por vezes, ficam apagadas, na medida em que as atenções tendem a se concentrar nos resultados alcançados. Considerar a força desse momento inicial propiciou desvendar uma teia de elementos, que em conjunto determinaram rumos para as bibliotecas escolares na cidade de São Bernardo do Campo (SBC).

\subsubsection{Compra de Livros: a Clássica Alternativa ao Problema da Leitura}

Na experiência em discussão, a delimitação inicial do problema público, que seria alvo de ação política, se deu quando a nova gestão municipal assumiu o governo e identificou a carência de livros nas escolas públicas de ensino infantil. Atrelando a importância do livro à prática da leitura, a prefeitura respondeu ao problema com uma grande compra de livros para as escolas, decisão que ocorreu em meio a um cenário favorável economicamente.

Quando a [nova gestão assumiu], coincidiu com a aprovação de uma lei do ano anterior que definia os gastos da educação. Além de definir o que poderia se gastar com educação, a lei também definia o que não [se] poderia gastar com educação. Então isso fez com que, por exemplo, um asfalto em frente a uma escola que antes era colocado como gasto da educação não pudesse mais ser colocado. Então o orçamento de repente ficou grande, era o primeiro ano que a gente estava administrando e quando chegou no início do segundo semestre a gente percebeu que precisava investir muito mais do que a gente vinha investindo e existia uma carência grande, na época - a rede era 
só de educação infantil - existia uma carência grande nas escolas de livros infantis e nós fizemos uma grande compra de livros para as escolas (Jumara Bulha ${ }^{22}$ ).

Teve início então a ação oficial que - de acordo com o princípio histórico das políticas para a leitura predominante em nosso país - tinha em vista a distribuição de recursos informacionais ${ }^{23}$.

O problema era esse: a compra de livros para que as escolas tivessem acesso (Dalva Franceschetti ${ }^{24}$ ).

A clássica alternativa ao quadro problemático da leitura no Brasil confirmava a ideia de que o problema estaria exclusivamente ligado à falta de acesso ao livro, razão que justificaria o mero envio de acervo às escolas, inicialmente adotado, como solução política. Esta "solução" é inclusive indicada pela literatura sobre políticas de leitura (OLIVEIRA, 2011) como prática governamental relativamente recente em nosso país, sobretudo em nível subnacional, e indica justamente a carência histórica de ações mais amplas em torno do problema da leitura $^{25}$.

\subsubsection{O Diálogo Redefinindo Percursos}

Festejada por um lado e criticada por outro, a decisão pela compra relegou a segundo plano os desdobramentos práticos da significativa aquisição.

Conforme os diretores [das escolas iam retirar] essas compras eles diziam 'mas eu não tenho onde por!'. Então eram orientados a fazer

\footnotetext{
22 Conforme indicado na Metodologia deste estudo, Jumara Bulha foi Chefe da Divisão de Programas Educacionais da SEC de SBC no momento da implantação da política pública em discussão.

23 Daniela Piergili Weiers de Oliveira, na dissertação Políticas públicas de fomento à leitura: agenda governamental, política nacional e práticas locais, 2011, traz discussão sobre as principais políticas federais de promoção do livro e incentivo à leitura, destacando uma ação concentrada na distribuição de recursos informacionais.

Disponível em:

<http://bibliotecadigital.fgv.br/dspace/bitstream/handle/10438/8248/62090100021.pdf?sequence=1> Acesso em: 26 jun. 2014.

${ }^{24}$ Conforme indicado na Metodologia deste estudo, Dalva Franceschetti inicialmente foi bibliotecária da Seção de Biblioteca Escolar de SBC, posteriormente, tornou-se chefe desta Seção.

${ }^{25} \mathrm{O}$ próprio Estado Brasileiro começou a empreender políticas no âmbito da leitura com certo atraso. O INL surgiu em 1937 orientando a produção e distribuição editorial em um contexto marcado pela emergência dos meios de comunicação de massa, em que a oralidade mediatizada se disseminava numa sociedade em que a cultura letrada ainda não havia se enraizado (BRAGANÇA, 2009).
} 
caixinha [com os livros] nas salas de aula, fazer rodízio, deixar o aluno levar para casa (Jumara Bulha).

Assim, o que fora um momento especial de uma política pública de leitura indispensável e urgente - poderia caracterizar sério problema, em razão de distâncias entre a ação de gabinete e os contextos locais.

As incertezas explicitadas pelos profissionais da educação quanto ao uso dos livros evidenciou para a SEC que a simples distribuição de acervos seria uma política inócua, pois os próprios educadores admitiram a necessidade de espaços, bem como de orientação para o desenvolvimento de ações com os livros adquiridos. Logo, os questionamentos acerca do que fazer, como utilizar e onde colocar o material que estava sendo entregue às escolas possibilitaram que a estrutura administrativa tivesse uma visão mais alargada do problema, percebendo que a compra de livros era apenas parte de uma solução. Conforme argumentado,

A compra de livros desencadeou na escola a necessidade de ter um espaço para os livros (Jumara Bulha).

Para ocupar-se das questões que o fato havia gerado, o poder público determinou a criação de uma Seção de Biblioteca Escolar (SBE). A questão ganhava assim novas dimensões, inserindo-se na agenda política não mais de forma fragmentada, ou seja, apenas como uma necessidade de livros. As manifestações dos profissionais da educação, quanto à organização e uso dos acervos adquiridos em atividades pedagógicas com as crianças, delineavam complexidades até então ignoradas.

Ficou evidente então a importância de que a experiência daqueles diretamente envolvidos com o problema fosse considerada para dimensionar os rumos da política pública. Assim, o diálogo travado com os atores do terreno apresentou-se como elemento essencial neste momento, determinando alterações na solução inicialmente proposta.

Como descreve Deubel (2007), a experiência revelou que a política pública constituiuse, essencialmente, por palavras, já que a partir da retórica os sujeitos argumentaram e persuadiram, demonstrando a necessidade de uma ação diversa. Todavia, a estrutura administrativa aberta ao diálogo foi primordial à redefinição da ação inicial, comprovando a importância de que nunca seja obliterada nem transposta "a alteridade que mantém, diante e fora de nós, as experiências e as observações ancoradas alhures, em outros lugares" (DE CERTEAU, 1995, p.222). 
Por sua vez, embora prescrições teóricas apontem a importância da concorrência da sociedade na delimitação de problemas públicos, isto nem sempre ocorrerá. Na situação em foco, a participação da sociedade reivindicando livros ou bibliotecas não ocorreu, sobretudo pela inexistência ou mau funcionamento destas entre nós. Ou seja, a população não reivindica às esferas decisórias a inclusão da biblioteca escolar na agenda política porque desconhece sua finalidade, assim como sua importância sociocultural e educativa. Para Silva (1999, p.52), essa relação de estranhamento entre grande parte da população e a biblioteca escolar acaba determinando que esta não seja vista como dever do poder público para com a sociedade, deixando assim de ser reivindicada como tal.

Nesse sentido, transformações de qualidade no âmbito das bibliotecas escolares dependem, em grande parte, de quadros internos, vale dizer, gestores, atentos às necessidades latentes, às situações que nem chegam a ser nomeadas e consideradas problemáticas pela população em geral.

\subsubsection{Busca por Modelos}

A Seção de Biblioteca Escolar iniciou suas atividades contando com um quadro de quatro bibliotecárias, incluindo a chefe. A partir de demanda da SEC, as profissionais passaram a se ocupar com a implantação de três bibliotecas escolares:

O secretário tinha falado que queria informatizar três, que fossem piloto, e dessas três disseminar para a rede inteira (Cristina Bisognini $\left.{ }^{26}\right)$.

A ação partiu do planejamento elaborado por Cristina, então chefe da Seção de Biblioteca Escolar:

Que era a partir dos requisitos que eu tinha: informatizar, fazer o processamento do acervo, colocar no sistema, preencher planilha (Cristina Bisognini).

\footnotetext{
${ }^{26}$ Conforme indicado na Metodologia deste estudo a bibliotecária Cristina Bisognini, foi chefe da Seção de Biblioteca Escolar no momento da implantação da política pública em discussão.
} 
A perspectiva que pautava o trabalho da SBE era, então, voltada à organização do acervo adquirido e ia ao encontro do conceito arraigado em nossa sociedade de que a biblioteca escolar é um conjunto de livros organizados. A concepção do próprio quadro profissional diretamente envolvido com a questão - e que é característica de nosso país -, revelava um desconhecimento sobre o potencial da biblioteca escolar e sua função na educação, na medida em que os esforços se concentraram em atividades técnicas voltadas à organização e disponibilização dos livros.

O próprio secretário de Educação e Cultura, ao falar dos rumos posteriormente adotados, afirma que neste momento inicial:

A ideia era colocar uma biblioteca normal em cada unidade escolar (Admir Ferro ${ }^{27}$, grifo nosso).

Revelando, com isso, que as decisões futuramente tomadas no campo das bibliotecas escolares em São Bernardo do Campo fugiam aos modelos por ele conhecidos. Os sujeitos diretamente implicados nas instâncias decisórias da esfera educacional - privilegiados quanto à definição do desenvolvimento de bibliotecas escolares - deram mostras das indefinições quanto à função deste dispositivo, até mesmo para aqueles diretamente envolvidos com a administração da educação. A situação ilustra a complexidade da proposição de ações complexas no campo das bibliotecas escolares, pois o desconhecimento não é característico deste cenário específico, nem se restringe à grande massa populacional, é antes uma marca de nosso país, em que muitos ou não tiveram contato com uma biblioteca ao longo de sua educação ou conheceram organismos voltados à preservação e difusão.

Em meio às atividades voltadas à organização e disponibilização dos livros, havia a preocupação em

Ensinar as professoras como se organizava uma biblioteca de escola (Cristina Bisognini).

Assim, Cristina, que era chefe da Seção de Biblioteca Escolar, começou a

Lecionar para essas professoras ensinando-as como é que se organiza uma biblioteca de escola (Cristina Bisognini).

\footnotetext{
${ }^{27}$ Conforme indicado na Metodologia deste estudo, Admir Donizetti Ferro era secretário de Educação e Cultura de São Bernardo do Campo, no momento da implantação da política pública em discussão.
} 
A intenção primeira foi capacitar os professores das escolas em que seriam implantadas as bibliotecas-piloto, pois seria o quadro de profissionais da própria escola que se responsabilizaria pela manutenção da biblioteca e, consequente, pelo desenvolvimento de atividades junto aos alunos a partir dos recursos disponibilizados. Além disso, objetivava-se que os profissionais das demais escolas também fossem alvo da formação.

\subsubsection{Busca por Parcerias Inter e Transdisciplinares}

No início das atividades voltadas à formação dos professores, para que organizassem e utilizassem os livros adquiridos, Cristina ponderou que

Era muita gente, era bastante trabalho e então pensei "precisamos estruturar isso aqui, pois isso aqui não é para uma pessoa, nós temos, acho que umas vinte escolas, mais as outras, formam quase uma centena. Eu sozinha não vou dar conta”. Já sabia que aquilo seria um trabalho muito grande (Cristina Bisognini).

E, então, considerou

Preciso de ajuda! E a USP é o melhor lugar do mundo para que se possa pedir ajuda. Nós contratamos o pessoal que nos for indicado e então estaremos no rumo certo (Cristina Bisognini).

Após reconhecer que seria indispensável recorrer a outras instâncias, a bibliotecáriachefe entrou em contato com o Departamento de Biblioteconomia e Documentação da Escola de Comunicações e Artes (CBD/ECA/USP), face às referências sobre o trabalho do Prof. Dr. Edmir Perrotti, docente daquele departamento. Conforme afirmou:

Ouvia todo mundo dizendo sobre os cursos do professor Edmir de literatura infantil. Então pensei em pedir ajuda a ele em busca de formação (Cristina Bisognini).

A fala evidencia aspectos que merecem atenção. Ainda que a referência a "todo mundo" não explicite o universo de pessoas ouvidas, o fato é que houve indagações sobre busca de alternativas e soluções, reconhecendo-se que o corpo funcional mostrava-se carente de referências para desenvolver um trabalho à altura dos investimentos realizados. Essa busca inicial expôs, além da relevância de que profissionais estejam aptos a dimensionar problemas, 
a importância de que sejam capazes de reconhecer carências internas e identificar instâncias que possam contribuir com soluções efetivas.

A ação foi ao encontro do exposto na literatura, que indica a política como "resultado de processos institucionais influenciados por atores não-institucionais" (CAHN, 1995, p.207, tradução nossa). Nesse sentido, aqueles que não estão diretamente implicados na administração pública podem contribuir com soluções para determinado problema público, sendo que acadêmicos e pesquisadores formam relevante grupo dentre os chamados atores não-institucionais, pois frequentemente são consultados para a escolha das alternativas ao enfrentamento de problemas públicos: embora estejam "fora do governo, não estão apenas observando este", deixando evidente sua relevância nas decisões políticas (KINGDON, 2003, p.66).

\subsubsection{A Voz do Campo Científico}

A análise da situação, pelos pesquisadores da universidade ${ }^{28}$, deixou evidente que a questão em causa era muito mais complexa que a simples necessidade de distribuir livros às escolas e capacitar pontualmente profissionais para utilizá-los em atividades pedagógicas; complexidade esta que apenas começava a ser desvendada pelos profissionais técnicoadministrativos da prefeitura.

De acordo com os relatos, o contato deu margens a novas alternativas. Ao invés de limitar-se à demanda por formação, ou seja, oferta de cursos, conforme havia sido requisitado, foi lançada a seguinte questão:

Você não acha que seria possível pensar no espaço em que vai ficar o acervo? Pensar em bibliotecas escolares...(Prof. Dr. Edmir Perrotti $^{29}$ ).

\footnotetext{
28 Conforme relatado, a chefe da Seção de Biblioteca Escolar havia entrado em contato com o Prof. Dr. Edmir Perrotti em busca de soluções no sentido de realizar atividades de formação com os professores das escolas municipais, com vistas a otimizar o uso dos livros comprados pela SEC.

${ }^{29}$ Conforme indicado na Metodologia deste estudo, o Prof. Dr. Edmir Perrotti foi o mentor intelectual e assessor da implantação da REBI.
} 
Assim, para além de uma proposta trivial, a objetivação e nomeação do problema implicado na leitura - que, conforme já salientado anteriormente, vai além da oferta de livros às populações -, demandaria o desenvolvimento de uma ação complexa, com a criação de dispositivos de mediação cultural. Conforme Perrotti indica, foi proposta uma rede de bibliotecas escolares, pois para ele estava claro que

Unidades isoladas no mundo de hoje têm todo o tipo de dificuldades, porque não há instituição que consiga dar conta da quantidade de informações geradas no cenário contemporâneo. Precisava ser pensada uma configuração de rede (Prof. Dr. Edmir Perrotti).

A estratégia, para dar concretude e evidenciar a diferença entre a proposta inicial e a resposta da universidade, foi apresentar uma Biblioteca Escolar Interativa (BEI) que havia sido implantada em escola da rede municipal de ensino de São Paulo ${ }^{30}$. Resultado de pesquisas que vinham sendo desenvolvidas, a BEI era fruto de parceria com a Fundação de Amparo à Pesquisa do Estado de São Paulo (FAPESP). Para Perrotti, criar este dispositivo foi ação fundamental

Primeiro para testar novos conceitos e novas concepções, mas, segundo, porque precisávamos mostrar para o país objetivamente, concretamente, algumas coisas, e especialmente os resultados que se conseguia do ponto de vista de aprendizagem, do ensino, enfim, de participação cultural, de abertura de possibilidades de conhecimento, de cultura para os alunos. A importância disto no processo de aprendizagem é uma hipótese que precisávamos provar, mas com algo concreto, e foi daí que fizemos. Tínhamos um problema teórico por trás, ou seja, partíamos da constatação de que biblioteca e Educação ainda não se conheciam e não se reconheciam e isto era e continua sendo um problema educacional importante, especialmente no mundo contemporâneo (Prof. Dr. Edmir Perrotti).

Esta experiência propiciou a elaboração de um dispositivo tangível, importante para que os pesquisadores comunicassem concretamente uma concepção inovadora de biblioteca

\footnotetext{
${ }^{30}$ A BEI em questão havia sido instalada na Escola Municipal de Ensino Fundamental "Prof. Roberto Mange e resultou de um projeto de pesquisa criado pelo Programa Serviços de Informação em Educação (PROESI), do CBD/ECA/USP. Financiado pelo Programa de Melhoria do Ensino Público da FAPESP, o projeto contou com diferentes apoios e parceiros. O objetivo foi desenvolver um novo conceito de biblioteca escolar, capaz de contribuir para a resolução de sérias dificuldades educacionais do país, estimulando relações críticas e criativas com o conhecimento. O trabalho foi realizado por equipes de professores, alunos de graduação e pós-graduação da ECA e da Faculdade de Arquitetura e Urbanismo (FAU) da USP, de educadores da EMEF Prof. Roberto Mange e com a cooperação de pesquisadores franceses reunidos pelo CRDP - Académie de Créteil (Fonte: Informativo de divulgação do projeto. Disponível no acervo do CRB8).
} 
escolar. Neste sentido, apoiar-se nos resultados concretos e objetivos de pesquisas foi fundamental à proposta de um curso de ação diferenciado. Por sua vez, a experiência desenvolvida em parceria com a FAPESP evidenciou para os pesquisadores a importância de que o estado assumisse, efetivamente, projetos como aquele, já que uma gestão política favorável, além da capacidade de propulsionar mudanças, é essencial para que ações se consolidem no terreno ${ }^{31}$.

Ademais, se por um lado, a equipe de pesquisadores já havia implantado e testado o conceito de BEI numa unidade isolada, de outro, estava em pauta não a simples reprodução, em escola de São Bernardo do Campo, daquilo já haviam feito, pois conforme Perrotti assinala,

Era uma questão que não era só fazer um espaço, repetir um como estava lá, mas era todo um trabalho, primeiro da própria equipe da Secretaria, que precisava se apropriar do novo conceito, portanto das novas práticas que esse novo conceito envolvia. De outro lado, as questões operacionais, quer dizer, você fazer a gestão de equipamentos que você ainda não tem o domínio é complicado (Prof. Dr. Edmir Perrotti).

A fala dá mostras da importância do reconhecimento da complexidade da questão biblioteca escolar. Se por um lado, o contexto social do terreno é marcado por situações para as quais são exigidas soluções imediatas, por outro, é certo que nem sempre estas são as mais adequadas para resolver, de fato, os problemas em causa. Muitas vezes, tais soluções tendem apenas a mitigar problemas, ou então se limitam a reproduzir ações empreendidas em outros contextos sociais. A mera transposição de soluções de um cenário a outro se mostra incompatível e insuficiente para o enfrentamento de problemas públicos, na medida em que deixa de considerar as especificidades que marcam cada realidade e, portanto, interferem nos percursos e resultados.

\footnotetext{
${ }^{31}$ Embora seja preciso aceitar o estado como aparato de dominação, há que se considerar que é também um campo de disputas no qual "a correlação de forças, a movimentação social e a organização política dos interesses têm papel decisivo". Nesse sentido, tratá-lo como algo neutro é tão insuficiente quanto tratá-lo como a encarnação do mal, mero "comitê de negócios' destinado a oprimir as massas". O Estado continua a ser elemento-chave na vida concreta dos povos do mundo, por mais debilitado que esteja. Por tudo isso, "o Estado precisa ser assimilado tanto como estrutura de dominação quanto como parâmetro ético de convivência e locus para o encontro de soluções positivas para os problemas sociais” (NOGUEIRA, 2004, p. 61).
} 
Por outro lado, o fato de o campo científico dispor de resultados de pesquisa aplicáveis de forma imediata ajudou muito para que a chefe da SBE vislumbrasse o potencial da proposta. Com isso, ela teve elementos concretos para encaminhar às instâncias superiores responsáveis por decidirem pela continuidade das interlocuções - para que a alternativa fosse adotada pelo poder público.

O diálogo entre terreno e universidade para propor novas referências ao enfrentamento de problemas sociais, foi fundamental neste momento. Ficou evidente o papel crucial do diagnóstico e da crítica a uma situação vigente, como também a importância de um olhar externo na implantação de ações políticas que necessariamente mexem com estruturas sociais fortemente ancoradas em princípios contrários.

\subsubsection{O Protagonismo dos Profissionais}

A chefe da SBE foi protagonista das ações iniciais que culminaram na implantação da REBI. Conforme relatou, após conhecer a BEI da EMEF Roberto Mange, percebeu que

Tinha encontrado o ouro. A mina de ouro! Naquele momento a gente sabia que iria mudar a história da biblioteca. [...] Eu a vida inteira tinha sonhado com isso, imaginado que existia uma biblioteca que pudesse realmente mudar a vida de uma criança... quando ele [o Prof. Edmir Perrotti] contou, eu já pensei: mudaremos tudo! (Cristina Bisognini).

Todavia, as possibilidades de realização do sonho da biblioteca escolar implicavam ferramentas. Por esta razão, quando Cristina ouviu

As palavras do professor Edmir dizendo que eles tinham o pacote completo, que não só tinham a formação, mas sim "isso e tudo mais" [...], tinham uma estrutura grande de acompanhamento desse trabalho das bibliotecas nas escolas,

desejo e razão ganharam forças para redefinir rumos face ao problema da biblioteca escolar. A protagonista dimensionou que não estava sendo proposta somente a criação de espaços físicos, mas sim de uma rede de bibliotecas articuladas, a ser desenvolvida a partir de um conjunto de ações em parceria com um quadro multidisciplinar habilitado, com ampla experiência na área. 
Nesse sentido, acreditou que

Se a prefeitura topasse, isso iria dar uma reviravolta gigantesca na história das bibliotecas escolares (Cristina Bisognini).

Assim, reportou-se às instâncias superiores, revelando um novo e importante momento do diálogo: a busca de parcerias, dentro da própria SEC. O que até então era entusiasmo e interesse da bibliotecária-chefe precisava ser expandido para outros sujeitos implicados na administração municipal, igualmente importantes para a constituição de uma força interna, indispensável à reverberação do novo.

Quando eu cheguei com a notícia para minha chefe imediata, expliquei tudo e ela já marcou um horário com a diretora do Departamento de Ações Educacionais. Em seguida nós três já vimos que precisávamos voltar para a USP e conversar com o professor Edmir. Marcamos um horário e voltamos (Cristina Bisognini).

O novo contato acabou por confirmar o interesse na alternativa oferecida pelo docente. Assim, a implantação de uma rede de bibliotecas escolares interativas, sob a assessoria de equipe coordenada pelo Prof. Dr. Edmir Perrotti, seria a alternativa apresentada à gestão municipal, para o problema inicialmente delimitado como a mera carência de livros nas escolas. A questão ganhava densidade, em razão das inúmeras negociações que precederam a entrada dos decisores políticos nas discussões entre estado e universidade.

A experiência em causa trouxe luz ao papel dos profissionais diretamente implicados neste momento, de definição de rotas para solucionar problemas públicos. A bibliotecária demonstrou clareza sobre as dificuldades apresentadas e buscou apoio em outras instâncias, não se limitando ao simples cumprimento burocrático de uma rotina e de horas de trabalho. $\mathrm{O}$ comprometimento crítico e criativo com a resolução do problema mostrou-se determinante à busca por soluções objetivas, muito mais amplas e significativas, em consonância com as dimensões dos contextos e situações adversas em causa.

Nesse sentido, foi demonstrada a importância da disposição (ética, existencial, intelectual) em sair de si e pensar o outro, já que a reconfiguração de cenários insatisfatórios compreende sujeitos, fundamentais para a produção da história ao invés da reprodução de uma ordem fechada sobre si mesma (NOGUEIRA, 2004, p.62; TOURAINE, 1996). Assim, a ação técnico-especializada, quando alimentada por visão que compreenda todo o potencial da 
política - como política dos cidadãos -, terá provavelmente chances de reverter quadros que as decisões legislativas, em geral, não conseguem alcançar.

\subsubsection{Vontade Política}

A partir do processo anterior - constituído por meio de reflexões, articulações, proposições e perspectivas avaliadas no âmbito dos quadros da SEC -, em 1999 foi criado o Programa Rede Escolar de Bibliotecas Interativas de São Bernardo do Campo, resultado do convênio de cooperação técnico-acadêmica estabelecido entre a prefeitura de São Bernardo do Campo e a ECA/USP, tendo em vista viabilizar a implantação e apropriação de uma rede de bibliotecas escolares interativas.

Se, por um lado, a situação ressaltou a importância da postura dos sujeitos que empregaram esforços para a superação de um quadro social adverso, de outro, é preciso salientar a disponibilidade do prefeito em querer conhecer a alternativa sugerida, avalizada pelo secretário de Educação e Cultura, assim como o reconhecimento do valor educativo e cultural das bibliotecas, pois, para ele, a escolha se deu para que

O universo da cidade se beneficiasse das bibliotecas a serem criadas, principalmente as crianças e os adolescentes, mas, também a comunidade adulta (Maurício Soares ${ }^{32}$ ).

Apesar do problemático contexto brasileiro, quando propostas reúnem resolução de problemas sociais e visibilidade política, evidentemente conseguem ter maior impacto sobre as decisões dos gestores. Houve, entretanto, quem afirmasse que a opção por implantar a REBI, num primeiro momento, ocorreu devido à

Visibilidade que isso daria politicamente, um espaço bonito e bem organizado (Dalva Franceschetti).

De fato, se é certo o empreendimento de ações tendo em vista obter resultados tangíveis, que gerem dividendos políticos no curto prazo de cada mandato, é primordial

\footnotetext{
${ }^{32}$ Conforme indicado na Metodologia deste estudo, Maurício Soares foi o prefeito responsável pela implantação da REBI.
} 
destacar, porém, que a decisão da gestão municipal, optando por desenvolver a rede de bibliotecas escolares, foi surpreendente. Sobre a escolha política, nos foi afirmado que

Isso realmente foi inédito. [...]. O secretário [de Educação e Cultura] levou a proposta para o prefeito e, de imediato, o prefeito topou. Então esse foi um processo muito rápido de um envolvimento político numa ação de biblioteca (Dalva Franceschetti).

Uma gestão pública que saiba compreender a importância de bibliotecas escolares, vislumbrando seu potencial transformador para o cenário da educação pública municipal, face aos novos cenários informacionais no país, é questão que deve ser cuidadosamente considerada em qualquer iniciativa nessa área. O poder público, vale dizer, mostrou ter visão crítica da questão. Compreendeu que seriam precisas ações complexas, que não se resumiam a soluções imediatistas e pontuais.

Nessa conjuntura, a chefe da Seção de Biblioteca Escolar expôs que o secretário de Educação e Cultura

Merece todo o nosso agradecimento porque ele foi realmente a pessoa que viu, porque antes de a gente chegar na USP, ele que já tinha falado que queria informatizar três bibliotecas que fossem piloto. Ele já queria informatizar e que fizesse empréstimo ${ }^{33}$ (Cristina Bisognini).

Além da vontade de empreender ações no âmbito das bibliotecas, acolheu novas propostas

Ele [o secretário de Educação e Cultura] percebeu que o que ele tinha pedido para nós fazermos, que era informatizar essas três bibliotecas, podia ser muito maior ou muito melhor, muito mais bem acompanhado (Cristina Bisognini).

O desejo político por lançar iniciativas neste âmbito foi ao encontro da disposição em acolher alternativas geradas por instâncias especialistas, externas à prefeitura. A parceria com a universidade comprovava que a prefeitura admitia a relevância de uma ação inovadora que favorecesse o contexto da educação municipal.

\footnotetext{
${ }^{33}$ Nesse ponto vale destacar que a entrevistada não é mais funcionária da prefeitura de SBC, e também não desempenha atividade profissional relacionada aos políticos que decidiram pela implantação da REBI. O depoimento, portanto, não se aproxima de possíveis representações que tenham em vista 'favorecer' a imagem do político.
} 


\subsection{IMPLEMENTAÇÃo}

A opção pelo desenvolvimento da Rede Escolar de Bibliotecas Interativas deu início à implementação da política pública de bibliotecas escolares no município, a partir daí contemplando definições acerca de procedimentos, recursos humanos e materiais para sua concretização.

As decisões desta fase foram determinantes para os resultados alcançados, demandando articulações e negociações entre os diferentes sujeitos implicados, direta e indiretamente, na ação política. A experiência lançou luz sobre uma trama de elementos vinculados, revelando que resultados bem sucedidos derivam de ações integradas e negociações entre os sujeitos, empenhados em ressignificar o papel da biblioteca na escola.

\subsubsection{Os Protocolos Explícitos e Implícitos}

A implantação da REBI se deu a partir de uma ação conjunta

[...] da universidade com a Secretaria de Educação, da universidade com o terreno, que visava romper aquela questão histórica da distância entre biblioteca e educação na sociedade no Brasil (Prof. Dr. Edmir Perrotti).

Para tanto, foi firmado um convênio de cooperação técnico-acadêmica, que representou o interesse manifesto da prefeitura em aderir e levar adiante o projeto proposto pela equipe da USP. O diálogo entre as partes deu margens à ação com perspectiva inovadora, com o rompimento da fragmentação dos saberes e convergência destes em prol da resolução efetiva de um problema social.

Nesse sentido, foi fundamental o estabelecimento de um documento oficial, fixando protocolos normativos indispensáveis para assegurar compromissos, deveres, competências e direitos de ambas as partes, pois

[...] o encontro [entre os campos] promove colaborações, e isso é fundamental, mas, também promove tensões e, portanto, disputas (Prof. Dr. Edmir Perrotti). 
Nessa perspectiva, para que houvesse avanços foi importante a regulamentação da relação entre as partes, já que "a toda vontade construtiva são necessários sinais de reconhecimento e acordos tácitos acerca das condições de possibilidade para que lhe seja aberto um espaço onde se desenvolva" (DE CERTEAU, 1995, p.34).

O documento era, assim, indicativo da seriedade do caráter da ação proposta, regulador das possíveis e inevitáveis tensões decorrentes das dinâmicas específicas de cada instância parceira, a partir da declaração das incumbências de ambas as partes na implantação da política pública.

O relato de Cláudia Sarro, Professora de Apoio à Biblioteca Escolar $(\mathrm{PABE})^{34}$, que formou a equipe inicial da implantação da REBI, evidencia a importância conferida ao convênio firmado com a equipe de pesquisadores coordenada pelo Prof. Perrotti,

Acho que esse vínculo entre universidade e poder público foi a questão mais importante para que o projeto pudesse ser assumido, digamos assim, de uma maneira mais consequente e é claro que a administração acabou 'comprando' o projeto, quer dizer, acabou de alguma maneira entendendo a importância do projeto (Cláudia Sarro).

O prefeito também explicitou a relevância da parceria para os rumos da ação política ao declarar que

Esse vínculo foi facilitado pelo professor [Edmir] porque ele é autor da ideia, ele criou o sistema, ele tinha realmente o desejo de fazer isso andar pelo país todo. Então ele abriu um caminho para nós chegarmos na direção da universidade e pleitear um convênio. Eles ajudaram muito, ajudaram de todas as formas, com muita boa vontade, com profissionais muito competentes, e nós, da nossa parte também, fizemos todo o possível [...] E foi um esforço conjunto, de boa vontade de ambas as partes (Maurício Soares).

A propalada "vontade política", ingrediente indispensável ao desenvolvimento de políticas públicas em qualquer âmbito social, teve, nesse caso, amparo no modo como a questão foi apropriada pelos gestores públicos. A articulação da Secretaria com o campo científico se deu a partir da crença na qualidade e viabilidade do projeto, bem como da

\footnotetext{
${ }^{34}$ Esta função será discutida na seção Quadro profissional: identidade na diferença, mais adiante neste estudo.
} 
constatação da necessidade de transformações de uma situação que, embora assumidamente problemática, não se revelava em toda sua complexidade à gestão municipal.

Assim, a resolução do problema público, a partir de critérios e rumos definidos em parceria, foi o objetivo comum a ser alcançado. Nesse sentido, a existência de documento formal, garantindo responsabilidades dos diferentes campos, mostrou-se fundamental ao esforço conjunto, construído por meio do diálogo e da negociação entre perspectivas, por princípio, distintas. Admitiu-se, portanto, que sem a concorrência de ambas as partes o projeto se tornaria inexequível à abordagem pretendida.

Os protocolos formais juntaram-se aos protocolos não-formais, construídos ao longo do processo e implícitos nas relações entre os sujeitos de ambas as instâncias. A atuação conjunta foi sendo desenvolvida e reconhecida ao longo da ação, a partir de inter-relações entre aqueles diretamente envolvidos com o projeto.

\subsubsection{Resultados Concretos e Inovadores: a Rede Escolar de Bibliotecas Interativas}

A política pública previa a implantação de bibliotecas escolares interativas, articuladas em rede. De acordo com Perrotti, objetivava-se a construção de dispositivos em que as crianças fossem

Protagonistas, que participam e que, portanto, constroem juntos esse dispositivo. Que atuassem nele, constituíssem-no e fossem constituídos por ele. Então essa ideia de apropriação cultural é a ideia que pautou esta biblioteca e esta rede (Prof. Dr. Edmir Perrotti).

Educar para a informação, para que os alunos pudessem buscar, selecionar, confrontar, organizar e analisar a infinidade de informações que permeia a vida no mundo contemporâneo era objetivo das Bibliotecas Escolares Interativas (BEIs), desenvolvidas tendo em vista a participação afirmativa e criativa dos alunos nos processos de construção do conhecimento. Nesse sentido, a rede implicou mais que simples conexões técnicas, estava em pauta uma atuação profissional cooperativa e compartilhada, que contemplaria diferentes funções de comunicação, orientação, apoio técnico, formação e troca de experiências. 
As concepções propostas foram materializadas, e o conceito de biblioteca escolar saiu do texto para fazer parte do contexto da educação. A ação política, de fato, reconheceu a necessidade do desenvolvimento de dispositivos diferenciados, assumindo que a simples adequação de espaços - tal qual a colocação de algumas mesas e estantes numa sala disponível - seria insuficiente para que os resultados almejados fossem alcançados em sua plenitude.

A importância da objetivação do novo foi evidenciada na fala dos políticos, que se depararam com a surpresa da população face às bibliotecas criadas. Conforme o prefeito relatou,

Somente abríamos as bibliotecas depois da inauguração, durante a obra ninguém via nada, colocávamos um tapume no local destinado enquanto trabalhavam na construção. As pessoas sabiam que era biblioteca, mas ninguém sabia a concepção, aí quando abria era realmente uma festa (Maurício Soares).

Não só alunos e professores demonstraram admiração pelas bibliotecas criadas, mas, os pais das crianças também reconheceram um organismo diferenciado na cena escolar. De acordo com o secretário de Educação e Cultura,

A população gostou tanto que algumas escolas particulares, por exemplo, a Pueri Domos de São Bernardo, ela implantou a biblioteca igualzinha a nossa, vieram atrás, mas não foram só eles, outros fizeram biblioteca igual a nossa. Uma vez numa das nossas escolas na verdade não era só biblioteca, tínhamos um conjunto ali na escola, laboratório de informática, as escolas são muito bem cuidadas -, um pai veio visitar uma escola e depois perguntou para a funcionária quanto era a mensalidade, porque achou muito boa, achou que era particular, mas não era, era municipal (Admir Ferro).

A construção de espaços físicos foi assumida como importante dimensão da política pública, na medida em que contribuía para comunicar à população a concepção de biblioteca escolar em causa. As falas, carregadas de surpresa e contentamento, permitem entrever que a materialização do conceito inovador foi elemento significativo, contribuindo para que a ação política fosse reconhecida, aprovada e desejada pela comunidade escolar. Sobretudo por se tratar de objeto não configurado como valor para a população em geral, a materialização do conceito mostrou-se fundamental. 
A biblioteca escolar conseguiu se destacar em razão de sua configuração e de suas relações com a comunidade escolar; era a visualização de um estado de mudança.

\subsubsection{Arquitetura, mobiliário e equipamentos}

Mais que um espaço construído, circunscrito, portanto, à condição material, a BEI constituía um ambiente, incorporava também a dimensão simbólica que norteava o projeto. A concepção arquitetônica das bibliotecas era de construção de um ambiente propício ao desenvolvimento das relações do sujeito com educação, informação e cultura, numa perspectiva que priorizava a interação criativa e participativa com a biblioteca (TARALLI, 2007, p.6-7).

Foi planejada para ser ambiente de múltiplos usos, assim, flexibilidade de arranjos espaciais, possibilidades de montagem e desmontagem, permitiam a organização de diferentes cenários para acolher atividades diversas. Todos os elementos presentes na configuração da BEI tinham uma intenção, constituíam o conceito de biblioteca interativa. Logo, a cor do piso, seu material e paginação, eram importantes para o acolhimento e também davam pistas sobre a organização da biblioteca. No espaço infantil foram utilizadas cores próprias, assim como no juvenil; além de espaços destinados ao estudo em grupo e para assistir a filmes e encenações teatrais.

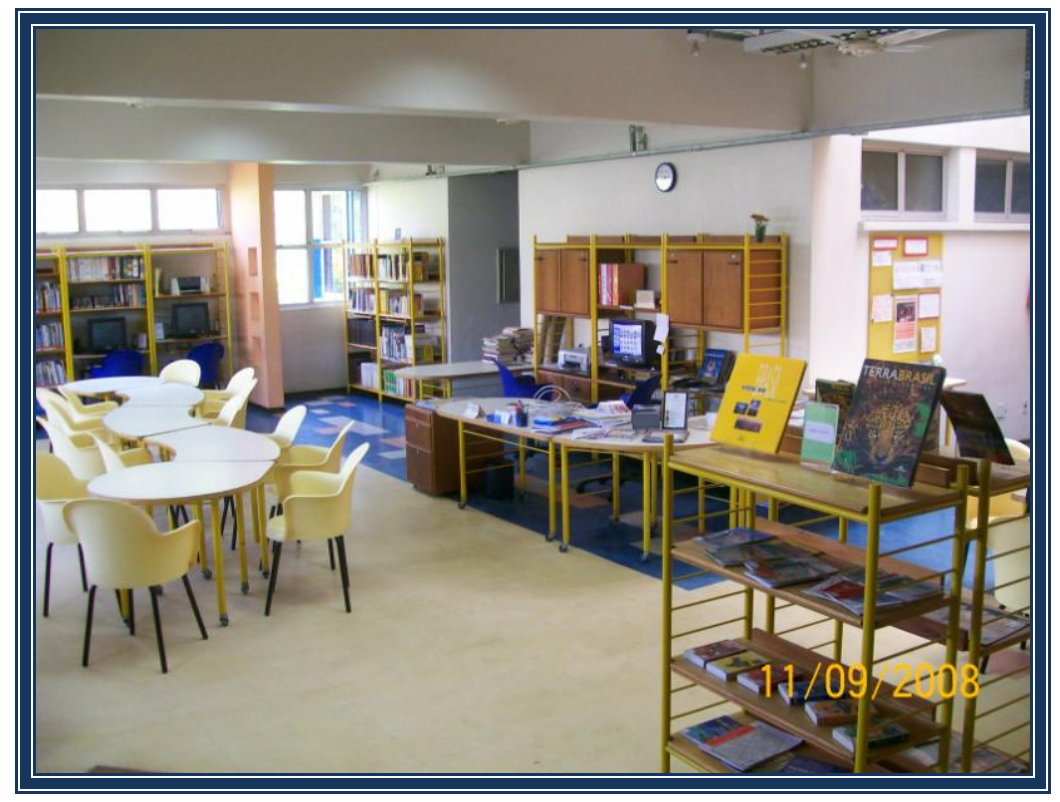

Fotografia 1: BEI Gente Feliz. Escola Erminia Paggi. (Fonte: Acervo da Escola Erminia Paggi) 
Como dispositivo de apropriação cultural, a biblioteca interagia com o espaço externo

As crianças passavam, quem estava fora queria entrar, quem estava dentro às vezes parava um pouco para ver o movimento de fora. Então a comunicação na biblioteca ela sempre foi prioridade, essa comunicação com o externo (Cristina Bisognini).

Quanto aos equipamentos, a BEI dispunha de computadores, televisão, aparelho de som e vídeo, que garantiam o contato dos alunos com informações apresentadas de maneiras variadas. Já o mobiliário, alinhava-se às necessidades de arranjos do ambiente para as diferentes atividades e programações da biblioteca, considerando a faixa etária dos alunos. Assim, as estantes permitiam dispor os materiais ao alcance das mãos das crianças; mesas com cadeiras para estudo em grupo e pufes convidavam à prazerosa imersão na leitura e ao diálogo entre os pares; a arquibancada, para estar confortavelmente interagindo com os colegas, assistir a um filme, uma encenação ou, então, ler um livro, introduziu novo elemento: o espaço da oralidade, categoria fundamental da construção do conhecimento.

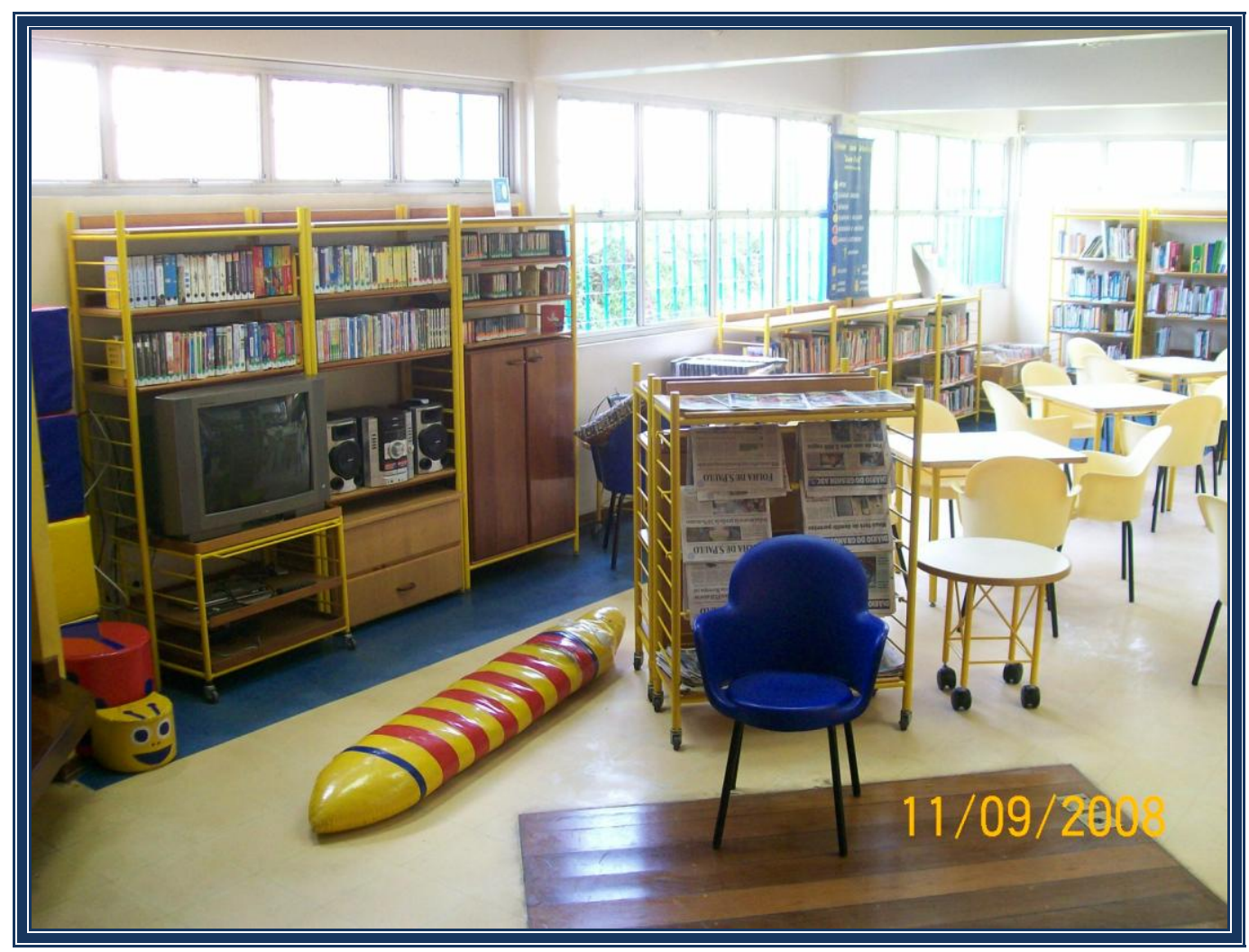

Fotografia 2: BEI Gente Feliz. Escola Erminia Paggi. (Fonte: Acervo da Escola Erminia Paggi)

Além do atendimento a requisitos de ergonomia, alguns dos móveis possuíam dimensão simbólica. Exemplo disso eram as cadeiras, "mais que objetos para sentar adequada 
e confortavelmente. Remetem ao imaginário do abraço, do colo, sensações agradáveis e convidativas à leitura" (TARALLI, 2007, p.30).

Com isso, a comunidade escolar passava a contar com um ambiente acolhedor, que se mostrava propício a usos variados, extrapolando as concepções de biblioteca escolar como espaço para a leitura individual e silenciosa. Conforme relato,

A escola sempre usou bastante a biblioteca para apresentações $e$ eventos, porque era um local grande, tinha arquibancada de madeira, propício para muitas pessoas. Havia cadeiras super confortáveis, então era um local que todo mundo gostava de estar. Quando ia acontecer algum evento que eles achavam que ia caber na biblioteca, era lá que eles procuravam (Cristina Bisognini).

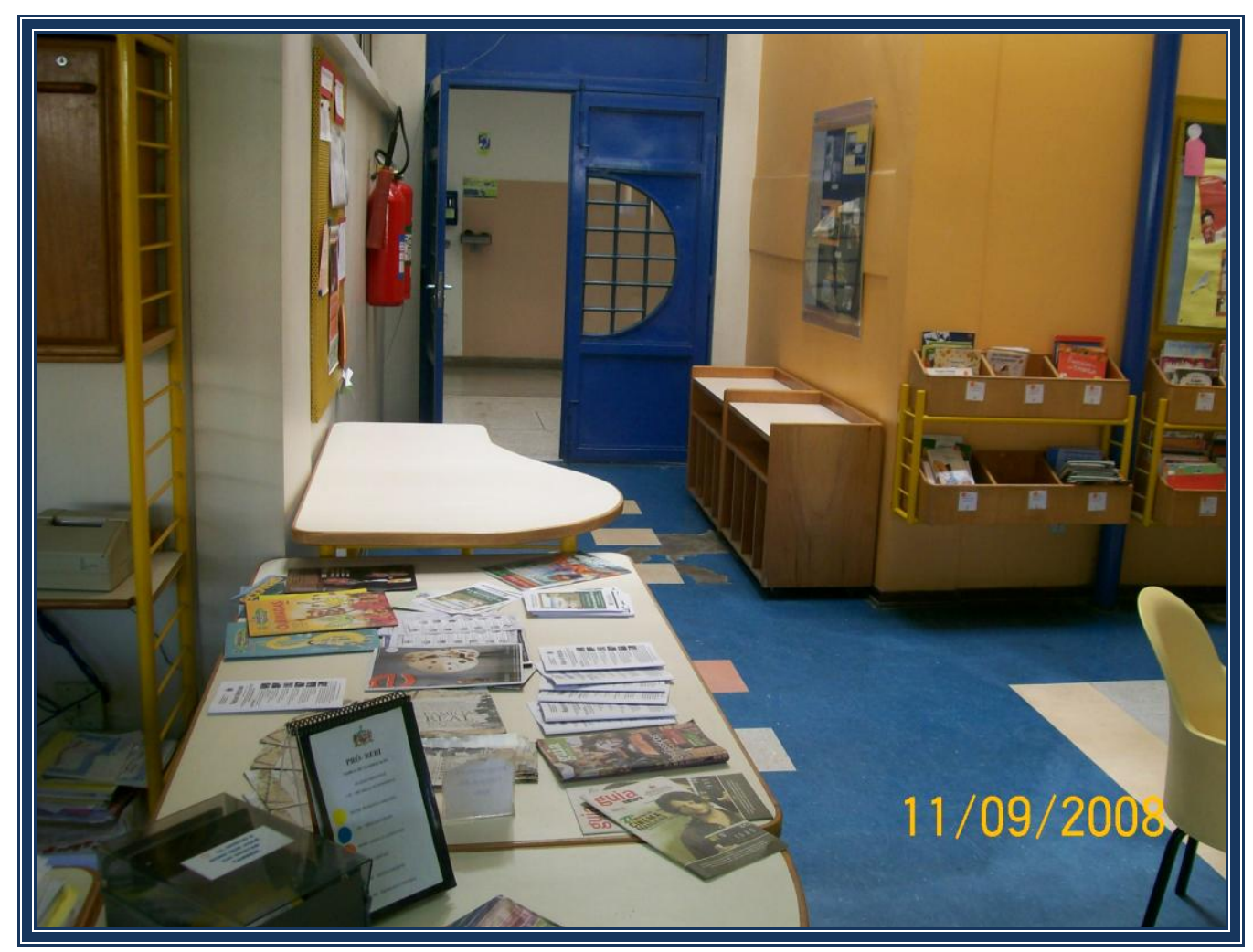

Fotografia 3: BEI Gente Feliz. Escola Erminia Paggi. (Fonte: Acervo da Escola Erminia Paggi) 


\subsubsection{Repertório informacional e linguagem documentária}

O acervo da BEI constituía-se de materiais diversos como livros de ficção e nãoficção, jornais e revistas, histórias em quadrinhos, vídeos de ficção e documentários, CDs musicais, áudio livros, fantoches, globos terrestres. Tais acervos também tiveram papel preponderante no reconhecimento pela comunidade escolar de que as bibliotecas da REBI constituíam uma proposta diferenciada.

As atividades de desenvolvimento de acervo eram permanentes:

\section{Havia renovação do acervo todo ano (Cláudia Sarro).}

A qualidade dos materiais adquiridos pelas escolas também era uma preocupação constante, assim, a Seção de Biblioteca Escolar elaborava listas com sugestões de obras, pois reconhecia que

Às vezes com cem reais você consegue comprar três livros, ou então cinquenta livros de dois reais, que estão até escritos com grafia errada. A gente não queria os cinquenta livros de dois reais, queríamos os três maravilhosos! E esses três iam produzir muita alegria e informação, desencadeando um processo nas crianças que os de dois reais não iriam desencadear nunca... É o encantamento pela leitura e a ampliação do imaginário (Cristina Bisognini).

O reconhecimento de que a seleção dos recursos informacionais era uma categoria fundamental à qualidade do produto oferecido à população, incluiu na estrutura administrativa da REBI uma profissional especializada, para desempenhar funções de seleção de livros e outros recursos para as bibliotecas escolares.

Tinha uma pessoa que ficava só conhecendo novos livros, lendo para incluir, para ver se era realmente adequado. Então tinha DVD, vídeo, livro e mais algumas coisas alternativas dentro desta lista. Não eram apenas livros, por exemplo, que CDs de música a gente sugeriria para uma criança, o que seria legal ter, quais filmes....A escola podia escolher a partir dessa lista e se quisesse algo que não estivesse lá, poderia sugerir (Cristina Bisognini).

O projeto previu, com isso, a importância do planejamento para a constituição de acervos ricos qualitativamente, incorporando a necessidade de 
Um trabalho criterioso com uma equipe qualificada que pudesse fazer essa seleção, a gente precisava conhecer o mercado editorial e ao mesmo tempo ter critérios para fazer essa seleção (Cláudia Sarro).

Revelou-se assim a importância de instâncias específicas para a constituição do acervo das bibliotecas escolares, assim como a importância do diálogo com os profissionais da educação, que podiam sugerir materiais que julgassem pertinentes para as BEIs.

Aliada à riqueza do acervo, estava a possibilidade de interação direta do aluno com os recursos informacionais. No ambiente sem barreiras físicas entre o sujeito e a informação estava em causa não somente o livre acesso às informações, mas, sobretudo, a formação para a autonomia no uso da biblioteca.

Os materiais, classificados de acordo com o Sistema de Classificação Decimal de Dewey (CDD), recebiam codificação adicional por cores, um elemento passível de apreensão por públicos leigos ou ainda não iniciados no universo da informação organizada. Além disso, o ambiente dispunha de sinalizações e manuais de orientação, com o intuito de favorecer a comunicação entre a biblioteca e a comunidade escolar.

Os recursos informacionais eram organizados em setores específicos: 1) Obras de referência; 2) Primeiras leituras: com estantes-caixas que reuniam livros de ficção infantil com pouco texto ou somente com imagens e que ficavam ao alcance das crianças menores; 3 ) Som e imagem: com Cds e DVDs; 4) Jornais e revistas; 5) e, por fim, Coleções: organizada de acordo com um tema específico o qual o profissional da biblioteca desejasse evidenciar (PIERUCCINI, 2007). Assim, o acervo era imediatamente reconhecido e acessível a quaisquer públicos, constituindo uma biblioteca que fazia sentido para as crianças e jovens, permitindo que se relacionassem autonomamente com aquele universo informacional.

Em sintonia com a perspectiva da apropriação cultural, o conceito de organização de acervo buscou aproximações com os públicos a serem atendidos, para que se sentissem acolhidos na biblioteca, a partir das linguagens, dos códigos e sistemas de ordenação da informação. A preocupação do projeto com o acolhimento dos sujeitos, por meio das configurações propostas, favoreceu a adesão e vínculos da comunidade escolar, elemento fundamental à expansão da REBI. 


\subsubsection{Práticas de gestão, pedagógicas e culturais}

As práticas de gestão, pedagógicas e culturais, também foram objeto de ação. Estava claro que o uso da biblioteca não poderia ser fortuito, mantendo-se a velha noção de instância de apoio à sala de aula, nem tampouco que fosse delegada à comunidade escolar a construção dos vínculos indispensáveis para que se apropriassem do dispositivo.

Com base nessa premissa, foi determinado um horário específico para que cada turma de alunos fosse à biblioteca, ao menos uma vez por semana, acompanhada pelo professor responsável. Com isso, objetivava-se garantir formalmente a integração da BEI às práticas pedagógicas da escola.

Neste momento, a Professora de Apoio a Biblioteca Escolar desenvolvia ações específicas com os estudantes, planejadas previamente e articuladas aos conteúdos aprendidos em sala de aula. As práticas eram variadas, incluindo pesquisa escolar; atividades desenvolvidas com jornal - valorizado como importante instrumento de comunicação e participação na cultura; roda de histórias, para facilitar e estimular a expressão cultural dos alunos; práticas que introduziam o uso do vídeo; práticas em torno da construção da memória do grupo/comunidade (PERROTTI, 2007). A proposta incluía a participação do professor nas atividades da biblioteca, acompanhando o trabalho desenvolvido pela PABE. O objetivo das atividades com os alunos era a aprendizagem de processos de busca, seleção, organização e análise de informações, o estímulo à leitura, a provocação da curiosidade e da imaginação.

As práticas no âmbito da biblioteca escolar implicaram a decisão por incluir uma profissional nos quadros da escola, capacitada a desenvolver atividades juntos aos alunos, elemento que veremos mais adiante neste estudo. Com isso, a política pública contemplou o redimensionamento de estruturas administrativas internas, tendo em vista conceder uma profissional exclusiva para a BEI.

Os estudantes também podiam utilizar a biblioteca no contraturno. Fora isso, um dia por semana a biblioteca deveria abrir especialmente para a comunidade em geral, possibilitando que qualquer pessoa, independentemente de vínculos formais com a escola, pudesse dela usufruir. 
A biblioteca escolar ia além da articulação com as atividades educativas. A possibilidade de que os alunos utilizassem a BEI em suas horas livres, o estímulo ao ócio criativo, à aquisição de "uma gama de interesses inteligentes" não relacionados às obrigações cotidianas (RUSSEL, 2002), visava um leitor em diálogo com a biblioteca escolar, a partir de interesses e desejo próprios, dimensão fundamental à aprendizagem e apropriação cultural.

As diversas ações empreendidas vão ao encontro da afirmação de uma entrevistada, que afirmou estar em causa uma biblioteca que

Não era só um espaço bonito. Assim, embora a primeira coisa seria o impacto que daria o espaço, a gente batalhou muito para que aquilo realmente fizesse diferença na aprendizagem (Dalva Franceschetti).

Nesse sentido, mesmo antes da inauguração das bibliotecas, havia a preocupação com o estabelecimento de vínculos entre os alunos e a BEI. Assim, as crianças

Escolhiam inclusive o nome da biblioteca. Era uma eleição interna (Cristina Bisognini).

A SBE compreendia a relevância de estimular o sentimento de pertencimento dos estudantes em relação à biblioteca, ainda em vias de inauguração. Para tanto, promoveu ações para que os alunos participassem das definições quanto à organização do acervo; uma forma também para que já entrassem em contato com os modos de organização do dispositivo. Conforme relato de uma PABE,

Eu comecei a organizar com as crianças o acervo, como ele seria organizado depois, por cores, a gene levou os livros para a sala e fizemos uma planilha pelas áreas de conhecimento. Como que era livro de ficção e de não ficção. Ai trabalhei com eles a questão das cores, junto com as professoras eles foram fazendo uma espécie de trabalho de catalogação, à medida que iam conhecendo os livros (Cláudia Sarro).

O depoimento revela que a política foi além da criação de espaços físicos, contemplando o desenvolvimento de ações voltadas aos alunos e professores, e demonstra que, para o quadro gestor, era certo o valor da biblioteca na educação. Nesse sentido, a política comportou procedimentos para garantir a integração da biblioteca ao ensino e, também, a necessidade de um profissional específico para atuar neste dispositivo. 


\subsubsection{Comunicação de Intenções e Resultados}

O planejamento inicial previa a criação de cinco bibliotecas escolares interativas no município: uma delas numa escola de educação infantil, outra em escola de educação especial e mais 3 no ensino fundamental.

Uma sexta escola de ensino fundamental foi agregada ao plano inicial por solicitação explícita de sua diretora. Convidada a conhecer a BEI da EMEF Roberto Mange ${ }^{35}$, a diretora concluiu que estava "fazendo tudo errado" no espaço planejado para abrigar uma biblioteca, e que as obras em execução em sua escola estavam em rota de colisão com o que acabara de conhecer ali. Assim, vislumbrando a possibilidade de que a escola passasse a dispor de dispositivo diferenciado daquilo que, até então, ela própria compreendia como biblioteca escolar, pressionou a SEC para que sua escola fosse incluída no plano inicial. O esforço empreendido trouxe resultados e, com isso, a proposta foi redimensionada para contemplar a criação de seis bibliotecas escolares interativas.

A alteração no percurso inicial, por um lado, revelou o protagonismo da diretora, que se lançou em negociações com instâncias hierárquicas abertas ao diálogo, indicando que a política dos políticos - determinada exclusivamente dentro de gabinetes distanciados do campo social -, mostra-se incompatível com a resolução de problemas que afetam o meio social $^{36}$. Por outro lado, a experiência trouxe luz à estratégia adotada pela gestão da SBE, que se ocupou com a comunicação da intenção em causa e, posteriormente, dos resultados.

Um dos primeiros passos da SBE foi organizar diversas visitas para que os profissionais da rede de ensino conhecessem a BEI da EMEF Roberto Mange. A ação estratégica comunicava - aos professores e diretores - a proposta da política pública, em vias de implantação em algumas escolas do município. Assim, colaborou para que o dispositivo ainda inscrito na esfera das intenções - fosse transformado em objeto de desejo para o quadro da educação, pois

\footnotetext{
${ }^{35}$ Conforme mencionado anteriormente, a BEI da EMEF Roberto Mange foi o primeiro projeto de pesquisa visando o conceito de biblioteca escolar interativa, desenvolvido pela USP em parceria com a FAPESP.

${ }^{36}$ A partir de Rodrigues (2011, p.25), reforçamos a importância de que os sujeitos implicados nas instâncias decisórias demonstrem capacidade de interagir e negociar, de forma democrática, com os demais sujeitos envolvidos com o processo.
} 
Nessas visitas que foram sendo feitas [a BEI da EMEF Roberto Mange] as diretoras vinham e falavam "eu quero uma dessa, eu quero uma dessa..." (Dalva Franceschetti).

Da mesma forma, após a inauguração da primeira BEI de São Bernardo do Campo (criada após a intervenção da diretora da escola), foi elaborado um programa regular de visitas, para que os profissionais da educação conhecessem a biblioteca de perto e, principalmente, sentissem o ambiente. A comunicação de experiência bem-sucedida, entre aqueles que estavam diretamente envolvidos no circuito no qual a política pública seria implementada foi fundamental, na medida em que motivou os profissionais da educação a pressionarem o poder público, demandando a criação de mais bibliotecas. Conforme afirmado,

A partir dessas visitas que foram sendo feitas, os professores $e$ diretores começaram a pressionar o secretário [de Educação e Cultura] para criar bibliotecas (Dalva Franceschetti).

A demanda foi determinante para que a REBI se expandisse para a rede de escolas, pois a partir de então,

A Secretaria [de Educação e Cultura] discutiu que, se tem em uma, tem que ter em todas as escolas. $O$ que ofereço para um aluno tenho que oferecer para outro também. Não posso ter escolas com padrões diferentes. Se nós consideramos que a biblioteca escolar é importante para a aprendizagem dos alunos, é importante para aprendizagem de todos (Dalva Franceschetti).

Nesse sentido, a comunicação do resultado da ação política - ainda restrita a um pequeno contexto - a partir de argumentos concretos da realização inovadora, foi essencial. A estratégia indicava aos profissionais da educação possibilidades reais de um futuro a ser alcançado; projeção primordial para que os esforços, trabalho árduo, dificuldades e deslocamentos das possíveis zonas de conforto, implicados numa ação como esta, fossem superados pelos sujeitos, em busca de um resultado compensador.

Além da comunicação dos resultados obtidos para o quadro da educação, a política ocupou-se em explicitar os resultados em contextos externos,

Éramos convidadas para participar de congressos, para falar da biblioteca e também de outros programas que tínhamos. Recebíamos muitas pessoas do Brasil para fazer visitas, saber da nossa proposta. Temos reportagens, temos reportagem na revista Nova escola, com o Admir falando sobre a REBI, teve reportagem na rede Globo (Jumara Bulha). 
A política, transformada em objeto de discussão em contextos variados, confirmava seu caráter inovador no âmbito das bibliotecas escolares em nosso país. Conforme afirmado, a equipe chegou, inclusive, a

Apresentar esse trabalho no Salão do livro na França, tivemos quase uma hora de fala, porque realmente foi uma política de biblioteca escolar diferenciada no Brasil (Dalva Franceschetti).

O campo político também se concentrou em comunicar os resultados para a população em geral. De acordo com relato,

Foi um projeto de grande visibilidade esse das bibliotecas escolares, era carro chefe da administração. Estava nos outdoors, era garota propaganda. Outdoors na cidade dizendo temos tantas bibliotecas escolares, construímos tantas bibliotecas escolares com as fotos dos espaços (Dalva Franceschetti).

Se por um lado, a atitude pôs em evidência a propaganda dos feitos políticos - forma de comprovar resultados e estimular a aprovação do governo pela população -, por outro, destacou uma nova dimensão. A ação em torno das bibliotecas escolares era conhecida somente pelos sujeitos diretamente implicados com o ensino - profissionais da educação, alunos e seus pais. Assim, as demais parcelas da população não tinham contato direto com estes dispositivos e, muitas vezes, nem chegavam a ter conhecimento de sua existência nas escolas. De alguma forma, a propaganda política acabou comunicando para a população em geral que existia uma biblioteca escolar em implantação e, de alguma forma, pode ter contribuído para demonstrar a alguns a importância de investimentos públicos neste âmbito.

\subsubsection{Cenário Favorável}

A REBI surgiu em meio a um cenário permeado por elementos favoráveis que, embora não tenham constituído o planejamento político, devem ser considerados. Na experiência em discussão sobressaíram dois elementos, objetos de nossa atenção: o tempo para o desenvolvimento da ação e políticas mais amplas no âmbito da educação pública municipal. 


\subsubsection{O tempo para continuidade das ações}

A expansão do projeto para as escolas da rede pública de ensino fundamental foi favorecida pela continuidade da gestão política. De acordo com o secretário de Educação e Cultura

[As primeiras bibliotecas] foram implantadas no final de um governo, então não daria tempo de fazer mais naquele governo e também não tínhamos certeza de conseguir implantar isto em todas as escolas [...]. Então fizemos seis que foi o que deu para fazer com o recurso e o tempo que tínhamos. E nós colocamos isso no programa do governo, aí o prefeito foi reeleito e voltei para a Secretaria de Educação, assim, continuamos fazendo as BEIs de acordo com o orçamento, com as nossas pernas... Depois voltei para a SEC com outro prefeito e ai deu tempo para implantar mais, porque aí foram três mandatos. Quer dizer, um ano do primeiro, depois quatro dos outros dois, foram nove anos para que se implantasse na rede toda ${ }^{37}$ (Admir Ferro, grifo nosso).

A continuidade da gestão municipal parece ter sido determinante para a expansão, já que o tempo demandado para a consolidação de uma política pública desta natureza é diverso do tempo objetivo, que define as alternâncias na esfera de poder. No modelo de gestão predominante em nosso país são marcantes as descontinuidades nas políticas públicas, muitas vezes abandonadas, independentemente dos resultados positivos que possam trazer para a população. Em relação às bibliotecas escolares, o risco de rupturas é bastante provável, já que a população em geral ainda não possui vínculos efetivos com estes dispositivos - conforme problematizado ao longo deste estudo. Face a isso, decisões por descontinuar a REBI, naquele momento, talvez não fossem alvo de críticas da população, pois as BEIs apenas começavam a mostrar sua relevância.

O secretário de Educação e Cultura também revelou que a REBI

Era um projeto caro para os padrões da época, na verdade fui até criticado por algumas pessoas porque era um projeto caro (Admir Ferro).

37 Atualmente a Rede Escolar de Bibliotecas Interativas é formada por 91 BEIs. (Fonte: < http://www.educacao.saobernardo.sp.gov.br/index.php/bibliotecas-escolares >. Acesso em: 13 dez. 2014). 
Nessa perspectiva as chances de que ocorressem descontinuidades na ação política por conta de alterações na esfera de poder - eram altas, pois o investimento do volume financeiro envolvido com a ação era tido, por determinados segmentos, como gasto. Isto apenas confirma a incompreensão em torno da ação e, portanto, do valor das bibliotecas para a educação. O momento acabou pondo em foco a necessidade de que gestores, decisores e população compreendessem que políticas de qualidade, no âmbito da educação, demandam recursos, entendidos como investimentos, determinantes não só para a criação, mas, também para a expansão e consolidação das iniciativas.

Aliado às oportunidades decorrentes da permanência da gestão política, estava a certeza das profissionais da SBE de que o cenário favorável precisava ser otimizado

Foi muita vivência para poucos anos, foi muita coisa acontecendo e o mundo se modernizando e a gente querendo acompanhar tudo e muitas crianças para serem atendidas. Eu sempre tive essa noção do tempo político. Queria aproveitar o momento. A verba e a clareza do político que entendeu a nossa proposta, porque eu sabia muito bem o que era querer fazer e ninguém entender. Se a gente não aproveitasse naquele momento, e fizesse tudo e mais um pouco, implantar e acontecer, formar, produzir, etc., a gente não teria outro. E isso a equipe inteira entendia, a equipe inteira sabia disso, então todo mundo corria contra o tempo pra fazer tudo rápido (Cristina Bisognini).

Como fica evidente, os sujeitos diretamente envolvidos com a implantação da REBI tiveram um papel decisivo, compreendendo a importância de aproveitar o momento político favorável para consolidar a iniciativa. Foram além da execução técnica de um projeto, empregando esforços para transformar uma realidade considerada insatisfatória. Certas do importante papel da biblioteca escolar, as profissionais atuaram ativamente para que tais dispositivos fizessem parte da educação municipal.

\subsubsection{Políticas amplas no contexto da educação}

Tanto o surgimento como a expansão da REBI encontraram abrigo na municipalização do ensino que ocorria no país, momento em que a prefeitura de São Bernardo do Campo 
assumia a responsabilidade pelas escolas de ensino fundamental deste município, até então geridas pela Secretaria de Educação do Estado de São Paulo.

Com isso, os equipamentos foram alvo de reformas e diversos novos edifícios foram construídos, sendo que nesta empreitada a prefeitura decidiu incluir na planta das escolas, após os primeiros resultados das BEIs, um espaço destinado à biblioteca.

Teve uma diferença na cidade [...] de política pra educação. Isso foi claro, mudou a política pra educação e nesse bojo chega a BEI (Dalva Franceschetti).

Para exemplificar, constatamos que dentre as seis escolas inicialmente contempladas pela ação política, três enquadraram-se nesta condição. Ao serem assumidas pela prefeitura foram alvo de reformas, elemento que determinou a possibilidade de construção das BEIs.

De acordo com o secretário de Educação e Cultura,

Havia um conjunto de ações. O objetivo era fazer um ensino de qualidade e nós fizemos (Admir Ferro).

Destaca-se então que em grande medida a ação foi favorecida pelo amplo quadro de transformações na política para a educação. Foi atestado que reformulações políticas em quadros preexistentes podem contribuir para o surgimento de outras políticas públicas, implicadas no mesmo contexto ${ }^{38}$. Assim, cenários favoráveis criam oportunidades desde que os sujeitos ali implicados - seja o político, o profissional bibliotecário ou o educador vislumbrem possibilidades e atuem afirmativamente para transformar realidades.

\subsubsection{Quadro Profissional: Identidade na Diferença}

A REBI surgiu com a proposta de que profissionais de áreas distintas trabalhassem em rede. $\mathrm{O}$ quadro profissional foi constituído tendo em vista a articulação de saberes e fazeres dos campos da Educação e Informação, fundamentais ao desenvolvimento da REBI.

\footnotetext{
38 Em experiência anterior relatada por Pieruccini (2004) na tese de doutorado A ordem informacional dialógica: estudo sobre a busca de informação em educação, foi demonstrado que a implantação de biblioteca escolar, no Colégio Termomecânica, inseriu-se num quadro de renovação pedagógica pelo qual passava a escola. A experiência vai ao encontro de nossas afirmações, comprovando que um cenário de amplas transformações pode ser favorável à inserção de novas questões na agenda política.
} 
No contexto em questão, discussões corporativistas foram minimizadas, pois os sujeitos compreenderam que a BEI demandaria a atuação de diferentes categorias profissionais. Ademais, as possibilidades reais encontradas no terreno foram tomadas como meios para a definição do quadro profissional, fundamentalmente constituído por bibliotecárias e educadoras, que trabalharam de forma articulada, a partir de diferentes níveis de atuação, tendo em vista a implantação e desenvolvimento das bibliotecas escolares.

\subsubsection{Bibliotecários: um novo papel}

Além da bibliotecária que chefiava a SBE, a equipe contava com outras quatro que, sediadas na SBE, eram responsáveis pela gestão da Rede. Dalva Franceschetti, que primeiro foi bibliotecária da Seção e depois assumiu a chefia, assim se expressa sobre este modelo:

Embora eu seja bibliotecária, acho que o bibliotecário tem um papel de gerente, de coordenador nas redes de bibliotecas escolares. Ele não precisa estar lá na ponta atendendo (Dalva Franceschetti).

Cabia às bibliotecárias desempenharem o papel de coordenação da REBI, ou seja, uma rede de bibliotecas que pressupõe, de um lado, articulação entre as unidades e, de outro, autonomia de ação face à singularidade dos contextos particulares de cada uma delas. Assim, eram responsáveis pelo planejamento de diferentes atividades inerentes a REBI, tais como a gestão da informação, produção de informações sobre o acervo, proposição de formas de documentar a memória da comunidade escolar e seu entorno, identificação e proposição de novos e diferentes meios de apresentar a informação no espaço da biblioteca.

Dalva demonstrou que o modelo de trabalho adotado trazia resultados positivos para a ação, pois

O conteúdo pedagógico do professor, associado a nossa coordenação enquanto bibliotecários, juntando essas duas coisas, vimos que dava um resultado muito maior do que você colocar um bibliotecário que não tem esse lado pedagógico para trabalhar na biblioteca. Então, ter um quadro de bibliotecários coordenadores ainda, no meu entender, é o melhor formato para uma rede de bibliotecas escolares (Dalva Franceschetti). 
O relato evidencia que o formato de atuação buscou articular saberes e fazeres de cada segmento profissional, fundamentais para o desenvolvimento das BEIs. A própria bibliotecária demonstrou clareza quanto às especificidades das atividades de mediação, a serem desenvolvidas nas bibliotecas, reconhecendo que para a atuação direta com as crianças e jovens, o profissional da educação era fundamental. De outro lado, era inerente à expertise das bibliotecárias o trabalho direto com a organização e disponibilização da informação no contexto das BEIs, assim como a gestão das atividades referentes ao desenvolvimento destes dispositivos, baseados no conceito de biblioteca e educação.

\subsubsection{Orientadoras pedagógicas: gestão compartilhada}

Com o início da política pública, duas orientadoras pedagógicas - cargo já existente na estrutura administrativa da Secretaria de Educação e Cultura - foram integradas ao quadro profissional da SBE para desenvolverem atividades exclusivamente relacionadas à REBI.

Às orientadoras pedagógicas cabia a orientação e acompanhamento quanto ao uso das bibliotecas escolares pelos educadores. Para tanto, visitavam escolas e bibliotecas, participando de reuniões com professores, coordenadores, diretores e orientadores pedagógicos para verificar se as ações das BEIs estavam articuladas com as atividades da escola, planejadas no âmbito da SEC. Portanto, também mantinham contato direto com as PABEs para acompanhar o desenvolvimento das atividades das bibliotecas.

Era figura importante, fazia articulação do que estava sendo discutido com os orientadores pedagógicos, discutia a grade curricular, os parâmetros, o plano da escola, então fazia essa articulação para que as ações da biblioteca escolar estivessem articuladas com as ações da escola, discutidas pela Secretaria de Educação (Cláudia Sarro).

O cargo era eminentemente estratégico, na medida em que estas profissionais se ocupavam com a consolidação da biblioteca na escola, a partir de ações diretas junto aos profissionais da educação. Além do acompanhamento do papel da biblioteca, as orientadoras pedagógicas eram responsáveis por planejar e garantir que as ações, no âmbito das BEIs, estivessem integradas ao planejamento de ensino da SEC. Estavam, assim, em estreito contato com a equipe da USP, tendo em vista refletir e propor planos de ação para as BEIs. 
A função da orientadora pedagógica mostrou-se fundamental à REBI, na medida em que ela atuava como ponte, constituída para garantir vínculos entre biblioteca e sala de aula. $\mathrm{O}$ papel ia ao encontro da proposta, uma biblioteca efetivamente integrada ao ensino, demonstrando que a ação política contemplou a importância de diferentes níveis de atuação profissional, para que os objetivos almejados fossem alcançados.

\subsubsection{Professoras de Apoio à Biblioteca Escolar (PABE): criação de novos postos}

Atuando diretamente nas BEIs estavam as PABEs, professoras que já trabalhavam no sistema de ensino de São Bernardo do Campo, e que obtiveram o cargo por meio de processo de seleção interno. Inicialmente a REBI contava com seis destas profissionais, número que foi sendo ampliado com a expansão. Era função das PABEs objetivar em ações a integração da BEI com o planejamento pedagógico das escolas, papel de reconhecida importância para a gestão política:

Não adianta você dizer que a criança precisa ler, você tem que ter uma forma de incentivar isso, você não precisa incentivá-la a sentar no computador, mas, ela precisa ser incentivada à leitura. Então para isso é preciso ter todo um modelo e esse modelo da biblioteca com professor que recebia formação específica para tanto foi importante. Não adianta deixar a biblioteca aberta lá para o aluno que quiser, pois isso não o incentiva a entrar (Admir Ferro).

O ingresso da PABE como profissional da BEI foi, assim, visto como um avanço propiciado pela política de bibliotecas escolares. Uma das entrevistadas tem a seguinte percepção do papel desta profissional:

Foi extremamente inovador, as PABEs faziam basicamente um trabalho de mediação, você ter um espaço adequado, o material adequado, recursos informacionais adequados, com mobiliário, concepção arquitetônica ideal é um ganho, mas, se você não tiver o sujeito que faz uma mediação desse processo a coisa não funciona, $e$ a PABE fazia esse papel de mediadora. Ela não era bibliotecária, no sentido técnico. Então o trabalho técnico era feito por equipe técnica e esse trabalho de articulação do trabalho do professor, do projeto pedagógico da escola e a ação da biblioteca escolar como instrumento facilitador desse processo complexo que é a aquisição do 
conhecimento se dava a partir dessa interação entre a PABE e a equipe escolar (Cláudia Sarro).

Além das atividades desempenhadas diretamente com os alunos, a PABE era responsável por outras ações, tendo em vista consolidar a BEI na escola:

A PABE pensava em processos de formação, verificava a necessidade da escola em termos de formação, ela era uma ponte importante com as equipes de professores, desempenhava ações de formação, de intervenção, de produção de documentos. Atuava também em termos de entender quais eram as dificuldades da escola. Então acho que esse papel era fundamental, era basicamente de mediação de uma concepção nova que deveria ser construída num conjunto, dentro de um conceito de interatividade que exige muitos atores: a escola com sua equipe pedagógica, direção, professores, alunos e a SBE com a equipe gestora e a universidade, todos nesse processo (Cláudia Sarro).

Nesses termos, ela precisava estar integrada ao cotidiano da escola, em comunicação constante com os demais educadores, para conhecer aquilo que os alunos desenvolviam em sala de aula e, a partir disso, propor ações a serem desenvolvidas na BEI que dialogassem com as atividades das aulas, mas que também as extrapolassem, tanto quanto possível.

Portanto, a PABE tinha papel de "farol", de levar a BEI para fora de seu espaço, iluminando as ações da sala de aula com possibilidades ainda desconhecidas pelos quadros da escola:

A PABE tinha que participar de todos os momentos de planejamento da equipe escolar. Ela não era algo a parte, ela não tinha que receber o planejamento, ela tinha que estar na discussão. Então as PABEs participavam de todos os HTPCs das escolas, pois há vários, têm vários turnos, então tem à noite, no sábado. Era papel da PABE participar dos momentos de planejamento. A PABE tinha que procurar, sempre que possível, chegar no professor e pedir para ele qual era o planejamento da aula dele para a biblioteca. Não era aula de biblioteca, era assim "professor você está trabalhando o que na sua sala de aula. Então quando você for à biblioteca você quer saber antes o que há no acervo? Poderíamos planejar essa aula juntos?" Então ela selecionava dentro do projeto do professor, separava itens do acervo para que no momento em que a criança fosse à BEI, as coisas fossem integradas com o que ela estava vendo na sala de aula. Era um processo integrado (Dalva Franceschetti). 
A Professora de Apoio a Biblioteca Escolar era, portanto, a profissional que inovava o caráter da biblioteca "como coleção de livros à espera dos leitores". Ela atuava para além dos limites físicos da biblioteca, dialogava com o contexto escolar, mediando a concepção de BEI junto aos demais educadores. Esta "nova" função, de certa forma inventada no bojo e no movimento por uma política de bibliotecas escolares em São Bernardo do Campo, mostrou-se fundamental para angariar olhares favoráveis daqueles que passaram a se beneficiar pedagogicamente da biblioteca.

\subsubsection{Professoras de Apoio à Biblioteca Escolar - função Referência (PABEs Referência): ampliação de estruturas}

Além das PABEs que atuavam diretamente nas escolas, a REBI contava com a figura da PABE Referência. Eram profissionais que ficavam na Seção de Biblioteca Escolar e atuavam nas escolas no sentido de acompanhar e orientar na implantação das BEIs. Elas

Acompanhavam as ações da PABE que estava na escola. Desempenhavam diversas ações, desde o acompanhamento local até pensar ações de formação, quais seriam as dificuldades que as pessoas estavam enfrentando, pois aí ela encaminhava isto para a equipe técnica da Seção (Cláudia Sarro).

A criação de cargos ou funções, nesse caso, não significava hierarquia. A própria nomenclatura proposta - Referência - mostrava o papel de apoio da instância central às ações desenvolvidas pelas unidades locais. Nessa perspectiva, o trabalho articulado entre as PABEs foi fundamental para que as ações propostas para a BEI fossem renovadas, pois

As PABEs também traziam muita referência para a própria equipe do prof. Edmir, para que pudessem pensar as questões e desenvolver considerações, reflexões, interações. Quer dizer, 'olha tal situação não está funcionando, a forma como o acervo está organizado não responde, tem problema aqui na aquisição do material, na organização das grades, como a gente vai fazer ação cultural $e$ chamar a comunidade, como a gente vai trabalhar memória, como vai envolver a EJA...' Enfim, eram muitas as questões que surgiam e elas eram pessoas que estavam pensando, eram pessoas reflexivas que tinham uma vinculação importante com o processo educativo (Cláudia Sarro). 
O quadro profissional também comportou a figura de uma PABE Referência que, junto às bibliotecárias, dedicava-se exclusivamente ao desenvolvimento do acervo das BEIs. Neste âmbito também teve atuação fundamental, na medida em que contribuía com saberes específicos de sua formação para a aquisição de recursos informacionais significativos para as atividades propostas no âmbito das bibliotecas.

Diante disto, tanto a articulação de profissionais distintos como a estrutura de trabalho em rede mostrou-se fundamental, deixando claro que não estava em pauta a atuação em unidades isoladas. A política pública não partiu do cada um por si, revelando a importância da integração de todos os profissionais envolvidos com a ação, tendo em vista a consecução de uma rede de bibliotecas escolares.

\subsubsection{Formação dos Profissionais}

A ação efetiva da biblioteca junto à sua comunidade seria o grande veículo da consolidação das BEIs no contexto das escolas. E para isso, a redefinição das bibliotecas e expansão da Rede demandaria recursos humanos que levassem a proposta adiante, transformando a intenção em ação concreta, nos termos da inovação conceitual e metodológica do projeto da REBI.

Os contextos político e administrativo foram favoráveis, ao compreenderem que o investimento nas bibliotecas escolares não se resumiria aos equipamentos físicos, mas, sobretudo, demandaria a formação dos profissionais diretamente envolvidos com as BEIS, para que se apropriassem dos referenciais que pautavam o projeto.

Nessa perspectiva, a equipe da USP desenvolveu ações de formação continuada, com início prévio à inauguração das bibliotecas, tendo perdurado ao longo do convênio firmado com a prefeitura. O amplo programa de formação incluía professores e pesquisadores vinculados à universidade, que trabalharam conceitos e métodos da biblioteca escolar em implantação. A fala de uma PABE atesta a relevância conferida ao processo formativo:

Muito do avanço do projeto se deveu a essa equipe que pensava nas formações e pensava em como mediar todas essas questões de concepção e encaminhamento das ações dentro das escolas (Cláudia Sarro). 
Esta dimensão da política pública demonstrou a importância de ações formativas permanentes. A complexidade da ressignificação da biblioteca escolar veio à tona a partir do planejamento de ações de formação variadas, junto às diferentes categorias profissionais relacionadas à REBI.

\subsubsection{Formação dos Profissionais da Seção de Biblioteca Escolar}

Novos cargos e funções demandam formação, tendo em vista quadros capazes de atuar em sintonia com as concepções. As atividades de formação envolveram todas as profissionais da SBE: bibliotecários, orientadores pedagógicos e PABEs, que dariam sustentação ao projeto e desenvolveriam ações no âmbito das BEIs.

\subsection{Bibliotecárias: ressignificação da experiência profissional}

A formação das bibliotecárias ocorreu desde o início das ações, para que estas profissionais atuassem a partir da concepção proposta pela universidade. Conforme relato de participante do processo,

A formação era 'virtual'. Então a gente ia visitar a BEI da EMEF Roberto Mange assim como outros espaços e as formações iam acontecendo. Porque a primeira biblioteca foi inaugurada em dezembro de 2000 e a formação já estava acontecendo desde 1999 (Dalva Franceschetti).

A ação compreendia a discussão dos eixos de atuação da biblioteca na escola e a compreensão das diversas dimensões implicadas num projeto como este, que envolvia desde o planejamento e implantação de organismos físicos até o desenvolvimento e manutenção de ações permanentes junto à comunidade escolar.

A formação das bibliotecárias foi essencial, na medida em que atuavam na gestão da REBI e, portanto, apropriarem-se da proposta seria indispensável. De acordo com Perrotti, a ideia era que 
Formássemos os gestores para que eles se apropriassem efetivamente das ideias, da rede, e daí pudessem ganhar independência e tocar o projeto por conta própria, uma vez que não podíamos apostar num modelo que ficasse eternamente dependente da universidade. Ao contrário, tínhamos que criar um processo que pudesse dar autonomia para eles e depois, se precisassem, continuar o diálogo em alguns momentos, mas, do ponto de vista de construção, desenvolvimento da rede e unidades que a compõe, eles tivessem autonomia para poder levar o projeto (Prof. Dr. Edmir Perrotti).

Nesses termos, a formação também objetivava que a política pública para bibliotecas escolares em São Bernardo do Campo ganhasse sustentabilidade plena, posteriormente. Independentemente da universidade, a SEC seria autônoma para alimentar e dar continuidade a REBI, mantendo princípios, processos e produtos indispensáveis à qualidade e exigências implícitas ao projeto.

As ações visavam que os próprios gestores compreendessem o significado de suas ações na constituição da REBI, assim como a importância da inclusão de seus saberes na configuração desse novo dispositivo. Tal dimensão foi encarada como essencial à continuidade dos processos, para além do período firmado pelo convênio que garantia a participação da equipe acadêmica.

Por sua vez, com a expansão da REBI houve bibliotecárias que receberam formação específica para atuar diretamente na formação dos professores da rede de ensino, sob supervisão da equipe da USP. De acordo com uma das bibliotecárias

Começamos a ser multiplicadores. Então ai eu entrei no processo como formadora. A gente recebia formação, eu e as professoras de apoio, porque a preocupação é que essa biblioteca não fosse vista somente como um espaço bonito (Dalva Franceschetti).

Nesse contexto, sobressaiu uma ação política voltada à formação das profissionais para que atuassem em sintonia com a proposta, bastante inovadora e que, portanto, demandava o aprendizado de diferentes elementos implicados na constituição de bibliotecas sob o paradigma da apropriação cultural. O fato das bibliotecárias terem ensino superior não significou que não precisariam passar por formação, ao contrário, foi reconhecida a importância de investimentos para formar as gestoras do inovador projeto em desenvolvimento. 


\subsection{Professoras de Apoio à Biblioteca Escolar e Orientadoras Pedagógicas}

As PABEs e orientadoras pedagógicas passaram por formação continuada constante para se apropriarem do novo conceito de biblioteca escolar. Conforme relato,

Acho que todo o trabalho de formação foi feito no sentido de garantir uma concepção de biblioteca escolar diferente, digamos assim, do que a gente estava acostumado a entender como biblioteca escolar (Cláudia Sarro).

Nesse sentido, a formação destas profissionais se revelou essencial à política, pois seriam elas que concretizariam no terreno a proposta de biblioteca escolar interativa:

Se não você tinha a biblioteca pronta para esse trabalho interativo, mas o professor trabalhava daquele jeito tradicional. Então a gente precisou capacitar muito para que a PABE promovesse a interação entre as crianças e a biblioteca (Jumara Bulha).

Para tanto, foram realizadas atividades diversificadas:

\section{- Diálogo com a Nova Concepção a Partir de Experiências Concretas}

Antes da inauguração das bibliotecas, as professoras responsáveis pelas BEIs passavam por intensa atividade formativa.

Essa formação, em seu formato inicial, incluiu um estágio internacional, para que as PABES e as gestoras da REBI conhecessem bibliotecas escolares e outros dispositivos culturais na França, tendo em vista a relevância da ampliação de horizontes e referências culturais dos profissionais que atuariam na rede. De acordo com Cláudia Sarro,

Fizemos um estágio nos espaços de informação na França, conhecemos, digamos, espaços importantes e como a informação e o conhecimento eram tratados nesses espaços, inclusive nas escolas. Como as crianças eram inseridas desde a tenra idade nesse processo de leitura e aquisição do conhecimento com vários materiais já com uma minibiblioteca dentro da sala de aula (Cláudia Sarro).

O estágio permitiu que as profissionais conhecessem dispositivos alinhados à concepção da REBI e, até mesmo, o avanço da proposta em relação a alguns contextos internacionais. $\mathrm{O}$ investimento deixava claro que a política pública era fundamentada em bases conceituais que compreendiam a importância dos recursos humanos que constituiriam a 
REBI, reforçando, portanto, que estava em causa muito mais que a mera criação de espaços físicos.

Nesse momento inicial, as profissionais também conheceram diferentes dispositivos de informação e cultura, tendo em vista a discussão do referencial conceitual que pautaria o trabalho nas BEIs. Conforme Cláudia Sarro afirmou,

A gente fazia visitas, por exemplo, conheceu a EMEF Roberto Mange, discutia questões. Também fomos à biblioteca em que a Ivete desenvolvia ações sobre a memória ${ }^{39}$... Discutíamos esses conceitos também para desenvolver os eixos de ações da biblioteca. Então eram várias ações no sentido dessa formação, houve também estudo em bibliografia (Cláudia Sarro).

O processo revela, assim, que a política partia da necessidade de que junto com a inauguração dos espaços viesse a figura de uma nova profissional de interface entre informação e educação, pois o objetivo era a inserção de uma nova prática nas escolas e não somente a criação de novos espaços.

\section{- Teoria e Prática: Elementos da Continuidade}

Após a inauguração das BEIs, as atividades de formação continuaram e, além do estudo de bibliografia, incluíram a discussão das experiências vivenciadas nas bibliotecas. Os resultados das ações realizadas, as dificuldades encontradas no terreno bem como as formas de superá-las passaram a ser alvo das formações, que tiveram como uma de suas bases a troca de experiências entre as profissionais da REBI. De acordo com relato,

Tínhamos reuniões com o prof. Edmir Perrotti, tanto o conceito de biblioteca escolar como as práticas que estávamos tendo eram discutidos dentro do grupo. Refletíamos se estava dentro da concepção, enfim, a gente fazia uma reflexão sobre nossas ações nessa equipe de formação direta com o Edmir (Cláudia Sarro).

Estava em pauta a articulação dos saberes teóricos com os saberes da ação, adquiridos no contexto vivo da atuação na BEI, para que as profissionais pensassem sobre suas atividades. Dimensão fundamental, na medida em que pensar "não significa simplesmente

\footnotetext{
${ }^{39}$ Trata-se da biblioteca pública Álvaro Guerra, situada na cidade de São Paulo. Nesta biblioteca foi inaugurado em 1997 um novo dispositivo informacional: a Estação Memória, dedicada a trocas culturais entre idosos, crianças e jovens. O conceito de Estação Memória foi criado por Edmir Perrotti e vem sendo desenvolvido por meio de pesquisas coordenadas por Ivete Pieruccini.
} 
mover-se no já pensado, mas recomeçar e, precisamente, recomeçar através das provações impostas pelo acontecimento" (LEFORT, 1991, p.65). Em face disso, a metodologia adotada nesta fase foi o trabalho em rede, com ênfase em encontros para troca de experiências, compartilhamento de questões concretas de diferentes ordens encontradas no terreno e reflexão conjunta, para busca de soluções aos desafios encontrados no cotidiano da implantação das diferentes unidades.

A experiência de implantação da REBI chegou mesmo a ser publicada, pois, paralelamente, parte da equipe de pesquisadores vinculados a USP produziu materiais para subsidiar a continuidade da formação, eram os Cadernos REBI. A produção, impressa em 2007, foi resultante do acúmulo de experiências do percurso formativo, que envolveu teoria e prática, deixando referenciais para apoio a este trabalho, específico e inovador de implantação de uma rede de bibliotecas escolares no país.

\subsubsection{Formação dos professores, diretores e coordenadores de escolas}

Professores, coordenadores e diretores das escolas passaram por formação, que se dava em horário de expediente e, também, fora dele. Incluída como parte do processo de implantação e consolidação das bibliotecas escolares, a formação dos quadros das escolas propiciaria a socialização dos princípios, finalidades e perspectivas da biblioteca na escola, sobretudo, face às (sabidas) representações que povoam nosso imaginário, no que tange à biblioteca em nosso país. Tratava-se, segundo relato, de mostrar diferenças e buscar aproximações historicamente negadas aos públicos em geral:

Antes de inaugurar as bibliotecas percebeu-se que seria importante a gente [as PABEs] ir para a escola fazer um trabalho de aproximação para que o processo fosse participativo e interativo desde o começo, construindo toda uma fundamentação em termos de importância pedagógica [...]. Então desde o começo a equipe da escola foi envolvida nesse processo. Fomos fazendo um trabalho de interação da biblioteca para que quando estivesse pronta muito dos conceitos já tivessem sido apropriados pela escola e pela direção (Cláudia Sarro).

As ações ocorriam no sentido de discutir a concepção da biblioteca escolar e a importância de todos os seus elementos constitutivos. Até mesmo a proposta arquitetônica era 
alvo de formação para demonstrar que as cores, mobiliário e disposição do espaço foram planejadas a partir de estudos elaborados por pesquisadores com ampla experiência na área. Logo,

Tinha formação [nas escolas] para explicar as cores aos professores [...] Então a formação era muito rica para que saísse dessa ideia de que era um espaço bonito (Dalva Franceschetti).

Os conteúdos das formações eram bastante diversificados, porque estava claro que o papel da biblioteca seria desempenhado no constante diálogo com as ações pedagógicas de sala de aula e, nesse sentido, a compreensão dos professores acerca do potencial da biblioteca no processo de ensino-aprendizagem era essencial. O relato de Cláudia Sarro atesta a afirmação,

Receberam muitas formações, teve formação de como o acervo era organizado, tinha sobre a questão da leitura, da memória, literatura infantojuvenil, pesquisa, leitura de ficção. Foram feitas várias formações com a equipe do prof. Edmir (Cláudia Sarro).

No início, a equipe da USP era quase que exclusivamente responsável pelo desenvolvimento das formações. Com a referida expansão, as PABEs e também uma bibliotecária começaram a participar dessas atividades, com a assessoria da equipe da universidade. De acordo com a bibliotecária,

Então a gente falava de toda essa concepção de espaço e das práticas pedagógicas, que práticas são essas dentro de uma biblioteca escolar, que o princípio era que a PABE tem que participar de todos os momentos de planejamento da equipe escolar (Dalva Franceschetti).

Diante disto, restou evidente a importância de que todos os profissionais inseridos no contexto da educação se apropriassem das concepções em causa. Uma ação de formação voltada somente às PABEs e às bibliotecárias seria insuficiente, na medida em que todo o potencial da BEI seria revelado a partir do diálogo entre biblioteca e sala de aula. 


\subsubsection{Instâncias de Negociação: Consolidar o Papel da Biblioteca na Educação}

O processo de implantação da política de bibliotecas escolares, em São Bernardo do Campo, considerou prováveis resistências do terreno e, com isso, estabeleceu mecanismos para superá-las. A medida partiu da constatação de que a biblioteca não é necessariamente uma unanimidade na rede de educação, na qual alguns profissionais chegam a considerá-la dispensável para o aprendizado formal.

Diante da implantação das bibliotecas escolares num contexto permeado por

Um desconhecimento que não é só do funcionamento, é do que é a coisa em si [foi reconhecida a necessidade de] negociações, porque é nossa tradição achar que você cria biblioteca e vai botar goela abaixo da população (Prof. Dr. Edmir Perrotti).

De fato, esta dimensão da ação mostrou-se essencial, pois as resistências encontradas inseriam-se em um quadro maior, marcado pela incompreensão do conceito de biblioteca escolar que estava sendo proposto. Não houve somente negação à criação das bibliotecas, mas, sobretudo, pairavam indefinições quanto ao papel daquele dispositivo no processo de ensino-aprendizagem. Nesse sentido, a política reconheceu que

Todo processo de mudança é um processo conflituoso, não é linear, exige muitas reformulações em termos de concepções e ações (Cláudia Sarro).

E, com isso, admitiu-se que seria inócuo implantar bibliotecas escolares, já que não basta criar espaços físicos e dizer "pronto, agora vocês têm uma biblioteca. Usem!", pois, por mais bem equipadas que fossem, seu papel na aprendizagem seria mínimo se outorgadas aos educadores, sem mediações compatíveis com os objetivos de apropriação propostos.

Em face disso, foram planejadas diferentes instâncias de negociação junto aos professores, coordenadores e diretores de escolas, para consolidar o papel da biblioteca na escola, de acordo com as concepções em causa. A proposta era que diferentes categorias profissionais da Seção de Biblioteca Escolar (SBE) - PABE, PABE Referência e chefe da Seção - interviessem nos casos de resistência por parte da escola. A atuação ocorria de forma articulada, também envolvendo interlocuções junto aos pesquisadores da USP, tendo em vista refletir sobre possíveis antídotos para superar as adversidades. 


\subsubsection{Primeiro nível de negociação: PABE}

Além de realizar atividades diretamente com os alunos, a PABE estava apta e disponível a responder às adversidades encontradas nas escolas. Por sua posição privilegiada - envolvida diariamente com o contexto escolar - encontrava-se num primeiro nível de negociação.

As PABEs foram mediadoras da concepção de BEI junto ao quadro de educadores, buscando que se apropriassem da biblioteca escolar. A atuação para além dos limites físicos da biblioteca mostrou-se essencial, já o potencial da biblioteca se revelaria a partir da integração de seus fazeres aos da sala de aula e, para tanto, o papel dos professores seria essencial.

Assim, diante de uma recusa à biblioteca, seja da parte de um professor ou diretor, a PABE que atuava diretamente na escola buscava dialogar, explicitando a importância daquela proposta para o aprendizado dos alunos. Era colocada em discussão a importância da biblioteca escolar sob o paradigma da apropriação cultural, para que os alunos se relacionassem com informação e cultura na condição de protagonistas, extrapolando a condição de consumidores de informações que assimilam conteúdos.

Não foi tarefa simples fazer com que todos os professores se apropriassem da concepção de biblioteca escolar como dispositivo integrado às práticas da sala de aula, espaço dinâmico dedicado a propiciar formas variadas de colocar o aluno como produtor de conhecimento. De acordo com relato,

Era uma fala que havia, que professor vai para a biblioteca só para ver vídeo. Era preciso quebrar com isso: "professor a biblioteca tem muito mais potencialidade”, "não, eu vim ver esse vídeo”. Porque, assim, esse professor estava cansado, então no horário que era da biblioteca "ah... me deixa, botar um vídeo". Tinha professor que mandava de castigo para a biblioteca (Dalva Franceschetti).

Além das posturas que demonstravam falta de entendimento sobre os saberes e fazeres implicados na biblioteca, havia posicionamentos de incompreensão quanto ao papel a ser desempenhado pelos educadores. Conforme relatado, 
Alguns professores, por exemplo, entendiam que iríamos assumir a sala para eles, então, por exemplo, eles levavam as crianças entendendo que a gente ia assumir um papel que era deles como se fosse mais uma aula que a gente ia dar. Eles não entendiam que aquela era uma ação conjunta (Cláudia Sarro).

Neste ambiente de indefinições, foram diversas as interlocuções com os educadores para que compreendessem a proposta da BEI, assim como a importância de sua participação efetiva nas atividades junto à biblioteca. Para Cláudia Sarro, foi preciso

Muita discussão para os professores entenderem que a apropriação era uma apropriação coletiva do espaço e que a gente estava lá como um meio facilitador, assim como ele, no processo com a criança, e, como a gente tinha mais informação, porque recebia essas informações com a formação com a equipe do professor Edmir então tínhamos mais condições de fazer essa mediação em termos da estrutura das questões informacionais, mas, a ação pedagógica era e continuava sendo dele, do professor. A gente estava lá para contribuir com o processo de leitura, de pesquisa, de construção de conhecimento que ele já deveria ter começado na sala de aula e que já faz parte da própria concepção educativa de pensar o ensinoaprendizagem a partir da construção do conhecimento e que a biblioteca era um espaço privilegiado nessa construção do conhecimento (Cláudia Sarro).

A formação recebida pela PABE contemplou o enfrentamento de adversidades do terreno, assim, o ingresso da biblioteca na escola se deu a partir da previsão de que haveria resistências ao projeto. A PABE não desistia frente a uma recusa e as dificuldades encontradas eram levadas aos encontros com a equipe de formação da USP para que, em conjunto, fossem pensadas estratégias de atuação, nos casos em que, por conta própria, ela não tivesse obtido sucesso. Portanto,

Ela tinha ações de intervenção, de produção de documentos de reflexão em termos de também entender quais eram as dificuldades da escola, trazia isso para a SBE para que as coisas pudessem ser pensadas e refletidas a partir da realidade da escola. Então varias ações eram pensadas a partir dessa observação que ela fazia no espaço, na realidade (Cláudia Sarro).

Negociavam junto à escola, pois compreendiam que as adversidades do terreno não podiam ser tomadas como naturais e inabaláveis. As PABEs foram preparadas para insistir nas negociações com os educadores, reconhecendo que a proposta da BEI interferia, em 
alguma medida, na prática de ensino da sala de aula. Portanto, sabiam que a biblioteca poderia causar mal-estar em alguns profissionais que, de algum modo, poderiam se sentir ameaçados pela nova proposta, que acabava provocando reflexões sobre a própria prática da sala de aula:

A BEI mexeu com todo um conceito de educação. Você entra na escola, ainda hoje, as carteiras estão enfileiradas, uma atrás da outra, e o professor lá na frente do quadro negro, quer dizer é um conceito de educação. Então, assim,nesse conceito não precisa de biblioteca escolar (Dalva Franceschetti).

A insistência, bem como a capacidade de projetar distintas estratégias, para resolver situações problemáticas, mostraram-se importantes para conquistar o papel da biblioteca no ensino. Um relato sobre situação específica, auxilia a compreender essas ações

Havia uma professora que não ia à biblioteca no seu horário estipulado na grade. A PABE batia na porta da sala de aula dela e ela sempre tinha uma desculpa: ' não dá, estou terminando uma atividade com eles, o projeto está atrasado'. No horário de planejamento, a PABE falava com ela e ela dizia 'eu não preciso de biblioteca, sempre dei aula desse jeito, a biblioteca não faz nenhuma diferença. Depois tem isso de emprestar livros, eu não sei o que os alunos irão levar, depois eles não devolvem...Não quero ter responsabilidade sobre isso' . Assim, a PABE argumentou 'se você levar os alunos lá no horário, eu vou ensiná-los a fazer o empréstimo e assim você não se preocupa...' . Depois disso, a PABE contou que no primeiro dia a professora não foi, foram os alunos e, então, quando eles viram podiam pegar sozinhos os livros, fazer o empréstimo mexer no computador e tudo o mais, nossa aquilo foi uma festa, todo mundo queria. Com o tempo, essa professora virou a maior fã da biblioteca, incluía a biblioteca em todos os projetos dela, porque ela percebeu né... O aluno começava a pedir 'professora você não vai no horário da biblioteca?" Ela percebeu a evolução, todos estavam lendo, melhorando, com isso, ela começou a ir nos horários que tinha que ir (Dalva Franceschetti).

Esta dimensão evidenciou que a ação política favoreceu a apropriação da BEI pela escola, pois, além de contemplar a formação dos educadores, ${ }^{40}$ previu a necessidade de que a profissional da BEI desempenhasse papel de negociadora daquela proposta junto à comunidade escolar. Nesse sentido, uma atuação passiva, aguardando que alunos e professores adentrassem na biblioteca, não favoreceria que o potencial da biblioteca fosse

${ }^{40}$ Anteriormente discutida no item 5.6.2 Formação dos Professores, Diretores e Coordenadores de Escolas. 
reconhecido pelos educadores. A PABE tinha como uma de suas funções comunicar a concepção inovadora aos professores e diretores, propondo ações conjuntas para que reconhecessem a importância da biblioteca no processo de ensino-aprendizado.

Por sua vez, nas situações em que a recusa era ferrenha, a PABE reportava o problema à segunda instância de negociação: a PABE Referência.

\subsubsection{Segundo nível de negociação: PABE Referência}

Nos casos problemáticos em que a mediação da PABE era insuficiente, a PABE Referência lançava-se em negociações com professores e, também, com a coordenação da escola. Na estrutura da REBI cada PABE Referência era responsável por acompanhar um determinado número de BEIs - que variou conforme a expansão -, idealmente fazendo uma visita semanal a cada biblioteca.

A PABE que atuava diretamente na escola reportava as situações problemáticas a PABE Referência e, a partir daí, ela interferia. A relação entre ambas, portanto, era de parceria

A PABE da escola tinha uma relação muito forte com a PABE Referência. Ela não achava que estava sendo avaliada, era uma relação de parceria. [...] Elas ligavam [para a PABE Referência] "você não está vindo, estou precisando conversar" (Dalva Franceschetti).

O modo de relacionamento entre as profissionais dos diferentes níveis foi fundamental para que se instalasse uma confiança mútua entre as partes. A profissional da biblioteca precisava sentir-se confortável para reportar adversidades, evitando possíveis omissões, por conta de sentimentos de incompetência face às dificuldades. De outro lado, a intervenção da PABE Referência era importante, na medida em que deixava claro - tanto para a profissional da BEI como para os educadores - que a biblioteca não havia sido alvo de ação fortuita. Havia uma política pública em curso, que contava com uma estrutura de profissionais voltados à consolidação das bibliotecas nas escolas.

Por sua vez, os distintos níveis de negociação mostraram-se importantes, face ao desconhecimento sobre o papel da biblioteca pela própria escola, e a gestão da SBE 
reconhecia que o contexto de implantação das BEIs era permeado por resistências, pois conforme afirmado,

Quando a gente vem com esse projeto de implantação desse conceito de biblioteca escolar tem que romper com toda essa cultura que as pessoas trazem de biblioteca escolar (Dalva Franceschetti).

Em face deste cenário, quando era requisitada sua intervenção, a primeira ação da PABE Referência era

Conversar com a equipe de gestão [da escola]. Então a PABE Referência ia e falava "olha conversei com a PABE, vocês querem que a gente venha no HTPC e explique o papel da PABE, querem que a gente faça tal tal ...". Às vezes a coordenadora falava "sim" às vezes "não". Nesses casos era "Então dá para conversar, dá para você coordenadora fazer essa fala do porquê a BEI é importante. Então fazia primeiro essa negociação (Dalva Franceschetti).

Assim, a negociação também era levada para outra instância do contexto escolar, ou seja, a PABE Referência não dialogava diretamente com os sujeitos implicados na situação problemática, e sim com a equipe gestora da escola. Nesse caso, as profissionais da SBE também reconheciam a importância de um diálogo com distintos interlocutores para evitar que características pessoais de um diretor pudessem determinar negativas à biblioteca. Portanto, face à constatação de que a proposta não seria plenamente compreendia por todos os profissionais da educação, as gestoras da SBE articularam estratégia de negociação que previa o diálogo em conjunto com diferentes sujeitos diretamente envolvidos com a gestão da escola. Conforme afirmação,

Geralmente não conversavam sozinhos. Conversava com a equipe de gestão, diretora, professora de apoio pedagógico e professora de apoio administrativo, para não ficar no enfoque de um, de repente a diretora era autoritária (Dalva Franceschetti).

Novamente, vale destacar, que as ações da PABE Referência eram levadas às formações com a equipe de pesquisadores da USP, responsável por discutir as soluções praticadas e iluminar novas alternativas. A dimensão era importante, também, para que os pesquisadores entrassem em contato com as questões que surgiam da experiência cotidiana na biblioteca, propiciando que refletissem sobre a validade das soluções propostas. 
Por fim, quando as negociações com a PABE Referência eram infrutíferas, o problema era reportado à chefe da SBE, terceiro nível de negociação.

\subsubsection{Terceiro nível de negociação: chefe da Seção de Biblioteca Escolar}

No âmbito da apropriação da BEI pelas escolas, a chefe da Seção de Biblioteca escolar (SBE) representava o terceiro nível de negociações. Assim, nos momentos em que a mediação da PABE Referência não surtia os efeitos desejados, ela entrava em cena para dialogar diretamente com os gestores das escolas.

Os diferentes níveis de negociação novamente mostraram-se importantes, pois em certos casos, a estrutura hierárquica de cargos e funções determinava a aceitação ou recusa, do gestor, em dialogar com os profissionais da REBI, já que

Às vezes a PABE Referência não conseguia, falavam para ela "estou ocupada, não vou atender, conversa lá com a PABE, assunto de biblioteca é lá com ela" (Dalva Franceschetti).

Nesses casos, a intervenção da chefe da SBE foi fundamental e, de acordo com afirmação, a negociação se dava

Sempre tentando entender porque a coisa não acontecia, onde estava o nó (Dalva Franceschetti).

Além disso, nestes momentos, era reforçado que a biblioteca escolar era objeto de política pública e as escolas deveriam atuar de acordo com as decisões da Secretaria. Nesses termos, nos casos de permanente recusa, em que o diálogo não apresentava resultados, a SBE atuou de forma impositiva, pois conforme afirmado

Não era se eu quiser, tem que ir, porque não basta a biblioteca estar na escola se o professor decide não usar. Então você faz o investimento, tem uma proposta pedagógica e aí fica na mão do professor decidir? E o direito desses alunos de usufruir do espaço? Então isso era imposto, todos os alunos têm que passar uma vez na semana na biblioteca (Dalva Franceschetti).

Esta dimensão revela uma nuance importante da política pública. Se por um lado a imposição, sem dúvida, possuía dimensão negativa - na medida em que podia determinar o 
aumento da recusa e, assim, distanciar a biblioteca dos sujeitos -, por outro, ela só ocorria nos casos em que a negativa teimava em imperar. Diante disto, a insistência em consolidar a BEI foi marca do processo, revelando que uma política em torno de bibliotecas escolares implica acompanhamentos, já que o senso comum é, muitas vezes, forte o suficiente para fazer sucumbir propostas de caráter mais inovador. O novo assusta e provoca deslocamentos, que nem todos estão preparados a enfrentar, mas, é preciso insistir na ação, buscando argumentos e alternativas que desarmem resistências prejudiciais.

De outro lado, a chefe da SBE também participou de inúmeras negociações para tratar da criação da biblioteca nas escolas. Embora frutífero, o processo também foi permeado por tensões, que revelavam incompreensões em torno do projeto. De acordo com relato,

Era tudo discutido, a escola não tinha autonomia para fazer diferente, tinha que estar no conceito. Fomos muito criticados por conta disso: "vocês são autoritárias", mas era um conceito de biblioteca e não podíamos deixar que o conceito se perdesse (Dalva Franceschetti).

As críticas, que denunciavam uma possível postura autoritária, eram rebatidas com discussões a respeito do conceito de biblioteca em questão. A chefe buscava demonstrar aos gestores que todos os elementos constitutivos da biblioteca eram dotados de intencionalidade, considerando-se o referencial conceitual que pautava a concepção da BEI. Apesar das críticas, a coordenação da Rede Escolar de Bibliotecas Interativas (REBI) manteve-se firme, segura de que a implantação das bibliotecas escolares, dentro da concepção proposta, sofreria ataques, até mesmo pelo desconhecimento de seu caráter inovador pela comunidade escolar. Tratavase, portanto, de avançar firmemente na travessia, colocar a BEI para funcionar e aguardar o aparecimento dos primeiros resultados, para que a relevância dos investimentos fosse realmente compreendida. A biblioteca falaria por si mesma.

\subsubsection{O Papel da Comunidade na Política Pública: Tempo, Informação, Negociação}

Na implantação da REBI, além da destinação de verba específica, foi adotado um modelo diferenciado para a gestão dos recursos financeiros que seriam utilizados para construir e equipar as bibliotecas escolares. Na perspectiva de agilizar o processo, optou-se pelo repasse das verbas públicas para a Associação de Pais e Mestres (APM). 
O modelo, que incluía e corresponsabilizava pais de alunos nos processos decisórios e no controle do investimento financeiro feito nas escolas, não era circunscrito somente às bibliotecas escolares, mas, foi adotado para toda a rede de ensino. Sobre esta decisão, o secretário de Educação e Cultura argumentou que

Havia muita dificuldade para reformar as escolas, pequenas reformas... Precisava trocar parte do telhado, precisava trocar piso do banheiro, louças, enfim, para essas pequenas reformas, na época, tínhamos que fazer uma concorrência e isto para cada situação dessas. Concorrência demora e quando fica pronto você já tem outros problemas na escola e não pode fazer algo novamente por aquela concorrência, tem que fazer por outra. Assim, era um trabalho enorme e um preço bastante alto, pois na concorrência você não consegue preço baixo, além disso, nunca ficava bom e quando terminava a comunidade já estava reclamando e, além de tudo, demorava muito. Quando municipalizamos as primeiras escolas do Estado, na verdade 20 escolas de uma só vez, nós nos deparamos com aqueles prédios muito deteriorados e necessitando de reformas. Depois de muita discussão e uma aprovação do jurídico da Prefeitura, começamos a utilizar esse modelo de repasse de verbas para a APM. Até então não se falava em biblioteca, nesse momento era deixar a escola em condições, bonita. Fizemos e deu certo, em um ano nós conseguimos reformar as escolas com os pais fazendo isto e como deu certo acabamos implantando esse modelo na rede (Admir Ferro).

A decisão desvendou que, muitas vezes, é fundamental a redefinição de práticas administrativas, para que resultados sejam alcançados de modo eficaz. Nesse sentido, o protagonismo daquele que conhecia as especificidades da administração pública foi primordial para que os procedimentos burocráticos fossem ultrapassados, a favor de soluções melhores e mais ágeis aos problemas públicos.

Sobre o modelo de gestão então adotado, Dalva Franceschetti expressou que

Eu particularmente acho que [o repasse de verbas para a APM], com essa agilidade de implantação, foi um dos processos que garantiu a qualidade das escolas que temos hoje (Dalva Franceschetti).

Nessas circunstâncias, a REBI beneficiou-se da decisão política que remodelou procedimentos de gestão de recursos financeiros destinados às escolas. Além da agilidade que conferiu ao desenvolvimento das bibliotecas, a opção possibilitou que fossem criadas de acordo com a concepção em causa, o que poderia não ocorrer numa compra por meio de 
processos de licitação e concorrência em que, com frequência, não é possível realizar ações conforme planejadas, tendo em vista atender a questões públicas.

Embora a intenção política tenha sido conferir agilidade aos processos públicos referentes aos contratos para prestação de serviços e às compras de materiais, o formato extrapolou esta dimensão, pois acabou desencadeando um novo modo de relacionamento com os pais de alunos, que participaram ativamente das decisões relativas à implantação. Assim,

A APM participava da planta, participava das reuniões com a professora Cibele ${ }^{41}$, porque eles é que iriam aprovar a contratação do engenheiro, da empresa que ia reformar todo o espaço. Então eles participavam, davam palpite, nas cores principalmente. A professora Cibele acatou muitas coisas (Cristina Bisognini).

Nesse modelo, a compra de mobiliário, equipamentos, contratação de serviços e materiais de construção era toda feita pela APM que, após, prestava contas para a Secretaria. De acordo com o secretário de Educação e Cultura,

Até o fim do meu último ano lá eu nunca fiz mais nada em escola, fazíamos com a comunidade, eles contratavam, pagavam e então prestavam contas para a SEC, é lógico que sempre assessorados pelos técnicos da Secretaria, mas, eu nunca mais fiz concorrência para escola alguma (Admir Ferro).

Todavia, o repasse de verbas não significava que a APM poderia arbitrar livremente sobre sua destinação. Junto ao poder de compra, os membros da APM também recebiam orientações para a utilização dos recursos, em termos de percentual para cada rubrica de despesa. Os valores não utilizados eram devolvidos à SEC, logo

Eles não podiam economizar em algo para gastar com outra coisa, pois, se sobrasse dinheiro tinha que ser devolvido, mas, eles achavam que se economizassem poderiam gastar com outra coisa fora da REBI (Jumara Bulha).

Para o desempenho dessa atribuição, a coordenação da REBI incluía os pais em discussões sobre a qualidade do espaço físico - da construção arquitetônica ao mobiliário e equipamentos - pois, frequentemente, os pais manifestavam-se contrariamente a determinados investimentos e itens para as bibliotecas. Em muitas situações, eles não entendiam porque

\footnotetext{
${ }^{41}$ A Profa. Cibele Haddad Taralli, docente da Faculdade de Arquitetura e Urbanismo (FAU) da USP, foi responsável pela concepção arquitetônica do projeto.
} 
gastar "tanto dinheiro" com uma cadeira se há outras mais baratas: "Afinal, não é tudo a mesma coisa?".

Contornar essas situações implicou estabelecer um mecanismo permanente de negociações junto a SBE, cuja finalidade era explicitar as razões e argumentar sobre a importância de determinados itens, pois os integrantes da APM

Precisavam concordar com aquilo que estava sendo encaminhado (Jumara Bulha).

Tais negociações enveredavam sobre o papel da biblioteca na educação dos alunos, assim como sobre o significado de cada elemento para o alcance dos objetivos propostos, muito mais sérios que meras questões estéticas. Acerca deste processo foi relatado que

A APM recebia uma cartilha com o que eles tinham que comprar e, às vezes, eles não queriam comprar aquilo, porque achavam que a escola precisava de outra coisa. Então eles se mobilizavam e iam conversar conosco. O professor Edmir chegou a fazer muitas assessorias para os pais explicando, por exemplo, porquê comprar determinada cadeira e não outra. Isto porque as cadeiras que compravámos eram caras, era uma cadeira importada e os pais não se conformavam em gastar tanto dinheiro em cadeira sendo que poderiam comprar cadeiras mais baratas e investir dinheiro em outras coisas. Então foi difícil, tivemos que conversar muito com os pais para que comprassem a cadeira que estávamos orientando (Jumara Bulha).

O modelo de repasse de verbas para a APM refletiu na apropriação do teor implicado no desenvolvimento das bibliotecas escolares, em São Bernardo do Campo. Nesse sentido, a fala da chefe da Divisão de Programas Educacionais da SEC é bastante elucidativa:

O dinheiro estava vinculado às questões teóricas, às questões de aprendizagem. Quando você traz o pai para discutir onde investir o dinheiro da escola, por exemplo, "ah, mas esse tanto em cadeira?" Mas aí discutia-se com ele que "essa cadeira faz com que a pessoa fique sentada, goste de ficar, queira ler mais, tem um intenção por detrás dela”. Este processo é formativo, o pai passa a ter outro olhar sobre o que a escola trabalha, é isso que é rico. E essa discussão o Programa desencadeava com a comunidade (Jumara Bulha).

A gestão partilhada de recursos acabou sendo estratégia importante para aproximar a comunidade das decisões relativas à administração da escola e, portanto, ao desenvolvimento 
das bibliotecas. O modelo destacou a necessidade de que a escola seja, de fato, objeto de construção coletiva e, também, da criação de mecanismos que estimulem a comunidade a participar das decisões que afetam a escola. Nesses termos, sobressaiu a extrema importância de que os beneficiários das políticas públicas, crescentemente, tornem-se sujeitos e não meros objetos da ação pública (CAETANO, 2007 apud OLIVEIRA, 2010).

\subsection{Permanência da Política Pública}

A implementação da REBI demandou uma série de elementos, como a proposição de novos meios de ação e acompanhamento permanente do seu desenvolvimento, formação continuada, troca de experiências entre os sujeitos envolvidos, investimentos financeiros, criação de novos cargos na estrutura administrativa da SEC, fundamentais para a obtenção de resultados positivos no âmbito das bibliotecas escolares.

A consolidação e permanência dos investimentos na política pública demandaria o reconhecimento, dos gestores, acerca da importância de todos os seus elementos constitutivos, para o alcance dos resultados desejados. Na experiência em foco, distintos fatores impactaram nos rumos da ação, que sofreu com a carência de clareza quanto à sua complexidade.

\subsubsection{Avaliação}

Se, por um lado, a avaliação "é imprescindível para o desenvolvimento e a adaptação contínua das formas e instrumentos de ação pública" (FREY, 2000, p. 229), por outro, é a delimitação dos critérios avaliativos que irá determinar aquilo que será constatado.

Na REBI, as avaliações eram internas e consistiam em questionários elaborados pela própria SBE para serem respondidos pelos profissionais das escolas. Conforme relato,

Internamente tínhamos uma estrutura na Secretaria. Todo ano tinha um caderno de metas, havia as metas da Secretaria, do Departamento $e$, geralmente, havia uma meta de biblioteca escolar e todas as escolas avaliavam. Esse caderno era avaliado por todas as escolas, isso era feito numa reunião dentro da escola, eles pegavam o caderno 
e iam avaliando. A formação sobre biblioteca, quantas pessoas participaram, foi boa, etc... Tinha essas perguntas e aí vinha essa avaliação. Só que era interno, era nossa avaliação, nós fazíamos as perguntas. Era um olhar mais superficial mesmo, mas, a gente tinha e isso começou a ser construído pela equipe. Começou como uma coisa simples, algumas folhinhas e metas e transformou-se num grande caderno em que tudo era avaliado. Essa foi outra proposta, que se mostrou efetiva até pra replanejar para o ano seguinte (Dalva Franceschetti).

O depoimento indica que a própria SBE, imersa no processo, era quem avaliava e, portanto, definia as categorias a serem analisadas. Enquanto isso, a partir do questionamento apresentado, os próprios educadores encarregavam-se de avaliar a BEI. Podemos dizer então, que importantes dimensões talvez tenham escapado aos profissionais envolvidos diretamente no processo; dimensões que um olhar estrangeiro sobre a política pública poderia captar, extrapolando os limites daqueles que estavam imersos $n a$ ação política. Por questões de foco, muitas vezes, aqueles que estão diretamente envolvidos com a implantação da política pública podem, em certos momentos, ter seu olhar voltado a microdimensões, a questões que estão em evidência, perdendo de vista outros elementos fundamentais, que podem acabar silenciados. Do mesmo modo, é importante que a avaliação comporte diferentes olhares sobre o mesmo objeto.

Dalva Franceschetti admitiu essa carência no processo:

A gente não teve nesse período, e a gente sentiu muito, alguém que viesse avaliar esse processo de fora. Acho que precisava da universidade fazendo essa avaliação, porque estávamos o tempo todo tentando implantar, tentando formar, e imersos no processo. Tem que ser um olhar estrangeiro para poder fazer (Dalva Franceschetti).

Revela-se, com isso, a complexidade implicada nos processo de avaliação, pois, muitas vezes, falham por estarem centrados na verificação do cumprimento de um plano e na análise de objetivos, supondo que o plano e os objetivos conquistados já tenham um valor reconhecido por todos (MOKATE, 2002). Justamente nesse âmbito a avaliação da REBI apresentou fraturas, na medida em que o 'valor' ou 'mérito' da biblioteca escolar ainda não era, efetivamente, compreendido em toda a sua amplitude. Isso considerado, o reconhecimento da relevância de todos os elementos constitutivos da política pública foi prejudicado, contribuindo para mudança de rumos na ação política. 


\subsubsection{Consolidação de Ações e Investimentos}

Relatos demonstraram que a política pública de bibliotecas escolares sofreu abalos ainda na gestão que a havia implantado. A expansão da Rede foi acompanhada por dificuldades para que a qualidade das ações em desenvolvimento fosse mantida, sobretudo em termos de verbas, em geral escassas, dada a concorrência de novas prioridades públicas. Conforme afirmado,

Foram surgindo outros projetos nas escolas, laboratório de informática, ateliê e não sei mais o quê. [...] "nós estamos investindo em muitas coisas, corais, etc.". Quer dizer, a REBI tinha uma expressão, era uma rede importante, mas, não era mais novidade. Então você ficava negociando e aí tínhamos as grandes brigas de continuar com estrutura, com formação. Era ficar mordendo os pedacinhos pra você não perder, segurar nos dentes o que você já tinha conquistado e tentar abocanhar mais um pouquinho (Dalva Franceschetti).

As dinâmicas das políticas públicas, de fato, são perversas e podem acabar com um investimento importante, em razão das prioridades escolhidas a partir do jogo de forças em cada gestão. A determinação da redução de investimentos para a manutenção das ações sinalizava que, a partir de determinado momento, o foco seria outro; as bibliotecas escolares entrariam em diferente esfera de demanda.

Para uma entrevistada, a situação inscreveu-se na

Falta de entendimento da validade desse projeto em sua integridade pelo governo que administrava. Eu ouvia na fala do Maurício Soares, que foi o prefeito, 'porque as BEIs são bibliotecas com computador, criança pode usar computador'. Era uma visão limitada do conceito, é óbvio que a equipe do Edmir tinha visão muito mais ampla que eles não conseguiam entender (Cláudia Sarro).

De um lado, a representação dos motivos que levaram à mudança de ênfase sobre as bibliotecas é correta, na medida em que o gestor público, por mais informado que seja, nem sempre consegue avaliar o alcance e dimensão das políticas públicas de sua gestão. De outro, porém, é necessário ter claro que o jogo de forças sociais, políticas, econômicas e culturais que gravita no universo das políticas públicas é capaz de alterar situações, sem prévio aviso, 
colocando em risco investimentos e resultados de toda ordem, mesmo se estes são significativos aos contextos em que se inserem.

Apesar do reconhecimento da importância da REBI - demonstrado pelos investimentos realizados ao longo da gestão - com o tempo, até mesmo o papel das PABEs passava a ser questionado. A figura da PABE foi um constante ponto de tensão, na medida em que esta profissional havia passado por uma seleção interna para trabalhar na BEI e deixou de atuar diretamente na sala de aula; em seu lugar, foram postos professores substitutos. Conforme relato,

Então tínhamos uma tensão com a área de ensino por conta dos profissionais (Dalva Franceschetti).

Com o crescimento da Rede - e consequente aumento no número de PABEs -, a tensão se acentuou,

Já estava com mais de sessenta professores fora da sala de aula para atuar na biblioteca, e aí começou "porque se o professor sai da sala de aula tem que ter outra pessoa na sala dele”. Quando começou a tomar volume a REBI, criou-se um outro problema de funcionário na Secretaria e aí começaram discussões homéricas. Essa tensão foi se intensificando conforme a Rede foi crescendo "vocês estão tirando professor da sala da aula para por na biblioteca, como fica isso?" e isso foi gerando um clima de tensão mesmo (Dalva Franceschetti).

Em meio às discussões sobre recursos humanos, a administração municipal chegou a cogitar a retirada da PABE das bibliotecas - ação posteriormente confirmada, acreditando que os próprios professores da sala de aula poderiam, sem auxílio, desenvolver atividades com seus alunos nas BEIs. Todavia, as negociações empreendidas pela SBE garantiram a continuidade da figura da PABE na gestão então em curso.

O fato sinaliza para distintas dimensões. De um lado, revelou que a manutenção de uma política pública, tal como a que criou a REBI, não depende exclusivamente do Poder Executivo. Implica uma série de articulações que, por sua vez, podem colocar em causa ações bem sucedidas no passado. Por outro, indicou que a biblioteca escolar não era questão pública indiscutível para os profissionais da educação, pois

Havia falta de entendimento. "Eu tenho uma rotina de escola, meu negócio é aprendizagem dos alunos, é sala de aula”. Mudar isso e dizer que os alunos não estavam perdendo tempo indo para a 
biblioteca, que isso não estava sendo um 'enfeitinho' na vida deles, esse era o grande nó (Dalva Franceschetti).

Aliado à incompreensão da importância da biblioteca na educação, estava a incompreensão, por parte dos educadores, do papel do educador na biblioteca. Com isso, destacou-se que a luta entre forças sociais deve ser considerada pela política pública, considerando-se que seus resultados podem manifestar-se a médio e longo prazo.

O momento também acenou para fraturas na ampliação da REBI, pois a ação política não considerou a necessidade de contratar profissionais para atuar diretamente nas bibliotecas. A expansão da Rede não foi acompanhada pelo investimento no aumento do número de profissionais contratados, mas, sim, pelo ‘empréstimo' de professores da sala de aula. Se num primeiro momento a medida mostrou-se satisfatória, com o aumento expressivo do número de bibliotecas, revelou-se problemática, indicando a necessidade de investimentos financeiros em recursos humanos.

\subsubsection{Continuidade: a Política Pública Para Além dos Sujeitos}

A alteração na gestão municipal - com a saída do prefeito e também do secretário de Educação e Cultura -, determinou profundas modificações na política pública. A nova administração decretou o término das ações que vinham sendo desenvolvidas:

Quando mudou a gestão tudo acabou, porque a gestão que entrou entendeu que era um programa de outro governo. Apesar de a gente ter deixado tudo, deste trabalho já estar fisicamente implantado nas escolas, houve um rompimento de estrutura (Jumara Bulha).

Nesse sentido, embora a estrutura física, já consolidada, tenha sido mantida, as atividades em curso sofreram alterações, que acabaram por dispersar os investimentos feitos ao longo de anos para estruturar uma dinâmica de trabalho em rede. As mudanças remetem para a fala de uma das entrevistadas, que acredita que a REBI

Foi uma política de biblioteca diferenciada no Brasil, isso deu muita visibilidade. Então quando entra a nova administração ela precisa dar uma apagada, uma ofuscada (Dalva Franceschetti).

Ainda conforme outra entrevistada, 
Acho que isso é um problema da gestão pública, a questão da memória. Vejo, assim, quando você muda de gestão quer perder a memória, quer apagar, acaba alijando as pessoas que, em tese, participaram na gestão anterior, que participaram de projetos identificados com a gestão anterior. Assim, muita coisa é deixada de lado, então foi muito isso o que aconteceu (Cláudia Sarro).

A descontinuidade de investimentos em projeto identificado com outra gestão, atitude política que não se restringe ao contexto de nossa discussão, traz perdas para a sociedade, na medida em que as novas administrações, por vezes, simplesmente se recusam a admitir o potencial de determinadas políticas por terem sido desenvolvidas por outra gestão.

O término da parceria com a universidade e mudanças no quadro de profissionais que estavam à frente da SBE deixaram, de certa forma, a Rede acéfala, uma vez que os sujeitos com conhecimento sobre o dispositivo, não mais atuavam na Seção. Os novos profissionais chamados a gerenciar a REBI, por mais que se esforçassem, não dispunham da experiência profissional construída ao longo do período inicial, que durou nove anos e propiciou a apropriação do conceito de biblioteca escolar adotado, com acompanhamento presencial da universidade.

Nessa perspectiva, os novos rumos apresentaram-se como uma escolha política que, por um lado, pode evidenciar a simples opção por ofuscar os feitos de outra gestão, mas, por outro, pode revelar o desconhecimento do político acerca da importância das ações que vinham sendo desenvolvidas.

No novo cenário, embora tenha havido focos de resistência, pois

Muitas escolas foram solidárias, porque entendiam aonde a PABE contribuía realmente [...] a nova gestão determinou o término da figura da PABE (Dalva Franceschetti).

Estas profissionais voltaram para a sala de aula, a partir de decisão que ia ao encontro do discurso da campanha política, que afirmava

"Nós vamos mandar todos os professores para a sala de aula, está errado biblioteca ter professor". Então foi usado politicamente nesse sentido (Dalva Franceschetti).

A retirada das PABEs da biblioteca, substituídas por agentes de biblioteca e alguns bibliotecários, foi sinalizada como uma das grandes perdas da REBI. 
Pois, à medida que você não tem mais essas pessoas, você simplesmente teve um espaço. Um serviço de catalogação de acervo, uma visão técnica do processo e não também pedagógica e cultural. Foi uma perda, acho que aí o projeto começou a ser desmontado, a ser entendido como uma biblioteca que tem o material, tem alguém que faz o empréstimo e tal, mas não tem uma ação pensada, pedagógica, uma ação mediadora (Cláudia Sarro).

Para o secretário de Educação e Cultura, a atitude política também se revelou problemática:

É um prejuízo enorme essa mudança de política para a biblioteca, até porque não fiz isso da minha cabeça, isso foi muito discutido em parceria com a ECA, eles mesmos defendiam que tinha que ter professor na biblioteca, pois era uma extensão da sala de aula. Do jeito que ficou hoje é uma biblioteca que você vai lá consultar, eu só posso entender que há um prejuízo grande no aprendizado das crianças (Admir Ferro).

Os novos rumos indicam que a consolidação de uma política pública de bibliotecas escolares, em face de sua complexidade e indispensável acúmulo, tendo em vista resultados a médio e longo prazo, implica continuidades, ainda que reformulações sejam desejáveis e indispensáveis.

No quadro de transformações está a incompreensão acerca do papel da biblioteca escolar, pois, embora a ação política inicial tenha sido direcionada para sua ressignificação, é certo que a empreitada demandava investimentos de longo prazo para a obtenção de resultados em ampla escala. Conforme afirmou Cristina Bisognini, sobre os resultados alcançados,

Não foi $100 \%$, porque a história que a gente traz de biblioteca é uma história de um espaço passivo, então chegar e entender, depois de décadas de vida, ou, então por nunca ter lido um livro ou não ter passado por uma experiência em relação à leitura, à criação ou criticidade, então como é que se faz? A pessoa não consegue sair daquele patamar ali. Então algumas pessoas não conseguiram entender a biblioteca interativa e a proposta. Esses não conseguiram avançar porque continuaram com aquele lugar comum da biblioteca passiva, não se viam também como sujeitos capazes de alterar uma informação ou experimentar aquela informação. Não existe algo $100 \%$, lá não foi 100\% (Cristina Bisognini). 
Em meio ao cenário de mudanças é preciso considerar que a ação política era limitada a um contexto específico: as escolas. Logo, embora a prefeitura tenha se ocupado em divulgar o empreendimento, o contato com as bibliotecas era restrito a determinadas parcelas da população: profissionais da educação, alunos e seus pais. As rupturas, portanto, não foram reconhecidas por amplas parcelas da população. Muito provavelmente, até mesmo para os pais, de imediato, esta alteração nem tenha sido sentida, visto que as bibliotecas permaneciam instaladas nas escolas. Ou seja, as perdas no âmbito das práticas pedagógicas e culturais das bibliotecas não foram imediatamente sentidas por todos. Todavia, o correr do tempo demonstrou que a eliminação da figura da PABE trouxe perdas para o processo de ensino, pois

Se você conversar hoje com as escolas, independente da linha política que a escola ou diretor tem, você vai sentir na fala deles, da maioria da rede, a perda que eles sentiram da saída dessa figura, porque era uma coisa muito estruturada (Dalva Franceschetti).

Há, portanto, que se pensar no significado da eliminação das PABEs e seus reflexos na ressignificação da biblioteca escolar. A Professora de Apoio a Biblioteca Escolar, categoria nova no quadro das BEIs, parece ter conferido identidade a um grupo profissional e à própria biblioteca, que não era mais um espaço exclusivo das coleções, mas, sim, de relações, de diálogo entre os sujeitos e a informação. A superação de paradigmas demandaria a continuidade de ações persistentes, envolvendo professores, diretores, e outros profissionais que atuam diretamente na biblioteca, além de alunos, pais e comunidade em geral.

O percurso, que contou com a participação de profissionais combativos, também foi marcado por entraves, fomentados a partir de mentalidades que se mantiveram na defensiva, aguardando a administração passar. Nesses termos, a política pública, com ênfase na obrigatoriedade de que todas as escolas tivessem bibliotecas e também em programas efetivos - acompanhados e avaliados - perdeu forças.

A decisão por implantar bibliotecas nas escolas, independentemente de posicionamentos contrários, foi necessária para que todos os alunos tivessem direito à biblioteca. Ademais, a estratégia ia ao encontro do momento político favorável, assim, a SBE aproveitou para criar o maior número possível de bibliotecas:

A gente teve uma angústia muito grande em garantir a implantação dos espaços porque ele fazia parte do processo, a gente não largou em momento algum a questão do conceito, mas era muito difícil 
lidarmos com essas duas coisas com o tamanho da equipe (Dalva Franceschetti).

A preocupação garantiu, portanto, a existência de bibliotecas nas escolas, independentemente de mudanças na esfera de poder. A agilidade mostrou-se importante, pois caso não tivessem sido desenvolvidas BEIs em todas as escolas, a nova gestão poderia decidir interromper investimentos. Mas, por outro lado, a urgência das ações contrastou com o tempo de apropriação de cada sujeito que atuava na escola. Para a gestora da SBE, isto pode ter contribuído para que não houvesse maiores resistências quando a nova gestão municipal determinou mudanças no projeto. De acordo com Dalva Franceschetti,

Como foi tudo muito imposto, então alguns se posicionaram "agora a gente não quer, agora a gente fecha” (Dalva Franceschetti).

E assim, prossegue

A maior lição que aprendi é que por mais ansiedade que tenhamos essa apropriação, esse tempo de apropriação ele é longo e você tem que ter paciência, cada um se apropria no seu tempo. Você tem que dar subsídios, sua atenção, os conceitos, mas, a apropriação só vai acontecer na hora que a pessoa der um 'click', que aquilo fizer sentido. Tem que tentar achar esse clique, não é falar numa palestra, dar um curso, falar uma vez e pronto, está dado...não...é tempo...É tempo para as pessoas sentirem realmente uma diferença, um modo de pensar, de fazer diferente. Então, assim, por mais ansiedade que a gente tenha tido, as pessoas tinham que se apropriar, porque uma vez apropriado você não tira mais (Dalva Franceschetti).

Diante disto, a política pública foi remodelada, rompendo com o conceito de biblioteca escolar sob o paradigma da apropriação cultural, para o qual as práticas pedagógicas e culturais eram centrais. A experiência é precisa em demonstrar que não são ações empreendidas em uma década que irão transformar um cenário problemático, permeado por mentalidades construídas ao longo de séculos de nossa história, que conformou a biblioteca escolar como dispositivo voltado à transmissão do saber. 


\subsubsection{Manutenção da Política Pública: o Diálogo Não Pode Parar}

No atual cenário, embora a estrutura física das bibliotecas tenha sido mantida, o cerne da política pública inicialmente desenvolvida, foi modificado, pois uma nova concepção direcionou as ações em torno das bibliotecas escolares, concentradas na manutenção de espaços físicos e recursos informacionais. De acordo com relato,

Acredito que hoje a administração tem uma visão tecnicista das bibliotecas, tanto é tecnicista que a equipe que está lá é basicamente técnica, não tem discussão conceitual, visão conceitual do papel da biblioteca, de sua importância para alavancar o processo educativo, o processo do conhecimento, de autonomia. Isso conceitualmente todo mundo diz, mas, a forma como está organizado não permite que isso se efetive lá na ponta, porque é uma concepção que você precisa mudar durante anos. Essa é minha percepção da realidade (Cláudia Sarro).

Em meio ao novo enfoque, a própria noção de trabalho em rede mostrou-se esgarçada, com a ruptura da busca do diálogo permanente e ações articuladas entre sala de aula profissional da BEI-SBE.

Nesse contexto, o espaço físico também foi afetado, tendo sido constatado em uma das BEIs que até mesmo as cores inicialmente utilizadas no piso e nas paredes, selecionadas a partir de critérios que objetivavam promover a sensação de acolhimento, foram alteradas. A modificação, determinada pela própria escola, se insere num quadro em que prevaleceu a carência de diálogo e o desconhecimento de que o espaço da biblioteca não é um mero suporte, mas também um definidor das relações. Nesse sentido, os matizes que objetivavam acolher crianças e jovens na biblioteca foram substituídos pela frieza de outros tons. 


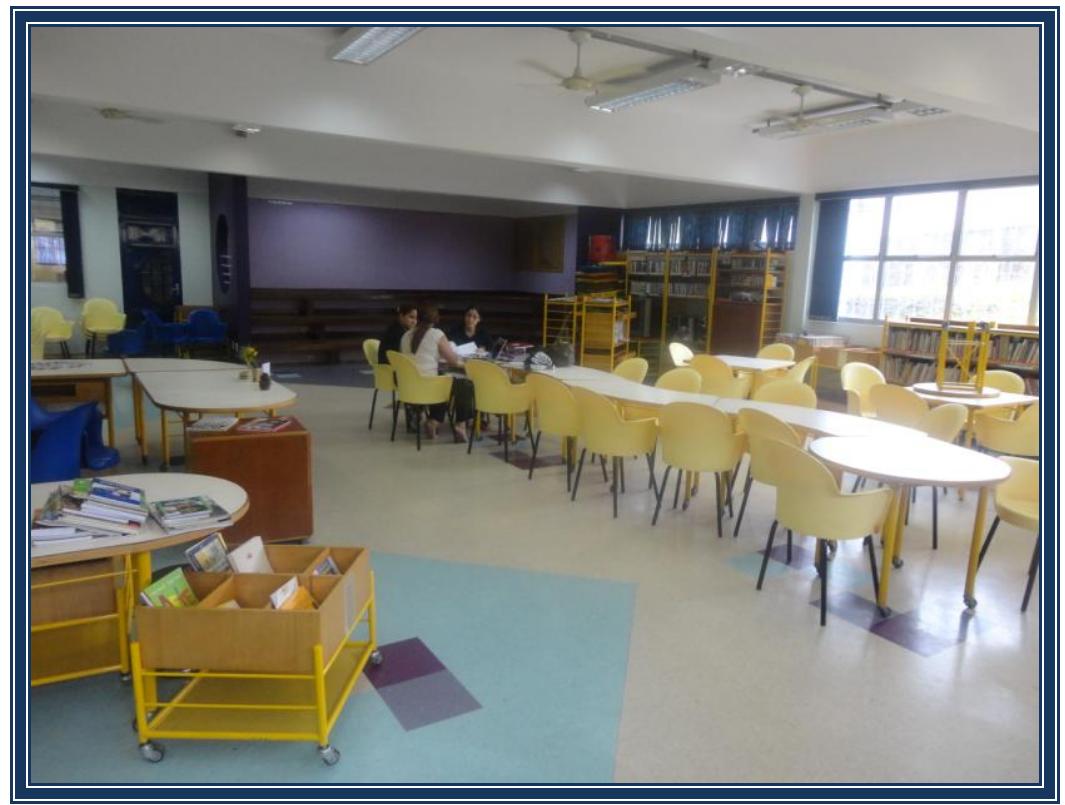

Fotografia 4: BEI Gente Feliz. Escola Erminia Paggi. (Fonte: Acervo da Escola Erminia Paggi)

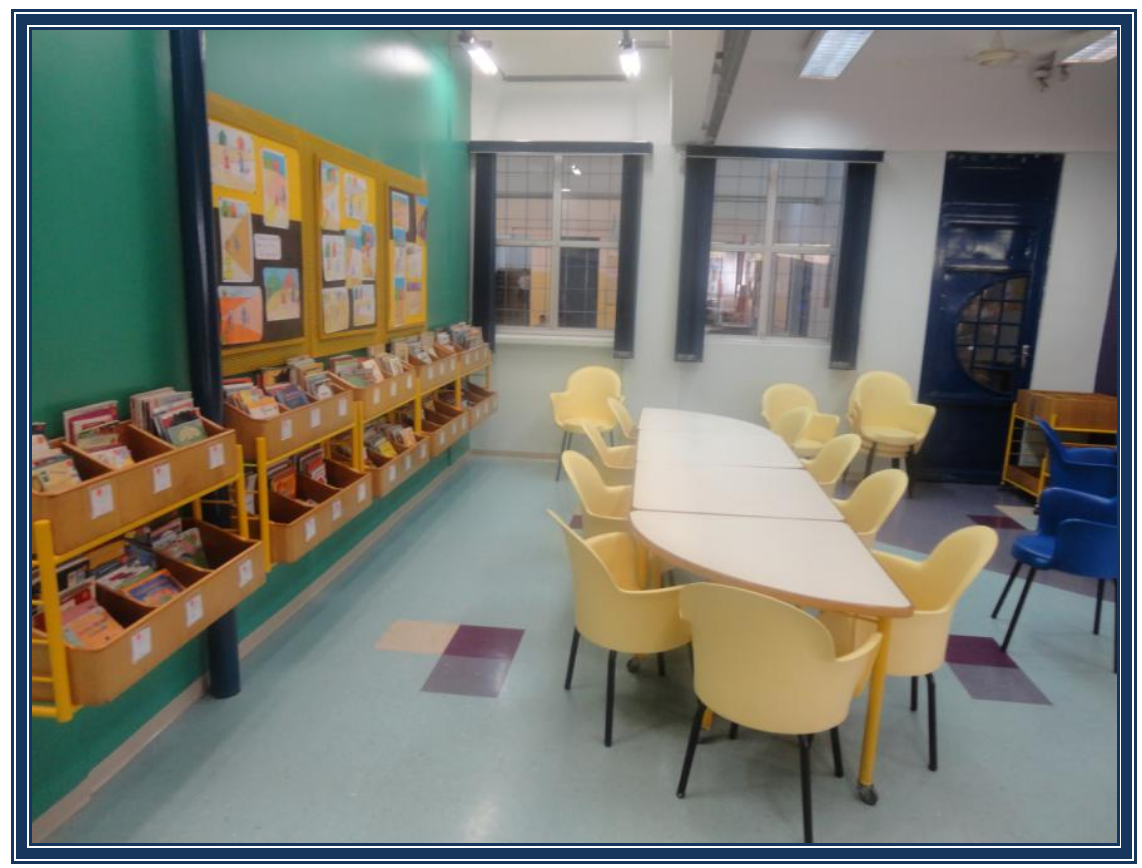

Fotografia 5: BEI Gente Feliz. Escola Erminia Paggi. (Fonte: Acervo da Escola Erminia Paggi)

Apesar das perdas decorrentes das descontinuidades, a criação de uma rede física de bibliotecas gerou um fato: a contingência dos equipamentos. Que destino dar a eles, já que são evidências de uma ação política? Quanto a isso, após certo tempo as bibliotecas escolares beneficiaram-se dos vestígios do período em que ganharam relevância e ênfase nas políticas públicas municipais.

Conforme afirmado por Perrotti, 
Eles [a SEC] estavam em busca de solução, de caminho para um problema. "Está bom, nós precisamos de biblioteca" eles reconheceram, só que "nós estamos sem professores na sala de aula, falta professor na sala de aula, o que fazemos diante dessa questão?" (Prof. Dr. Edmir Perrotti).

A partir desta busca firmou-se, em 2011, nova parceria entre pesquisadores do ColaborI- ECA-USP e a Prefeitura de São Bernardo do Campo, tendo em vista realizar o Programa Biblioteca e Educação (PBE) que, diante das condições do terreno, propunha como alternativa a regionalização das BEIs, que se articulariam em núcleos, de acordo com sua distribuição geográfica na cidade. Cada Núcleo seria 'supervisionado' por um bibliotecário da REBI, em estreito contato com os auxiliares e agentes de biblioteca das demais BEIs, assim, o PBE resgatou a importância do diálogo entre os profissionais, buscando reestabelecer as conexões da Rede. Também se concentrou na relevância da formação, com o intuito de incluir os profissionais da REBI na retomada da política de bibliotecas escolares do município, considerando o potencial das BEIs e a capacidade crítica e criativa de seus quadros.

As ações perduraram ao longo de dois anos (2011-2012), tempo insuficiente para que transformações mais amplas ocorressem. O terreno, desta vez, apresentava nova configuração, sendo que muitos dos profissionais nunca haviam tido contato com bibliotecas e, muito menos passado por alguma formação para trabalhar nestes dispositivos, exceto, obviamente, os poucos bibliotecários que integravam a Rede.

Nesse sentido, a fala de Perrotti é esclarecedora

A ideia de apropriação, ela não termina. Agora, portanto, me parece que romper o terreno com a universidade, a universidade com o terreno, isto me parece realmente estar inviabilizando um projeto de apropriação (Prof. Dr. Edmir Perrotti).

Diante disto, não está em questão a ruptura de um contrato formal entre campo político e campo científico. Não se trata de afirmar que uma política pública precisa comportar eternos vínculos do terreno com o campo científico; a questão em causa é, sobretudo, a ruptura com uma concepção de biblioteca escolar, construída pela acumulação de referenciais da teoria e da prática. A partir disso, Perrotti afirma que

O problema inicial não foi solucionado, resolvido, o que quer dizer que aquele formato da PABE, ele continua, me parece, sendo posto em questão lá. O conflito está dado e não tem resposta para ele me 
parece, porque, assim, "faltou professor na sala, não vai poder mandar o professor para a biblioteca e também não tem bibliotecário para tudo isso". Enfim, tem um nó, quer queira ou não, você precisa ter recurso e o mais importante que é recurso humano, e isso custa (Prof. Dr. Edmir Perrotti).

A situação indica que investimentos em recursos humanos não podem se resumir à contratação de profissionais, orientados a abrir a biblioteca e realizar empréstimos. Uma atuação alinhada com concepções inovadoras demanda, não só profissionais com saberes específicos, mas, também, formação continuada, reunindo teoria e prática, elemento que se sobressai como categoria fundamental à consolidação de políticas públicas para bibliotecas escolares que não se limitem à oferta de acervos.

A problemática não se restringe à experiência em discussão, mas é marca de nossa realidade, ainda permeada por indefinições quanto ao papel da biblioteca escolar e do profissional que nela atua. Tais incertezas não estão circunscritas ao terreno, mas permeiam as universidades, ainda cambaleantes na tarefa de propor currículos para formar profissionais e no reconhecimento da relevância de uma perspectiva transdisciplinar. Para Perrotti, a questão da profissionalização

É um nó que mesmo a universidade continua enfrentando. Quer dizer, como vamos formar esses profissionais para essa realidade é um nó que os Conselhos vêm enfrentando e que é a realidade, portanto. É só olhar os países mais desenvolvidos, o bibliotecário como um gestor de rede tem coisas a fazer de gestão que ele não pode dar conta disso e ainda virar pedagogo. Primeiro porque ele próprio não tem formação, segundo porque é tal o volume de coisas novas a serem feitas, porque antes ele era um simples organizador, hoje tem que organizar e se comunicar, então é um comunicador. Dentro de uma rede tem que ser comunicador. Bem, então preciso de outro profissional que é esse mediador, que tenha conhecimento sobre usos de sistema de informação, mas, não é o produtor do sistema de informação, ele é um mediador. São dois perfis duas categorias de profissional, um que é gestor de sistema de informação e um que é mediador (Prof. Dr. Edmir Perrotti).

A fala mostra que as políticas para bibliotecas escolares em nosso país terão que enfrentar uma nova questão, a saber, a própria identidade dos profissionais que nelas atuam. Quem são eles? Quantos serão necessários para cobrir a extensão do território nacional? 
Que formação e práticas serão demandadas, para que cumpram o desafio da quantidade e da qualidade indispensáveis a consolidação das bibliotecas?

O emaranhado de questões suscitadas pela REBI aponta para uma rede de elementos envolvidos na proposição de políticas públicas para bibliotecas escolares, dentre os quais a criação de espaços físicos é apenas um dos itens a serem considerados. E certamente não é o mais complexo, face ao desafio da renovação de princípios e práticas para bibliotecas escolares, em meio à conjuntura em que se inscreve: a desigual sociedade brasileira, dominada por uma educação voltada à reprodução de conteúdos, num contexto de excesso informacional, no qual são subtraídas condições de "participação nos processos de definição das significações sociais mais amplas" (PERROTTI, 2009, p.13). 


\section{CONSIDERAÇÕES FINAIS: POR UMA NOVA BIBLIOTECA ESCOLAR...}

Esta pesquisa partiu de uma inquietação em face de um problema social concreto: a carência de bibliotecas escolares em nosso país, aliada ao surgimento de texto legislativo que determina a obrigatoriedade de sua criação nas instituições de ensino brasileiras, buscando assegurá-las como um direito social. A esta trama somam-se outros elementos, explicitando um contexto certamente problemático. Dentre eles, o hiato existente entre a biblioteca escolar e a sociedade que, de forma geral, não encara tal ausência como um problema público. A falta de vínculos é, ainda, marca de nossa história, em que a biblioteca escolar desenvolveu-se precariamente, com amarras conceituais que a definiram, sobretudo, como coleção de recursos informacionais, voltada a preservar e transmitir a dita cultura de elite. A conceituação, a partir de apenas uma de suas características, predomina na atualidade e determinou a inscrição da biblioteca escolar na legislação brasileira, exclusivamente, como um acervo organizado de recursos informacionais. Ou seja, para atender à disposição legal são suficientes ações centradas na garantia do acesso à coleção por ela disponibilizada.

Diante desta conjuntura, e certas de que "a denúncia do presente [...] não é suficiente para definir uma ação possível e um futuro aceitável” (TOURAINE, 1996, p.192), lançamonos em discussões tendo em vista a urgência de iniciativas que ressignifiquem a biblioteca na educação, como dispositivo voltado a garantir o direito de saber informar-se, de apropriar-se de informação e cultura. Direito este já apontado por Chauí (1989) como indispensável à democracia, na medida em que cria possibilidades para que os sujeitos atuem como produtores do saber e não somente como consumidores passivos de informação.

Para a conquista de um novo e essencial papel para a biblioteca na educação, a política pública apresenta-se como caminho e, assim, fizemos um percurso em meio à teoria e à prática, trazendo à tona a complexidade implicada em uma ação política para bibliotecas escolares. Complexa porque a definição do conceito de dispositivo informacional que deve alimentá-la, rumo aos princípios educativos contemporâneos, nem sempre se mostra devidamente clara ou adequada ao conjunto de atores diretamente implicados em sua implantação e desenvolvimento, sem perder de vista, ainda, as especificidades do multifário cenário nacional. 
A abordagem de um contexto concreto - com suas nuances, contornos e resistências nos permitiu observar a agudeza das ações imersas nas dinâmicas vivas do fazer político, as quais, combinadas a referências buscadas na literatura geral sobre o tema, permitiram identificar parâmetros, sem descarná-los das forças que regem as relações humanas e sociais. A combinação desses dois eixos, portanto, foi fundamental para a compreensão e identificação das parábolas que traçam possíveis caminhos à redefinição das bibliotecas escolares, nas condições brasileiras.

Nessa conjuntura, conforme nos alerta De Certeau (1995, p.214), “a política não garante a felicidade nem confere significado às coisas. Ela cria ou recusa condições de possibilidades. Interdita ou permite: torna possível ou impossível”. Assim, conhecer seus desvãos mostrou-se fundamental à percepção de implicações que estão na base de processos de circulação e apropriação da informação na contemporaneidade, nos quais os dispositivos de informação têm papel relevante.

As categorias abaixo elencadas mostraram-se prioritárias no estudo em questão:

A vontade política apresenta-se como categoria essencial às políticas para bibliotecas escolares. Gestores políticos têm papel de destaque na determinação de quais problemas serão alvo de ações e, do mesmo modo, decidem a estratégia que será posta em prática para a implantação de bibliotecas escolares. A ação da classe política em exercício, embasada pela vontade construtiva, é deflagradora de iniciativas, mas, também, fundamental para garantir a continuidade de investimentos e propósitos, indispensáveis à manutenção dos processos em causa. O desejo por mudanças, alinhado à certeza da importância da ação, à compreensão de sua complexidade e, também, à capacidade de avaliação do fator tempo - para surgimento dos primeiros resultados -, caracterizam e constituem elementos que contribuem para assegurar a permanência de processos implicados na política pública. Garantia esta essencial, para que a ação sobreponha-se aos inevitáveis revezes e críticas, produzidos por interesses contrários ou pela ignorância quanto à validade da política, que precisam ser neutralizados, ou ao menos minimizados, nos contextos da ação e decisão.

O protagonismo profissional mostrou-se fundamental à criação e execução de ações inovadoras em torno de bibliotecas escolares. Profissionais que colocam em prática a decisão política, quando inseridos no processo como sujeitos, não apenas reconhecem a importância de seu esforço para a transformação de um cenário problemático, como criam oportunidades diferenciadas para transformá-lo. Nesse sentido, está implicado o que Nogueira (2004, p.62) 
caracterizou como "generosidade individual construtiva", possível a partir do reconhecimento do valor de uma coletividade. Assim, a política pública irá demandar profissionais sensíveis à questão, que atuem afirmativamente com criatividade e criticidade, compreendendo a importância de seu trabalho para solucionar o problema que é público e, portanto, pertence a todos. Nessa perspectiva, a própria prática profissional passa a ser ressignificada, pois os protagonistas redimensionam seus fazeres, tendo em vista as especificidades demandadas pela política.

Em face disso, a escolha daqueles que irão implantar a política é determinante aos resultados obtidos, pois é a atitude de cada um frente às mais variadas situações encontradas no terreno - e, em geral, adversas - que irá delinear o sucesso da criação e consolidação da biblioteca escolar. Por sua vez, é preciso considerar que o protagonismo profissional está intrinsecamente relacionado à vontade política; pois à realização da vontade inicial - inserida numa esfera macro - são necessários sinais de reconhecimento dos sujeitos que estão na esfera micro, ou seja, nas instâncias administrativas encarregadas de objetivar a vontade política em ações. Tal vínculo é realçado, na medida em que a consonância entre objetivos iniciais e ações no terreno dá sustentação à política pública.

O tempo político, compreendido como período necessário entre a definição das ações e o prazo para a percepção de seus benefícios para a população, mostrou-se importante no processo de consolidação da política pública para bibliotecas escolares. As evidências concretas indicaram que o tempo político pode ser antídoto a ações pontuais, de curta duração e descontínuas, que prejudicam iniciativas significativas em torno da biblioteca escolar em nosso país. Essa natureza de tempo é, assim, categoria constitutiva de uma política pública que demanda estratégias de ação a curto, médio e longo prazo, tendo em vista sua expansão e consolidação, fundamentais aos contextos impostos à biblioteca escolar em nosso país. O tempo de assimilação da proposta política e de suas concepções mostrou-se essencial para produzir adesões dos quadros profissionais de diferentes instâncias, indicando que não somente atuar, mas, atuar a favor de determinados princípios, implica um tempo inerente ao próprio processo de construção do protagonismo profissional, referido anteriormente. Esse tempo inicial, que precedeu ao agir - dedicado a apresentar o objeto da política aos profissionais envolvidos com a questão (gestores, profissionais da biblioteca e da sala de aula) -, contribuiu para que fossem desvendadas a complexidade e relevância do trabalho com as bibliotecas escolares que os sujeitos teriam pela frente, para se entusiasmarem e posicionarem-se frente a ele. 
Da mesma forma, o tempo de apropriação, pode ser considerado permanente, tanto pelas dinâmicas internas à própria política pública, quanto pela transitoriedade dos quadros profissionais e comunidade atendida pelas bibliotecas escolares. A apropriação também demandará ações continuadas para que a política regenere-se, face às transformações que marcam os contextos da Educação e da Informação. Assim, o tempo é categoria implícita da política, permeando abordagens permanentes, que compreendam tanto os sujeitos da ação em especial seus quadros de execução -, quanto ações que confiram qualidade e longevidade a este organismo vivo que é a biblioteca escolar.

O diálogo política e conhecimento desponta como categoria do processo; o desconhecimento que marca a biblioteca escolar acentua ainda mais a relevância desta dimensão, já evidenciada por Kingdon (2003) como fundamental à proposição de soluções ao problema público. A vinculação da política pública com instâncias que, por dever de ofício, dedicam-se a estudar, compreender e buscar soluções a problemas que envolvem a biblioteca escolar, mostrou-se fundamental ao enfrentamento de questões, que historicamente vinham sendo respondidas pelo empirismo dos contextos profissionais. Diagnósticos e soluções que ultrapassaram a dimensão imediata dos fatos e situações do terreno, conforme observado, foram fundamentais ao enfrentamento da complexidade (técnica, política, educacional etc.) que marca o quadro das bibliotecas escolares em nosso país.

Entretanto, se por um lado, o referido diálogo é apontado como relevante, por outro, não se reduz a uma ou a outra esfera. Uma ação desta natureza, entendida como conjunta e que, portanto, conjuga distintos elementos, irá demandar protocolos implícitos e explícitos, para reger o relacionamento entre as partes. Nesse sentido, direitos e deveres de ambas as partes precisam ser claramente definidos, para que as inerentes tensões decorrentes de polos e perspectivas distintas, e por vezes antagônicas, não comprometam irreversivelmente o objetivo público que inspirou o encontro universidade-terreno. Como se viu, a relação de complementaridade entre os dois campos, compreendendo saberes da ação e da teoria nas dinâmicas de desenvolvimento de bibliotecas escolares, foi profícua e indispensável para os resultados da implantação da REBI, em São Bernardo do Campo. Logo, protocolos formais de compromissos, que preservem a identidade de cada segmento e comprometam-nos na busca de resultados, é condição objetiva de sustentação do referido diálogo. De outro lado, há que se observar igualmente que protocolos implícitos - pautados nas relações de respeito entre as partes e à diversidade de enfoques, assim como na inclusão da diferença como vantagem para o desenvolvimento da política pública -, são de extrema importância. Nesse sentido, a relação 
política e conhecimento demanda estas duas dimensões que recobram, por sua vez, a relação entre macro e micro dimensões, que alavancou a implantação da política para bibliotecas escolares.

A visibilidade é categoria inalienável da política pública para bibliotecas escolares. A comunicação das ações realizadas e seus resultados permite revelar benefícios e a satisfação da população. Assim, a visibilidade atende a diferentes aspectos que, no caso das bibliotecas escolares sejam, talvez, ainda mais significativos, face aos contextos e representações que perpassam o imaginário social. Assim, a construção de novas representaçães é questão primordial, embutida na visibilidade da política pública, devendo afetar o desenvolvimento de bibliotecas escolares inovadoras em nosso país, que ultrapassem noções como uma sala com livros, lugar de silêncio, local para levar as crianças para se distraírem, espaço para castigo, ou até mesmo o completo desconhecimento. A reversão de tais imagens, tal como se viu, foi construída por meio de ações que aliaram solução e satisfação da comunidade que, por sua vez, passou a reconhecer um novo papel e importância deste dispositivo. Nesses termos, a política pública, ao considerar a força de uma representação de biblioteca escolar que extrapolou a dimensão funcional, tangenciado a esfera do gosto, dos sentidos, produziu vínculos invisíveis, mas fortes, transformando a biblioteca em objeto de desejo das comunidades escolares, elemento fundamental para consolidá-la na cena escolar.

De outro lado, a visibilidade reforçou a política para bibliotecas como investimento, e não enquanto gasto, protegendo a ação de possíveis posicionamentos que viessem a interrompê-la em momento tão delicado, dentro do processo de expansão e consolidação. Assim, foi de extrema relevância a comunicação das iniciativas para os circuitos relacionados à biblioteca escolar - profissionais da Educação, da Informação, alunos e seus pais -, como benefício social no âmbito da escola e de seus alunos.

Por outro, é valioso que a ação política seja também visível para aqueles que não estão diretamente relacionados à biblioteca escolar e, portanto, não estão expostos à iniciativa como lhe sendo benefício direto. Trata-se assim, de educar a comunidade e incentivar a percepção de que políticas para bibliotecas escolares são benéficas à sociedade como um todo, tal como a educação das populações é indispensável ao equilíbrio social e à convivência comum. $\mathrm{Na}$ perspectiva de visibilidade aqui proposta, não está em causa a prática de propagandear feitos de gestão. Trata-se de enfatizar um aspecto fortemente indicado pela pesquisa e que se refere à importância de medidas que apresentem os resultados da política pública para a sociedade 
em geral, em especial, no caso de bibliotecas escolares, ainda marcadamente envoltas pelo desconhecimento quanto a seu valor e, neste sentido, chamar a atenção para a importância do desenvolvimento de uma cultura de biblioteca escolar em nosso país.

Qualificação dos quadros: a pesquisa revelou a fundamental importância dos profissionais, sob diferentes aspectos. De um lado, as reformulações propostas por políticas públicas que visem intervenções sociais significativas implicam - como implicaram no caso estudado -, na ampliação de estruturas, ou mesmo redefinição de papeis dentre os quadros já existentes. As especificidades da implantação da biblioteca escolar, com a requisição de saberes provenientes dos campos da Informação e Educação, demandaram articulações entre profissionais de ambas as áreas, as quais não são óbvias, nem frequentemente encontradas nos contextos nacionais. Assim, a atuação em rede emergiu como aspecto de destaque para as dinâmicas de trabalho, tendo em vista o diálogo entre as diferentes dimensões compreendidas na constituição da política pública emergente.

Atrelado a essa configuração - e face ao ineditismo administrativo gerado por políticas públicas inovadoras -, a existência de sujeitos ocupados com a gestão de relações, que sejam responsáveis por mediações entre os diferentes participantes da ação, cujas perspectivas e posicionamentos entrarão em relação e, às vezes, em conflito, no momento da implantação da política apresenta-se como categoria a ser contemplada no âmbito da política. Tal dimensão, voltada às negociações, sinaliza para o reconhecimento das possíveis adversidades que surgirão ao longo do processo, prevendo caminhos para sua superação. Nestas circunstâncias, a categoria articula-se ao protagonismo profissional, anteriormente mencionado, na medida em que sujeitos críticos e criativos são essenciais para este trabalho.

A pesquisa revelou, assim, que a formação é categoria indispensável para garantir a apropriação da política pública e seus conteúdos; no caso em análise, dentre outros aspectos essenciais, uma nova concepção de biblioteca escolar. Compreendendo diferentes atores da cena política, educacional e técnica, desde aqueles envolvidos com a gestão e atuação direta nas bibliotecas escolares, até os educadores e a comunidade escolar, a formação dá-se em diferentes modalidades - formais, informais, não-formais. A investigação mostrou que, no contexto em que a ação política se deu, a formação de educadores e gestores das escolas foi imprescindível, pois estes profissionais são promotores de elos entre biblioteca e sala de aula, fundamentais para que a biblioteca escolar extrapole a condição de organismo acessório ao processo de ensino. Educadores que se apropriem da nova concepção terão mais chances de 
compreender a pertinência de práticas educativas articuladas à biblioteca e, assim, de cultivar ações neste sentido. Igualmente indispensável, a formação dos profissionais diretamente envolvidos com a biblioteca escolar é tanto no sentido de fazê-la funcionar, quanto de mostrar e dizer sobre ela, revelando todo o seu potencial. Em quadros em que a biblioteca escolar não é unanimidade, por força de razões histórico-culturais que a determinaram e a definiram como instância residual na educação, "fazer $e$ dizer", conforme visto, são objetivos a serem pretendidos pela formação, que tenha em vista a manutenção da ação política.

A formação continuada em serviço, opção adotada no âmbito da política pública em São Bernardo do Campo, revelou-se pertinente e especialmente efetiva para a implantação das bibliotecas escolares. A formação mostrou-se categoria fundamental à apropriação da política e, também, para a implantação de práticas renovadas, em atendimento ao contexto informacional contemporâneo. Formações, incluindo os saberes da teoria e da ação, mostraram-se bastante positivas, ao trazerem as experiências do contexto vivo das bibliotecas para o centro das reflexões, dado que a complexidade da informação na contemporaneidade já indicada na análise da literatura -, demonstra que a abordagem transdisciplinar da biblioteca é condição de seu desenvolvimento na atualidade. Nessas circunstâncias, diante das especificidades dos variados contextos de implantação das bibliotecas escolares, os saberes específicos e exclusivos da formação acadêmica tornam-se insuficientes.

Instâncias de negociação compõem outra categoria de destaque em uma política pública que busque consolidar o papel da biblioteca na educação. O novo conceito, muito provavelmente, encontrará resistências no terreno em todas as etapas do processo - seja da parte de professores, seja de coordenadores -, em face de concepções predominantes e, por vezes, reducionistas de biblioteca escolar. A abertura dos sujeitos à proposta implicará, de algum modo, que aceitem transformações nas práticas (educativas, informacionais, de gestão, etc.), já que cada segmento contará com a colaboração, mas, também, com a intervenção de um outro elemento, até então inexistente. Por exemplo, a sala de aula passará a contar com um novo dispositivo integrado ao processo de ensino. De certa forma, será demandada uma redefinição de identidades profissionais e, nesse sentido, entrarão em cena desejos e tensões, próprios à inclusão do novo.

Não é somente a entrada da biblioteca na escola que deve ser negociada, mas, o seu papel no processo de ensino, pois mesmo aqueles que inicialmente se mostrem favoráveis a ela, podem não compreender a dimensão de suas práticas. Diante disto, instâncias de 
negociação, constituídas por sujeitos certos do valor da biblioteca na educação, são essenciais, tal como visto na análise. A partir do princípio de que as bibliotecas, e suas respectivas políticas, são elaboradas e implementadas por sujeitos, em territórios profissionais, com identidades e princípios próprios, e que implicam espaços e recursos, sua consolidação irá demandar ações que compreendam a força - vale dizer, razão e emoção - de cada ser. Assim, uma gama de emoções entrará em cena para abrir caminhos à biblioteca escolar ou, então, para tentar fechar as portas ao desenvolvimento de todo o seu potencial; a política pública precisa estar preparada para estas adversidades.

A avaliação é categoria voltada à verificação de resultados e norteadora da renovação de processos e práticas, na medida em que permite conhecer elementos positivos e negativos da ação. Para que a avaliação seja, realmente útil é preciso que seus critérios sejam definidos claramente e busquem conhecer os resultados da ação, face ao problema inicial. O estudo indicou que avaliações que comportem um olhar externo são interessantes, na medida em que aqueles que estão imersos no processo nem sempre conseguirão identificar os diversos elementos que interferiram na ação. De outro lado, conforme já sinalizado por Mokate (2002), é importante considerar a fala dos sujeitos. No caso da biblioteca escolar, está em causa a relevância da voz daqueles diretamente relacionados com os resultados da ação profissionais, alunos e comunidade -, mas também dos gestores. Trata-se, portanto, de além da satisfação, identificar se objetivos públicos, políticos, pedagógicos e técnicos estão sendo atingidos.

A renovação da política relaciona-se intrinsecamente à avaliação, pois seus resultados permitirão o redimensionamento das ações. Medidas para revigorar a política pública serão essenciais, não somente para melhorar processos que se mostrem deficientes, mas também para que a biblioteca escolar acompanhe, em perspectiva crítica e criativa, as transformações que marcam o contexto informacional contemporâneo. Nesse sentido, esta categoria articulase ao diálogo com a pesquisa (teoria e prática), com instâncias potencialmente atentas às mudanças que afetam as relações entre biblioteca escolar, educação e sociedade.

A participação comunitária é categoria fundamental à política pública em perspectiva democrática, fazendo com que as decisões extrapolem os gabinetes políticos e demais instâncias administrativas do Estado. Para tanto, o próprio fazer político precisa ser ressignificado, a partir do princípio de que todos os seres humanos são responsáveis pelo mundo e, portanto, por seu desenvolvimento e mudança. 
Nossa pesquisa evidenciou a importância de que esta dimensão seja fortemente considerada para que os sujeitos criem vínculos efetivos com a biblioteca escolar, fundamentais a sua consolidação. Assim, medidas que caracterizem a biblioteca escolar como um valor social são importantes para que as vinculações com os sujeitos não se rompam.

Nesses termos, o direito de ser cidadão, de participar das decisões coletivas não pode ser abstrato, deve depender da inserção dos sujeitos em 'circunscrições públicas' concretas e, também, de decisões adotadas pelos governantes.

O desafio de ações nesta direção é processo a ser assumido pelas próprias bibliotecas, em consonância com outros organismos sociais. Criar possibilidades para a interferência dos sujeitos nas decisões sobre a biblioteca escolar, de acordo Nogueira (2004), é fundamental para que diferentes desejos e tensões entrem em cena e produzam decisões que interessem e vinculem a todos. Tal perspectiva é essencial, já que os sujeitos não são apenas protagonistas das ações, são, sobretudo, a garantia da consolidação da biblioteca escolar em nossa sociedade, na medida em que seu valor social passar a ser efetivamente construído, a partir de processos conjuntos com o poder público. 


\section{REFERÊNCIAS}

AITH, Fernando. Políticas públicas de Estado e de governo: instrumentos de consolidação do Estado Democrático de Direito e de promoção e proteção dos direitos humanos. In.: BUCCI, M. P. D. Políticas públicas: reflexões sobre o conceito jurídico. São Paulo: Saraiva, 2006. p.217-245.

ALONSO, Cláudia Maria Rodrigues. Biblioteca escolar: um espaço necessário para leitura na escola. 2007. Dissertação (Mestrado em Educação) - Faculdade de Educação, Universidade de São Paulo, 2007.

ARANHA, Maria Lúcia de Arruda. História da educação. São Paulo: Moderna, 1989.

ARAÚJO, Eliany Alvarenga de. A palavra e o silêncio: biblioteca pública e Estado autoritário no Brasil. João Pessoa: UFPB, 2002.

ARENDT, Hannah. Entre o passado e o futuro. São Paulo: Perspectiva, 2005. (Debates. Política, 64).

ARENDT, Hannah. Qué es política? Barcelona: Paidós, 1997.

ASSIS, Wanderlice da Silva. O lugar da biblioteca escolar no discurso da legislação sobre o ensino secundário brasileiro (1838-1968). 2010. Dissertação (Mestrado em Educação) - . Universidade Federal do Mato Grosso do Sul, Campo Grande, 2010.

BOGDAN, Robert; BIKLEN, Sari. Investigação qualitativa em educação: uma introdução à teoria e aos métodos. Porto: Porto editora, 2010.

BRAGANÇA, Aníbal. As políticas públicas para o livro e a leitura no Brasil: O Instituto Nacional do Livro (1937-1967). Matrizes, São Paulo, a. 2, n. 2, p.221-246, primeiro semestre de 2009. Disponível em:

$<$ http://www.matrizes.usp.br/index.php/matrizes/article/view/97/152>. Acesso em 06 jul. 2014.

BRASIL. Lei $\mathrm{n}^{\circ}$ 12.244, de 24 de maio de 2010. Dispõe sobre a universalização das bibliotecas nas instituições de ensino do País. Câmara dos Deputados. Disponível em: <http://www2.camara.leg.br/legin/fed/lei/2010/lei-12244-24-maio-2010-606412publicacaooriginal-127238-pl.html >. Acesso em: 11 jul. 2014.

BRASIL. Lei no 9.394, de 20 de dezembro de 1996. Estabelece as diretrizes e bases da educação nacional. Portal do MEC. Disponível em:

<http://portal.mec.gov.br/arquivos/pdf/ldb.pdf >. Acesso em: 27 jan. 2014.

BRASIL. Projeto de Lei $\mathrm{n}^{\mathrm{o}} 3.549$, de 2000. Dispõe sobre a universalização das bibliotecas escolares e determina outras providências. Câmara dos Deputados. Disponível em: < http://imagem.camara.gov.br/Imagem/d/pdf/DCD15SET2000.pdf\#page=212 >. Acesso em: 11 jul. 2014. 
BRASIL. Senado Federal. Projeto de lei da Câmara $n^{0}$ 28, de 2012. Altera a lei n. 9.394, de 20 de dezembro de 1996 - Lei de Diretrizes e Bases da Educação Nacional, para instituir a obrigatoriedade de criação e manutenção de bibliotecas escolares em todas as instituições públicas de ensino. Portal atividade legislativa. Disponível em: < http://www.senado.gov.br/atividade/materia/detalhes.asp?p_cod_mate=105187 >. Acesso em: 7 mar. 2014.

BRUNER, Jerome S. O processo da educação. São Paulo: Companhia editora nacional, 1968.

BUCCI, Maria Paula Dallari. O conceito de política pública em direito. In.: BUCCI, M. P. D. Políticas públicas: reflexões sobre o conceito jurídico. São Paulo: Saraiva, 2006. p.1-49.

CAHN, Matthew A. The players: institutional and noninstitutional actors in the policy process. In: THEODOULOU, Stella Z.; CAHN, Matthew A. Public policy: the essential readings. New Jersey: Prentice Hall, 1995. p.201-211.

CHAMON, Edna Maria Querido de Oliveira; CHAMON, Marco Antonio. sobre o uso da entrevista nos estudos de representação social. In: JORNADA INTERNACIONAL E CONFERÊNCIA SOBRE REPRESENTAÇÕES SOCIAIS VJIRS, 5,3, 2007, Brasília. Anais...2007.

CHARLOT, Bernard. Da relação com o saber: elementos para uma teoria. Porto Alegre : Artmed, 2008.

CHARTIER, Roger. A aventura do livro: do leitor ao navegador. São Paulo: UNESP: Imprensa Oficial, 1999.

CHAUÍ, Marilena. Cultura e democracia: o discurso competente e outras falas. São Paulo: Cortez, 1989.

COBB, Roger W.; ELDER Charles D. Issues and agendas. In: THEODOULOU, Stella Z.; CAHN, Matthew A. Public policy: the essential readings. New Jersey: Prentice Hall, 1995. p. 96-104.

CURY, Carlos Roberto Jamil. Direito à educação: direito à igualdade, direito à diferença. Cadernos de Pesquisa, n. 116, jul.2002, p. 245-262. Disponível em: < http://www.scielo.br/pdf/cp/n116/14405.pdf>. Acesso em: 27 jan. 2014.

DE CERTEAU, Michel. A cultura no plural. Campinas: Papirus, 1995.

DEUBEL, André-Noël Roth. Políticas públicas: formulación, implementación y evaluación. Bogotá: Aurora, 2007.

FREY, Klaus. Políticas públicas: um debate conceitual e reflexões referentes à prática da análise de políticas públicas no Brasil. Planejamento e políticas públicas, n. 21, p. 211-259, jan. 2000.

GADOTTI, Moacir. Educação e poder: introdução à pedagogia do conflito. 16 ed. São Paulo: Cortez, 2012. 
GOMES, Sônia de Conti. Bibliotecas e sociedade na Primeira República. São Paulo: Pioneira, 1983.

GONZÁLEZ-SUÁREZ, Mirta. Psicologia política. San José: Editorial UCR, 2008.

GOULEMOT, Jean Marrie. O amor às bibliotecas. São Paulo: Unesp, 2011.

HEBRARD, Jean. As bibliotecas escolares: entre leitura pública e leitura escolar na França do II Império e da III República. Campinas: Mercado das letras, 2009.

HORTA, José Silvério Baia. Direito à educação e obrigatoriedade escolar. Cadernos de pesquisa, n. 104, p. 5-34, jul. 1998. Disponível em:

<http://www.fcc.org.br/pesquisa/publicacoes/cp/arquivos/158.pdf > Acesso em: 16 fev. 2014.

HOWLETT, Michael; RAMESH, M.; PERL, Anthony. Studying public policy: policy cicles e policy subsystems. 3. ed. Canadá: Oxford, 2009.

INSTITUTO NACIONAL DE ESTUDOS E PESQUISAS EDUCACIONAIS ANÍSIO TEIXEIRA (INEP). Censo escolar da educação básica 2012: resumo técnico. Brasília: INEP, 2013. Disponível em: <

http://download.inep.gov.br/educacao_basica/censo_escolar/resumos_tecnicos/resumo_tecnic o_censo_educacao_basica_2012.pd >. Acesso em: 27.01.2014.

INSTITUTO NACIONAL DE ESTUDOS E PESQUISAS EDUCACIONAIS ANÍSIO TEIXEIRA (INEP). Censo escolar: caderno de instruções. Brasília: INEP, 2012. Disponível em:

$<$ http://download.inep.gov.br/educacao_basica/censo_escolar/caderno_de_instrucoes/caderno _de_instrucoes_2012.pdf >. Acesso em : 27.01.2014.

JACOB, Christian. Prefácio. In: JACOB, Christian; BARATIN, Marc. O poder das bibliotecas: a memória dos livros no Ocidente. 3.ed. Rio de Janeiro: UFRJ, 2008. p.9-17.

KINGDON, John. Agendas, alternatives, and public policies. 2. ed. New York: Longman, 2003. (Longman classics in Political Science).

KINGDON, John. Como chega a hora de uma ideia? In: SARAVIA, Enrique; FERRAREZI, Elisabete. Políticas públicas: coletânea - volume 1. Brasília: ENAP, 2007. p.219-224.

LAJOLO, Marisa; ZILBERMAN, Regina. A formação da leitura no Brasil. 3.ed. São Paulo: Ática, 2003.

LAROSSA BONDIA, Jorge. Notas sobre a experiência e o saber de experiência. Revista Brasileira de Educação, n. 19, p.20-28, jan/abr 2002. Disponível em: <http://www.scielo.br/pdf/rbedu/n19/n19a02.pdf>. Acesso em: 08 jan. 2014.

LARROSA, Jorge; KOHAN, Walter. Apresentação da coleção. In: RANCIÈRE, Jacques. O mestre ignorante: cinco lições sobre a emancipação intelectual. 3.ed. Belo Horizonte: Autêntica, 2011. p.1.

LAZARTE, Leonardo. Ecologia cognitiva na Sociedade da informação. Ciência da Informação, Brasília, v. 29, n. 2, p. 43-51, maio/ago. 2000. 
LEFORT, Claude. Pensando o político: ensaios sobre democracia, revolução e liberdade. Rio de Janeiro: Paz e Terra, 1991.

LIMA, Antonio Bosco de. Estado, políticas públicas e educação no Brasil. In: LUCENA, Carlos (Org.). Capitalismo, Estado, Educação. Campinas:Alínea, 2008. p. 133-150.

MARCÍLIO, Maria Luiza. História da escola: em São Paulo e no Brasil. São Paulo: Imprensa oficial, 2005.

MARTINS, Wilson. A palavra escrita: história do livro, da imprensa e da biblioteca. São Paulo: Ática, 1996.

MEDELLÍN TORRES, Pedro. La política de las políticas públicas: propuesta teórica y metodológica para el estudio de las políticas públicas en países de frágil institucionalidad. Santiago de Chile: CEPAL, 2004. (Políticas sociales).

MINISTÉRIO DA EDUCAÇÃO (MEC). Avaliação de bibliotecas escolares no Brasil. Brasília: MEC, 2011.

MINISTÉRIO DA EDUCAÇÃO (MEC). PNLD. 2013. Disponível em: $\langle$ http://portal.mec.gov.br/index.php?Itemid=668id=12391option=com_contentview=article $>$. Acesso em: 27.01.2014.

MOKATE, Karen Marie. Convirtiendo el "monstruo" en aliado: la evaluación como herramienta de la gerencia social. Revista do Serviço Público, Brasília, v. 53, n. 1, p. 89-131, jan./mar. 2002.

MORAES, Rubens Borda de. Livros e bibliotecas no Brasil colonial. Brasília: Briquet de Lemos, 2006.

MORIN, Edgar. Os sete saberes necessários à educação do futuro. 2.ed. São Paulo: Cortez; Brasília: Unesco, 2000.

NOGUEIRA, Marco Aurélio. Um estado para a sociedade civil: temas éticos e políticos da gestão democrática. São Paulo: Cortez, 2004.

OLIVEIRA, Daniela Piergili Weiers. Políticas públicas de fomento à leitura: agenda governamental, política nacional e práticas locais. 2011. Dissertação (Mestrado em Administração Pública e Governo) - Escola de Administração de Empresas, Fundação Getúlio Vargas, São Paulo, 2011. Disponível em: < http://bibliotecadigital.fgv.br/dspace/bitstream/handle/10438/8248/62090100021.pdf?sequenc $\underline{\mathrm{e}=1}>$ Acesso em 06 jul. 2014.

OLIVEIRA, Lúcia Maciel Barbosa de. Participação: para pensar políticas culturais no século XXI. Políticas Culturais em Revista, v. 1, n. 3, p. 93-101, 2010. Disponível em: <www.politicasculturaisemrevista.ufba.br>. Acesso em: 07 jul. 2014.

PAIVA, Jane; BERENBLUM, Andréa. Programa Nacional Biblioteca da Escola (PNBE): uma avaliação diagnóstica. Pro-Posições, Campinas, v. 20, n. 1 (58), p. 173-188, jan./abr. 
2009. Disponível em: <http://www.scielo.br/pdf/pp/v20n1/v20n1a10>. Acesso em: 24 fev. 2014.

PERROTTI, Edmir (Org.). Cadernos REBI: rede escolar de bibliotecas interativas. São Bernardo do Campo: SEC, 2007.

PERROTTI, Edmir. Olhando a significação: do paradigma do acesso ao da apropriação da informação. In: MARTELETO, Regina Maria; STOTZ, Eduardo Navarro (Org.).

Informação, saúde e redes sociais: diálogos de conhecimentos nas comunidades da Maré. Rio de Janeiro : Fiocruz Belo Horizonte: UFMG, 2009. p.13.

PERROTTI, Edmir; PIERUCCINI, Ivete. Infoeducação: saberes e fazeres da contemporaneidade. In: LARA, M. L. G, FUJINO, A. NORONHA, D. P. (Orgs.) Informação e contemporaneidade: perspectivas. Recife: Néctar, 2008. p. 46-97. Disponível em: < http://www.pos.eca.usp.br/sites/default/files/file/cienciaInformacao/informacaoContemporani edade.pdf > Acesso em: 28 jul. 2013.

PERROTTI, Edmir; PIERUCCINI, Ivete. Novos saberes para o século XXI. In:

MENDONÇA, R.H.; MARTINS, M. F. (Orgs.). Novos saberes para a Educação. Rio de Janeiro : ACERP ; Brasília, DF : TV Escola, 2013. (TV, educação e formação de professores: salto para o futuro 20 anos, 4). p. 9-25. Disponível em:

<http://tvescola.mec.gov.br/images/stories/publicacoes/salto_para_o_futuro/salto_20_anos/vo 1_4_salto_para_o_futuro_20_anos.pdf> . Acesso em: 20 fev. 2014.

PIERUCCINI, Ivete. A ordem informacional dialógica: estudo sobre a busca de informação em educação. 2004. Tese (Doutorado em Ciência da Informação) - Escola de Comunicações e Artes, Universidade de São Paulo, São Paulo, 2004.

PIERUCCINI, Ivete. Sistema documentário da biblioteca escolar interativa - BEI. In: PERROTTI, Edmir (Org.). Cadernos REBI: rede escolar de bibliotecas interativas. São Bernardo do Campo: SEC, 2007.

PIERUCCINI, Ivete; PERROTTI, Edmir. Biblioteca escolar: da superação do empirismo à infoeducação. In: FÓRUM DE PESQUISA EM BIBLIOTECA ESCOLAR, 1., 2012, Belo Horizonte. Anais... Belo Horizonte: UFMG, 2012, p. 9-27.

RANCIÈRE, Jacques. O mestre ignorante: cinco lições sobre a emancipação intelectual. 3.ed. Belo Horizonte: Autêntica, 2011. (Educação: experiência e sentido).

RODRIGUES, Marta M. Assumpção. Políticas públicas. São Paulo: Publifolha, 2011. (Folha explica).

RUSSELL, Bertrand. O elogio ao ócio. Rio de Janeiro: Sextante, 2002.

SARAVIA, Enrique. Introdução à teoria da política pública. In: SARAVIA, Enrique; FERRAREZI, Elisabete. Políticas públicas: coletânea - volume 1. Brasília: ENAP, 2007. p.21-42.

SCHWARTZMAN, Simon; BOMENY, Helena Maria Bousquet; COSTA, Vanda Maria Ribeiro. Tempos de Capanema. São Paulo: Edusp; Rio de Janeiro: Paz e terra, 1984. 
SECCHI, Leonardo. Políticas públicas: conceitos, esquemas de análise, casos práticos. São Paulo: Cengage Learning, 2011.

SELLTIZ, Claire et al. Métodos de pesquisa nas relações sociais. São Paulo: Epu, 1975.

SEN, Amartya. Desenvolvimento como liberdade. São Paulo: Companhia das Letras, 2005.

SIDNEY, Mara S. Policy formulation: design and tools. In.: FISCHER, Frank; MILLER,

Gerald J.; SIDNEY, Mara S. (Ed.). Handbook of public policy: theory, politics and methods. Boca Raton: CRC Press, 2007. p. 79-87.

SILVA, Waldeck Carneiro da. Miséria da biblioteca escolar. São Paulo: Cortez, 1999.

SOUZA, Celina. Estado da arte na pesquisa em políticas públicas. In: HOCHMAN, Gilberto; ARRETCHE, Marta; MARQUES, Eduardo (Org.). Políticas públicas no Brasil. Rio de Janeiro: Fiocruz, 2010.p. 65-86.

TARALLI, Cibele Haddad. Espaço, mobiliário e comunicação visual. In: PERROTTI, Edmir (Org.). Cadernos REBI: rede escolar de bibliotecas interativas. São Bernardo do Campo: SEC, 2007.

TEIXEIRA COELHO, José. Dicionário crítico de política cultural: cultura e imaginário. 3. Ed. São Paulo: Iluminuras, 2004.

THEODOULOU, Stella. The contemporary language of public policy: a starting point. In: THEODOULOU, Stella Z.; CAHN, Matthew A. Public policy: the essential readings. New Jersey: Prentice Hall, 1995. p.1-10.

TOURAINE, Alain. O que é a democracia?Petrópolis: Vozes, 1996.

VIDAL, Diana Gonçalves. Bibliotecas escolares: experiências escolanovistas nos anos de 1920 e 1930. In:MENEZES, Maria Cristina (Org.). Educação, memória, história: possibilidades, leituras. Campinas: Mercado das letras, 2004.

VIDAL, Diana Gonçalves. Livros por toda parte: o ensino ativo e a racionalização da leitura nos anos de 1920 e 1930 no Brasil. In: ABREU, Márcia (Org.). Leitura, história e história da leitura. Campinas: Mercado das letras, 2002. p. 335-355. 


\section{APÊNDICES}

\section{APÊNDICE A - Roteiro de entrevistas semiestruturadas referentes à Lei Federal $\mathrm{n}^{0} 12.244 / 10$}

\begin{tabular}{|c|c|}
\hline $\begin{array}{c}\text { PERFIL DO } \\
\text { ENTREVISTADO } \\
\end{array}$ & ROTEIRO DE ENTREVISTA SEMIESTRUTURADA \\
\hline $\begin{array}{l}\text { Atual presidenta do } \\
\text { CFB }\end{array}$ & $\begin{array}{l}\text { - Comente as ações do CFB em torno da garantia da biblioteca escolar no país. } \\
\text { - Houve pressão por parte da população demandando biblioteca escolar que tenha culminado na } \\
\text { ação do Conselho em defesa desta instituição?Qual a concepção de biblioteca escolar adotada e } \\
\text { implementada pela política? } \\
\text { - Como se deu (e se dá) a participação do CFB em busca da criação e efetivação dos } \\
\text { desdobramentos da lei n. 12244/10? } \\
\text { - Quais elementos culminaram na criação da lei n. } 12244 / 10 \text { (cenário político favorável, pressão } \\
\text { de determinados segmentos sociais, grupos de interesse, categorias profissionais, dentre outros)? } \\
\text { - Como o CFB encara as disposições da lei (viabilidade, pontos fortes, fracos)?As escolas foram } \\
\text { receptivas à proposta? } \\
\text { - O CFB tem conhecimento de ações sendo desenvolvidas em torno da efetivação da lei } \\
\text { 12.244/10?Foram delineados critérios para avaliar os resultados da política pública? } \\
\text { - O que acredita ser preciso para que a intenção disposta em lei transforme-se em ação?Alterações } \\
\text { na gestão municipal influenciaram na proposta inicial e no funcionamento da REBI? } \\
\text { Como o CFB encara o PL28/2012 que isenta o setor privado de ensino da obrigatoriedade de } \\
\text { criar bibliotecas escolares?Há alguma pessoa que teve participação ativa neste processo e seria } \\
\text { relevante entrevistar? }\end{array}$ \\
\hline $\begin{array}{l}\text { Presidenta do CFB } \\
\text { entre os anos de } 2006 \\
\text { e } 2012\end{array}$ & $\begin{array}{l}\text { - Quais os atores (políticos, grupos de interesse, organizações etc.) que atuaram em prol da criação } \\
\text { da lei n. } 12244 / 10 \text { ? } \\
\text { - Como vê o cenário de surgimento da lei (facilidades, dificuldades, jogadas políticas)? } \\
\text { - Como encara as disposições da lei (viabilidade, pontos fortes, fracos)? } \\
\text { - Comente os antecedentes que desencadearam a criação da lei n. 12244/10, explicitando se houve } \\
\text { pressão de segmentos sociais, participação da população, consensos, ações que implicaram na } \\
\text { mobilização do CFB. } \\
\text { - Como se deu (e se dá) a participação do CFB em busca da criação e efetivação dos } \\
\text { desdobramentos da lei n. } 12244 / 10 \text { ? } \\
\text { - Praticamente } 3 \text { anos após o surgimento da lei, quais ações são desdobramentos desta? } \\
\text { - Há um projeto em andamento (Projeto de Lei da Câmara 28/2012.) que propõe alterar a } \\
\text { obrigatoriedade - explicitada na lei n. 12244, da existência de um bibliotecário em cada escola. } \\
\text { Como você vê essa proposta? } \\
\text { Estou conversando com a senhora, que foi presidente do CFB para ouvir a opinião desse grupo } \\
\text { de interesse. Há alguém na esfera política que a senhora poderia me indicar como figura } \\
\text { relevante no processo de criação da lei } 12.244 \text { para que eu tente contato, caso seja necessário? }\end{array}$ \\
\hline $\begin{array}{l}\text { Professor } \\
\text { universitário no } \\
\text { bacharelado em } \\
\text { Biblioteconomia da } \\
\text { ECA/USP. } \\
\text { Presidente do CFB } \\
\text { entre os anos de } 2000 \\
\text { e } 2002 \text { e também do } \\
\text { CRB8 entre os anos } \\
\text { de } 1991 \text { e } 1993 \text {. }\end{array}$ & $\begin{array}{l}\text { - Comente os antecedentes que desencadearam a criação da lei n. } 12244 / 10 \text {, explicitando se houve } \\
\text { - } \quad \text { Quais os atores (políticos, grupos de interesse, organizações etc.) que atuaram em prol da criação } \\
\text { da lei n. } 12244 / 10 \text { ? } \\
\text { - Houve pressão por parte da população demandando biblioteca escolar que tenha culminado na } \\
\text { mobilização dos Conselhos } \\
\text { - Como encara as disposições da lei } 2.244 / 10 \text {. Acredita ser viável a implantação de bibliotecas no } \\
\text { prazo estipulado? } \\
\text { - Como encara o conceito de biblioteca escolar que consta na lei } 12.244 / 10 \text { ? } \\
\text { - Como encara as disposições do PL28/2012? }\end{array}$ \\
\hline
\end{tabular}




\section{APÊNDICE B - Redes de bibliotecas escolares identificadas no território nacional}

A partir de levantamento na web, contato com os Conselhos Regionais de Biblioteconomia, com a atual presidente do Conselho Federal de Biblioteconomia -Regina Celi de Sousa -, bem como com a Profa. Dra. Bernardete Campello, elencamos a existência de redes de bibliotecas escolares nas seguintes cidades:

- São Bernardo do Campo: tendo início em 1999, atualmente a Rede escolar de bibliotecas interativas (REBI) é constituída por 91 bibliotecas escolares interativas e 44 espaços adequados (espaços que não possuem as mesmas características físicas das bibliotecas escolares interativas). ${ }^{42}$

- Londrina: em 2001, a partir de projeto específico, deu-se a criação de uma efetiva Rede de bibliotecas escolares da prefeitura do município de Londrina, que conta com 75 bibliotecas ${ }^{43}$.

- Curitiba: implantada em 2005, a Rede de bibliotecas escolares de Curitiba conta com 143 bibliotecas escolares e 47 Faróis do saber (bibliotecas comunitárias que funcionam em apoio às escolas municipais e como pontos de referência cultural e de lazer para a comunidade) ${ }^{44}$.

- Belo Horizonte: em 1997, sob coordenação do Núcleo de Coordenação de Bibliotecas, teve início o Programa de Revitalização das Bibliotecas Escolares - atual Programa de Bibliotecas - que abrange 181 escolas, cada uma delas com uma biblioteca. ${ }^{45}$

- Fortaleza $^{46}$

- Goiânia $^{47}$

42 Informações obtidas em : < http://www.educacao.saobernardo.sp.gov.br/index.php/bibliotecasescolares >. Acesso em: 30 jun. 2013.

${ }^{43}$ Informações obtidas em: DI CHIARA, Ivone Guerreiro; BORTOLIN, Sueli. Experiências em bibliotecas escolares de Londrina - Paraná. In: FÓRUM DE PESQUISA EM BIBLIOTECA ESCOLAR, 1, 2012. Belo Horizonte. Anais eletrônicos...Belo Horizonte: UFMG, 2012. Disponível em: < http://gebe.eci.ufmg.br/index.php?option=com_content\&view=article\&id=101\&Itemid=90>Acesso em: 30 jun. 2013.

${ }^{44}$ Informações obtidas em: <http://cidadedoconhecimento.org.br/cidadedoconhecimento/index.php?subcan=12 $>$. Acesso em: 30 jun. 2013.

${ }^{45}$ Informações obtidas em: MORAIS, Elaine Maria. Impasses e possibilidade da atuação dos profissionais das bibliotecas da rede municipal de Belo Horizonte. 2009. Mestrado (Educação) - Universidade Federal de Minas Gerais, Belo Horizonte, 2009. Disponível em: < (http://www.bibliotecadigital.ufmg.br/dspace/handle/1843/FAEC-84KPUC >. Acesso em: 30 jun. 2013.

${ }^{46}$ Não foram encontradas informações sobre quantidade de bibliotecas escolares e início da rede em Fortaleza.

${ }^{47}$ Não foram encontradas informações sobre quantidade de bibliotecas escolares e início da rede em Goiânia. 


\section{APÊNDICE C - Roteiro de entrevistas semiestruturadas referentes à REBI}

\begin{tabular}{|c|c|}
\hline $\begin{array}{c}\text { PERFIL DO } \\
\text { ENTREVISTADO }\end{array}$ & ROTEIRO DE ENTREVISTA SEMIESTRUTURADA \\
\hline $\begin{array}{l}\text { Profissionais } \\
\text { técnico- } \\
\text { especializados que } \\
\text { participaram da } \\
\text { implementação } \\
\text { gestão da REBI }\end{array}$ & $\begin{array}{l}\text { - } \quad \text { Qual sua relação com a REBI? } \\
\text { - } \quad \text { Como surge a REBI e qual a intenção com sua criação? } \\
\text { - } \quad \text { Qual o(s) ator(s) político(s) que efetivamente tomou a decisão pela implantação da REBI? } \\
\text { - } \quad \text { Qual a concepção de biblioteca escolar adotada e implementada pela política? } \\
\text { - } \quad \text { Qual a estrutura inicial da Rede? } \\
\text { - } \quad \text { Como se deu a implantação das bibliotecas escolares? } \\
\text { - } \quad \text { O comunidade (pais, alunos, moradores do entorno) participou de alguma forma do processo? } \\
\text { - } \quad \text { escolares? } \\
\text { - } \quad \text { Como a comolas foram a política pública acerca de recursos humanos e materiais para as bibliotecas } \\
\text { - } \quad \text { Foram delineados critérios para avaliar os resultados da política pública? } \\
\text { - } \quad \text { Alterações na gestão municipal influenciaram na proposta inicial e no funcionamento da REBI? } \\
\text { - } \quad \text { Inicialmente foram desenvolvidas } 5 \text { bibliotecas. Atualmente há 91. Como percebe tal expansão? } \\
\text { - Há alguma pessoa que teve participação ativa neste processo e seria relevante entrevistar? }\end{array}$ \\
\hline $\begin{array}{l}\text { Professor de Apoio } \\
\text { à Biblioteca Escolar } \\
\text { (REBI) }\end{array}$ & $\begin{array}{l}\text { - } \quad \text { Qual sua relação com a REBI na época em que surge? } \\
\text { - } \quad \text { Como foi a expansão da REBI? O que favoreceu essa expansão? } \\
\text { - } \quad \text { Como era e como funcionava uma biblioteca da REBI no momento da sua criação? O que foi mais } \\
\text { - } \quad \text { Comorcante/importante? } \\
\text { - } \quad \text { A PABE foi uma inovação no conceito de biblioteca da REBI? Qual era o papel da PABE e qual o } \\
\text { - } \quad \text { A PApel dela hoje? } \\
\text { - Qual era a relação entre a PABE e os demais educadores da escola? } \\
\text { - O que significou a retirada da PABE das bibliotecas? } \\
\text { - As BEIs hoje continuam com o mesmo papel que tiveram no início da criação da REBI? Por quê? } \\
\text { - Na sua opinião, o que ocasionou mudanças na REBI? }\end{array}$ \\
\hline $\begin{array}{lr}\text { Mentor intelectual e } \\
\text { assessor } & \text { da } \\
\text { implantação } & \text { da } \\
\text { REBI } & \end{array}$ & $\begin{array}{l}\text { - Como surgiu a parceria entre a USP e a prefeitura de São Bernardo do Campo para a criação da } \\
\text { REBI? } \\
\text { - } \quad \text { Qual o conceito de biblioteca escolar proposto para a ação política? Ao longo da implantação esse } \\
\text { - Conceito se alterou? } \\
\text { - Como as escolas receberam as BEIs? } \\
\text { - } \quad \text { Os quadros profissionais da Educação se apropriaram da REBI? }\end{array}$ \\
\hline $\begin{array}{lr}\text { Prefeito } & \text { que } \\
\text { implementou } & \text { a } \\
\text { política pública que } \\
\text { criou a REBI }\end{array}$ & $\begin{array}{l}\text { - O sr. Pode contar como se deu a criação das bibliotecas escolares, em SBC, a partir do final dos } \\
\text { - } \quad \text { Comos } 90 \text { (1999)? } \\
\text { - } \quad \text { O surgimento da REBI está relacionado a transformações no amplo contexto da Educação ocorrido } \\
\text { - } \quad \text { Com São Bernardo do Campo se deu a parceria com a universidade que orientou a criação das bibliotecas? } \\
\text { - } \quad \text { Inicialmente foram criadas } 6 \text { bibliotecas, que constituíram a REBI. O que motivou a expansão da } \\
\text { - } \quad \text { Quais as dificuldades encontradas para a implantação da REBI? Houve oposição de algum setor? } \\
\text { - Como foi contornado? Houve apoio de setores? Como foi obtido e alimentado? } \\
\text { - } \quad \text { Como longo de sua gestão, houve alterações na política pública para as bibliotecas escolares? } \\
\text { bibliotecas/REBI para SBC? Quais resultados acredita terem sido alcançados com a criação da } \\
\text { - REBI? } \\
\text { As mudanças na gestão municipal repercutiram na política para bibliotecas? Como? Por quê? } \\
\text { O que acredita ser preciso para que uma política pública para bibliotecas escolares seja perene, não }\end{array}$ \\
\hline
\end{tabular}




\begin{tabular}{|c|c|}
\hline & sofrendo rupturas com alterações na gestão municipal? \\
\hline $\begin{array}{l}\text { Secretário de } \\
\text { Educação e Cultura } \\
\text { da implementação } \\
\text { da REBI }\end{array}$ & 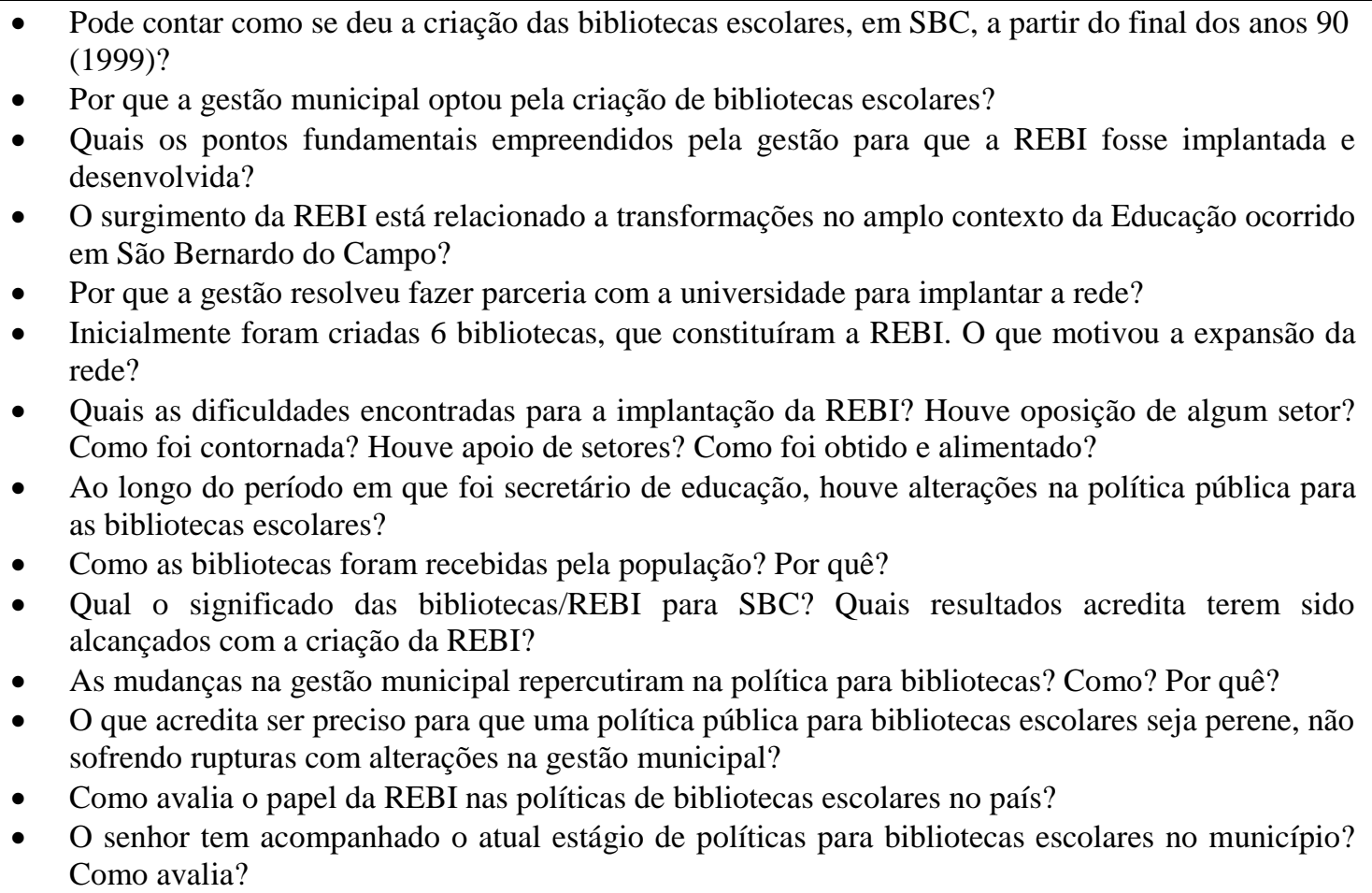 \\
\hline
\end{tabular}




\section{ANEXOS}

ANEXO A - Lei Federal n 12.244, de 24 de maio de 2010

\section{LEI N 12.244 DE 24 DE MAIO DE 2010.}

\section{Dispõe sobre a universalização das bibliotecas nas instituições de ensino do País.}

O PRESIDENTE DA REPÚBLICA Faço saber que o Congresso Nacional decreta e eu sanciono a seguinte Lei:

Art. $1^{\circ}$ As instituições de ensino públicas e privadas de todos os sistemas de ensino do País contarão com bibliotecas, nos termos desta Lei.

Art. $2^{\circ}$ Para os fins desta Lei, considera-se biblioteca escolar a coleção de livros, materiais videográficos e documentos registrados em qualquer suporte destinados a consulta, pesquisa, estudo ou leitura.

Parágrafo único. Será obrigatório um acervo de livros na biblioteca de, no mínimo, um título para cada aluno matriculado, cabendo ao respectivo sistema de ensino determinar a ampliação deste acervo conforme sua realidade, bem como divulgar orientações de guarda, preservação, organização e funcionamento das bibliotecas escolares.

Art. $3^{\circ}$ Os sistemas de ensino do País deverão desenvolver esforços progressivos para que a universalização das bibliotecas escolares, nos termos previstos nesta Lei, seja efetivada num prazo máximo de dez anos, respeitada a profissão de Bibliotecário, disciplinada pelas Leis nos 4.084, de 30 de junho de 1962, e 9.674, de 25 de junho de 1998.

Art. $4^{\circ}$ Esta Lei entra em vigor na data de sua publicação.

Brasília, 24 de maio de 2010; $189^{\circ}$ da Independência e $122^{\circ}$ da República.

\section{LUIZ INÁCIO LULA DA SILVA}

Fernando Haddad

Carlos Lupi 


\title{
ANEXO B - Projeto de lei $\mathbf{n}^{0} \mathbf{1 . 8 3 1}$, de 2003
}

\section{PROJETO DE LEI N ${ }^{\circ}$ 1.831, DE 2003 \\ (Do Sr. Lobbe Neto)}

\author{
Dispõe sobre a universalização \\ das bibliotecas nas instituições de \\ ensino do País.
}

O Congresso Nacional decreta:

Art. $1^{\circ}$ As instituições de ensino públicas e privadas de todos os sistemas de ensino do País contarão com bibliotecas, nos termos desta Lei.

Art. $2^{\circ}$ Para os fins desta lei, considera-se biblioteca a coleção de livros, materiais videográficos e documentos congêneres destinados a estudo, consulta ou leitura recreativa, com um acervo mínimo de quatro livros por aluno matriculado.

Parágrafo único. Compete a cada sistema de ensino determinar a ampliação deste acervo mínimo conforme sua realidade, bem como divulgar orientação de guarda, preservação, organização e funcionamento das bibliotecas escolares.

Art. $3^{\circ}$ Os sistemas de ensino do País e a União, no exercício de sua função supletiva, deverão desenvolver esforços progressivos para que a universalização das bibliotecas escolares, nos termos previstos nesta Lei, seja efetivada no prazo máximo de cinco anos.

Art. $4^{\circ}$ Esta lei entra em vigor na data de sua publicação.

\section{JUSTIFICAÇÃO}

O projeto que ora reapresentamos, foi apresentado no ano de 2000, pela nobre ExDeputada Federal Esther Grossi e tendo substitutivo apresentado pelo Dep. Osmar Serraglio, membro da CCJR, da Câmara dos Deputados, no ano de 2001, sendo que os seus princípios básicos constituem importância ímpar, no momento, em que as Bibliotecas Brasileiras encontram-se com seus acervos sem renovações há muitos anos.

É função da Escola, como instituição cultural, abrir horizontes, valorizando como um de seus lugares mais importantes, o armário, ou sala, onde estão disponíveis os livros considerando como agentes civilizatórios de formação e de difusão cultural. Este projeto de lei pretende ampliar a discussão e dar consistência ao ato de aprender a ler pois só com a leitura de livros ingressamos, de fato, num mundo que é muito mais vasto e instigante que nosso horizonte pessoal.

Propomos para este início de universalização das Bibliotecas Escolares o acervo mínimo de quatro livros por aluno matriculado. A proporção proposta pela Associação Americana de Bibliotecas (USA), é de dez livros por aluno, quociente que aumentaria nas 
escolas de matrícula mais reduzida. A diferença nas propostas, lá e aqui, já demonstra nossa defasagem para com os fatos da educação e da cultura.

Outra informação importante que justifica esse projeto de lei é a fornecida pelos dados do Sistema Nacional de Avaliação da Educação Básica - SAEB, que, analisando os dados obtidos com a aplicação de provas para os alunos e questionários para professores e diretores em 1997, concluiu que os alunos estudantes de escolas equipadas com biblioteca alcançam maior rendimento.

A nada chegaremos como pessoas e como nacionalidade, sem conhecimentos, que se fundamentam, ampliam e renovam, pela informação. Cabe a esta geração a responsabilidade de criar uma biblioteca em cada escola, em todos os recantos geográficos e em todos os "Brasis", abrindo para cada aluno a janela mágica do conhecimento, a oportunidade de maravilhar-se, de desejar e de vir-a-ser, encontrando caminhos novos e mais ousados, como cidadãos informados, lúcidos e atuantes. Tudo isto nos reservam as Bibliotecas Escolares que multiplicaremos, até a totalidade de nossas escolas, com a aprovação desta lei.

Sala das Sessões, de agosto de 2.003.

Deputado Lobbe Neto 